\title{
LAS NAVAJAS
}

\section{Un Estudio y una Colección}

\author{
por
}

RAFAEL MARTINEZ DEL PERAL FORTON 


\section{A Carlos Martínez-Barbeito, maestro y compañero excepcional, decidido amante de las cosas bellas e impulsor entusiasta de este trabajo.}

EL AUTOR 


\section{Introducción}

El hecho de que mi padre fuera natural de Albacete, el que yo pasara desde mi primera infancia gran parte de la época estival en una pequeña aldea de San Clemente, la hermosa navaja manchega que en mi adolescencia me fue regalada en una célebre feria de Honrubia y mi decidida vocación de cazador, considero que son los hechos y las causas remotas en los que hay que buscar mi natural y latente afición a estas armas blancas españolas, $\tan$ útiles, $\tan$ populares, $\tan$ nobles, $\tan$ bellas.

Años después, muchos años después, una navaja típica española (Cat. núm. 1), que adquirí por poco dinero en Valencia, habría de ser la chispa que prendería sin remedio esa enorme hoguera que es mi afición a las navajas antiguas, y que durante este último lustro ha llenado con plenitud mis ratos de ocio y ha hecho mi felicidad de muchas horas.

Recorría el Rastro, de Madrid, observaba con minuciosidad los puestos callejeros, viajaba por los pueblos de Castilla, compraba nuevas piezas, las limpiaba, clasificaba y guardaba con gran amor y cuidado, las miraba continuamente y hasta las acariciaba. Pero la tenaz recomendación de mi gran amigo Carlos Martínez-Barbeito y Morás me empujó sin remedio a publicar el Catálogo de esta incipiente colección y a redactar unas cuantas notas, fruto de mis arduas pero apasionantes investigaciones aquí y allá.

$\mathrm{Ni}$ que decir tiene que con este breve trabajo lo que el autor pretende es tan sólo y en primer lugar aportar su humilde grano de arena a la historia de esta industria de tanta raigambre española, y en segundo lugar, a crear en gentes más capaces la suficiente inquietud para que se animen a completar y perfeccionar lo que aquí con la mejor voluntad e ilusión, pero con manifiestas deficiencias y muchas dificultades, he recogido para mis amigos los lectores. 


\section{Rehabilitación de la navaja}

Hablar de la navaja es, por sorprendente que ello pudiera parecer a algunos, hablar de algo que durante centurias ha formado parte integrante del español. Todos, el pobre y el rico, el hombre de campo y el de la ciudad, el viejo y el joven, tenían su propia navaja, que siempre lucían con orgullo.

La navaja llegó a convertirse en algunas comarcas en un auténtico símbolo, hasta tal punto que en un cuadro de Medina Vera titulado Costumbres regionales se ve cómo un padre hace entrega solemne a su hijo de una navaja como signo familiar e incluso social de haber alcanzado este último su mayoría de edad. Pero dejemos que aquel de quien yo aprendí tal costumbre ${ }^{\prime}$ nos hable con mayor detalle de algo primitivo que aún sobrevive: «En la parte oriental de Almetía, en la zona de Vera, Cuevas, etc., e internándose luego en el campo de Cartagena, por la parte de Aguilas, hubo, hasta los primcros años de este siglo, con bastante intensidad, la curiosísima costumbre "de la faca". Cuando el hijo del minero cumplía dieciocho años, su padre le entregaba, solemnemente, la faca. Era algo así como "armarle caballero". Antes de recibir la faca, iya se guardaría el muchacho de tener novia, de fumar ni de salir de noche! Una vez recibida era hombre independiente.

"Se hacía en una fiesta de alto interés. Primero, un gran baile, al que acudían todas las muchachas. Se bebía, había alegría y a la mitad del baile se ponían de pie el padre y el hijo. Se descubrían todos. El padre sacaba la faca, hacía una cruz con ella y le decía: "Hijo mío, te entrego la faca. Esta faca rondó a tu madre cuando la pretendí. No ha matado a nadie, pero me ha hecho respetar. Que Dios quiera que cumplas como hombre, como cumplieron tus abuelos y como cumplió tu padre." El hijo juraba serlo, abrazaba a su padre y era una gran emoción que se aguaba en vino y castañuelas. Ya estaba armado. Era el espaldarazo. Aquella noche salía él de ronda con su guitarra, daba serenata a las muchachas y siempre venía con dos o tres copas de más.»

Y aun hoy, ¿quién cuando se habla de este tema no nos cuenta las excelencias de esa navaja que todavía conserva en casa, o que desapareció durante la guerra civil, o fue a parar a tal o cual pariente con motivo de la testamentaría familiar?

Lo que sucede es que, muy injustamente, la navaja ba tenido y tiene mala prensa. Se la acusa de ser un arma traidora propia de bellacos y

1 Junn Cuadrado Ruiz: Algunas curiosas supervivencias en la provincia de Almería, Crónica del II Congreso Arqueológico del Sudeste Español, Albacete, 1946, págs. 388 y 389 . 
gentes de mal vivir. Admitimos, por supuesto, que gentes de esta calaña hicieron de la navaja un uso indebido, la hicieron servir como instrumento de delito. Pero el que exista gente dispuesta a hacer un mal uso de un arma no quiere decir, ni mucho menos, que el arma en sí sea deleznable y criminal. ¿Por qué había de serlo? Siempre se cometieron delitos con espadas, sables, dagas, con pistolas, revólveres y escopetas de caza y a nadie se le ha ocurrido identificar el reprobable hecho con el cuerpo del delito.

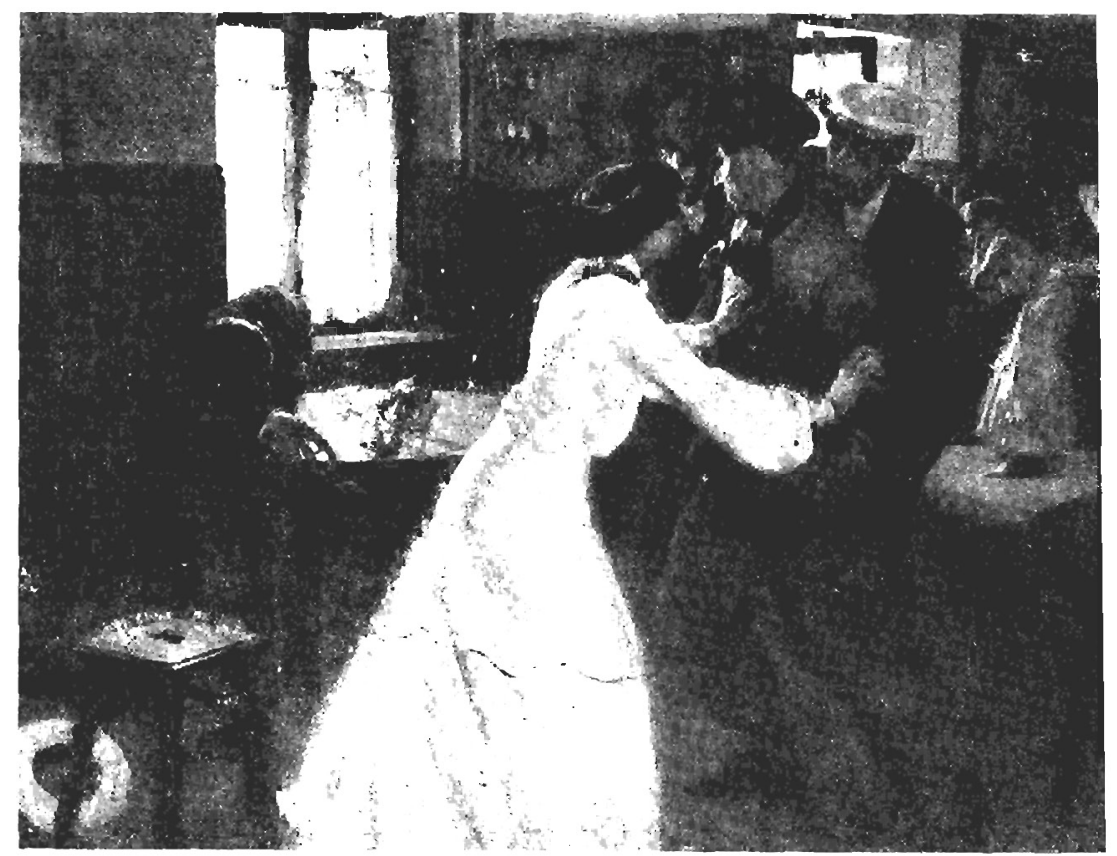

Fic. 1,-El Desquite. Cuadro de José Bermejo Sobera (Museo Español de Arte Contemporáneo, Madrid).

Por otro lado, el que ciertas personas portadoras de navajas cometan hechos reprobables en nada significa que todos sus usuarios sean gente criminal. El instrumento en sí es indiferente, nada presupone, como tampoco en el caso del coche, puesto que todos sabemos que los accidentes de automóvil ocasionan más muertos en un año que todos los homicidios voluntarios cometidos a golpe de navaja en una centuria. 
Por otra parte, si pensamos en el número de personas que poseen un arma de fuego y lo comparamos con el número de homicidios voluntarios cometidos con la misma, nos daremos cuenta de que este porcentaje es infinitamente superior al que se obtiene de comparar el número de personas que poscen una navaja y las muertes ocasionadas con esta arma blanca.

El duque de Tovar, buen amigo del que esto escribe, afirma en su libro Viajeros románticos por España ${ }^{2}$ que esa tan famosa inscripción de «No me saques sin razón ni me envaines sin honor» se escribía en la hoja de las espadas, arma noble, y jamás en las navajas, a las que califica, entre otras cosas, de plebeyas y populacheras. Pues bien: tal opinión es rigurosamente inexacta, pues esta leyenda es bastante frecuente, y yo mismo cuento en mi colección con algún bellísimo ejemplar de navaja (Cat. núm. 15; Fig. 12) en el que con absoluta claridad se puede todavía leer idéntica frase.

Al hablar de estos temas no podemos dejar de mencionar lo que dice el Diccionario geográfico-estadístico-bistórico de España y sus posesiones de ultramar ${ }^{3}$, de Pascual Madoz, que al comentar ciertas estadísticas sobre la criminalidad publicadas en 1843, cuando se refiere concretamente a Albacete, dice: «Quien oiga hablar de la provincia de Albacete, naturalmente se recuerda de las famosas fábricas de armas blancas de la capital y se persuadirá haber dado con el motivo del exceso que aparece de delitos de homicidio y de heridas, en la facilidad de adquirir instrumentos ofensivos; pero se verá precisado a abandonar esta idea luego que fije la vista en el mencionado estado y se convenza por él, que es casi insignificante la diferencia que resulta entre las cuatro provincias respecto a los delitos perpetrados con armas de fuego y blancas, ya de uso lícito, ya de ilícito, y advierta que si alguna existe es en favor de Albacete, donde relativamente es menor el número de delitos perpetrados con armas de toda especie que en las otras tres provincias (Murcia, Cuenca y Ciudad Real) y mayor el número de ofensas personales causadas con instrumentos contundentes, circunstancia que da por resultado: que si bien es cierto que el número de delitos es mayor proporcionalmente en Albacete, la gravedad de éstos es menor que en las provincias de Cuenca y Murcia, en las cuales supera el número de homicidios y heridas perpetradas con armas de fuego y blancas al de instrumentos contundentes.»

En el apartado en que hablamos de los usos de la navaja hemos recogido de forma más pormenorizada y casuística hasta qué punto este objeto era de uso general, necesario y hasta imprescindible. No vamos

${ }^{2}$ Madrid, 1971, pág. 365.

3 Tercera edición, Madrid, 1848, tomo I, pág. 251. 
ahora a insistir en ello, pero sí a recordar que en 1876 el Memorial literario decía que las navajas se habían hecho tan necesarias a los españoles como el propio pan, y M. de R., en su libro titulado Manual del baratero, $o$ arte de manejar la navaja, el cuchillo y la tijera de los gitanos ${ }^{4}$, dice: «La navaja es un arma usada generalmente en España por la clase trabajadora, y nos choca sobremanera esa aversión con que la miran los que pertenecen a clases más elevadas.»

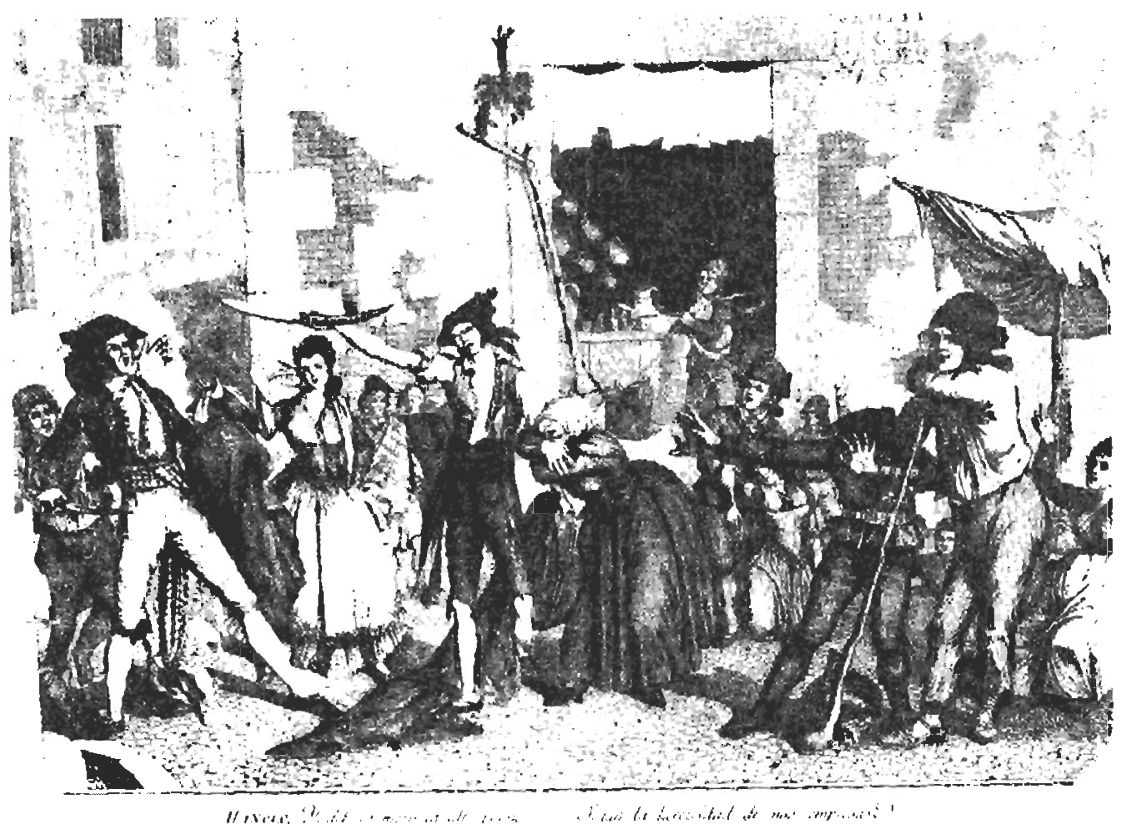

Fig. 2.-La úllima escena de «Manolo», sainete de don Ramón de la Cruz Cano y Olmedilla. Estampa anónima. $27,5 \times 20,5 \mathrm{~cm}$. Principios del siglo XIX (Museo Municipal de Madrid).

$$
R 2044 \text {. }
$$

Y más adelante: «La navaja, en fin, es el arma propia, como ya hemos dicho, de la clase trabajadora, del arriero, del trajinero, del artesano, del marinero, y un instrumento tan indispensable que muchos no pueden estar sin él.» El propio barón Charles Davillier, en su Viaje por España ${ }^{5}$,

+ Madrid, 1849, Imprenta de D. Alberto Goya, pág. 7.

'Ediciones Castilla, S. A., Madrid, 1949, pág. 120. 
escribe: «Albacete es en España lo que Châtellerault en Francia y Sheffield en Inglaterra. Las navajas, los cuchillos, los puñales se fabrican aquí a millares, cuchillería basta cuyo aspecto recuerda al de los trabajos árabes. La navaja es una de las cosas de España: entre las gentes del pueblo hay muy pocos que no lleven este cuchillo largo y afilado, ya en el bolsillo, ya en el cinturón y también atado por medio de una cuerda a los ojales de la chaqueta.» Richard Ford (1796-1858) ${ }^{6}$ señala: «En la faja se guarda la navaja, que forma parte integrante del español», y Teófilo Gautier ${ }^{7}$ afirma: "La navaja es el arma favorita de los españoles, sobre todo de la gente del pueblo.» Alejandro Luis Laborde ${ }^{8}$, a principios del siglo XIX —-cuando esta industria no era ni sombra de lo que había sido-, dice al referirse a Albacete: «Fabrícanse en esta villa muchas navajas y cuchillos de varias especies, calculándose anualmente al pie de 200.000 piezas...»

Finalmente, recogemos estos versos dados a la luz pública por Francisco Cutanda ${ }^{9}$ que hablan por sí solos de lo que la navaja ha representado en nuestro país:

Yo vi, en mi patria, cúmulo de males, faltar aire, luz, lechos, sepulturas, pan, paz, tierra, rocío y vejetales.

Sobrar pestes, contagios, desventuras, hambres, guerras, sequías y riadas, por todas sus vastísimas llanuras...

Mas jamás ocurrió ver agotadas, ni escasas de encontrar, ni encarecidas, ni en su lustre y virtud adulteradas.

Ni con menos primores guarnecidas ¡las navajas! ¡Por fin, piadoso cielo, que en esto de tu pueblo no te olvidas!

Vénse en humildes puestos por el suelo, en cestones, en cajas y arquillas, y en las tiendas colgadas por señuclo.

Véndense en los tinglados y casillas, véndense en los mercados, $\mathrm{y}$ en las ferias de las innobles y las nobles villas.

Tómanse, al caso, providencias sérias, porque el ámplio surtido no escasee, remedio á nuestras cuitas y miserias.

- Alfonso de Figueroa y Melgar (Duque de Tovar), op. cit., pág. 102.

7 Viaje por España, Editorial Mateu, Barcelona, 1971, pág. 205.

* Itinerario descriptivo de las provincias de España, Valencia, 1826, pág. 143.

- La Navaja, Madrid, 1856, Establecimiento Tipográfico de D. A. Vicente. 
Habrá quien, á las veces, titubee sobre encontrar del pan ó cl vino el puesto, no donde, en ellas, su dinero, emplee.

Libres son de alcabalas y de impuesto y janxás sucedió que, á las navajas afectara, el más alto presupuesto.

Horras y francas son estas alhajas, según nuestros constantes aranceles, que á cosas guardan su rigor, mas bajas...

Durante los años de nuestra posguerra, en que la escasez de alimentos y sobre todo de medios económicos para adquirirlos era general, recuerdo perfectamente cómo era frecuente escuchar en las gentes campesinas esa frase de «Pan y navaja» cuando alguien respondía a quien le preguntaba sobre lo que iba a cenar.

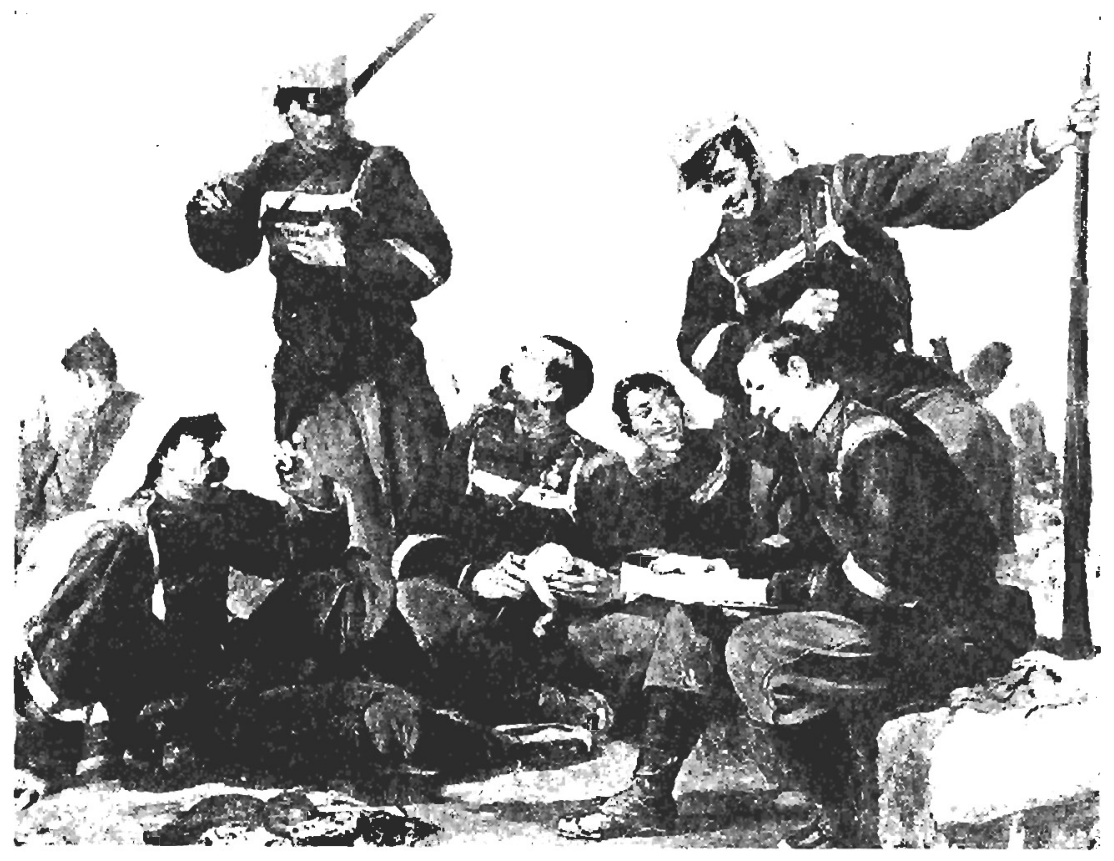

Fig. 3.— «El descanso en la marcha», cuadro de Juan Benlliure. Hacia 1870 (Museo de Bellas Artes de Valencia).

R. 2049 


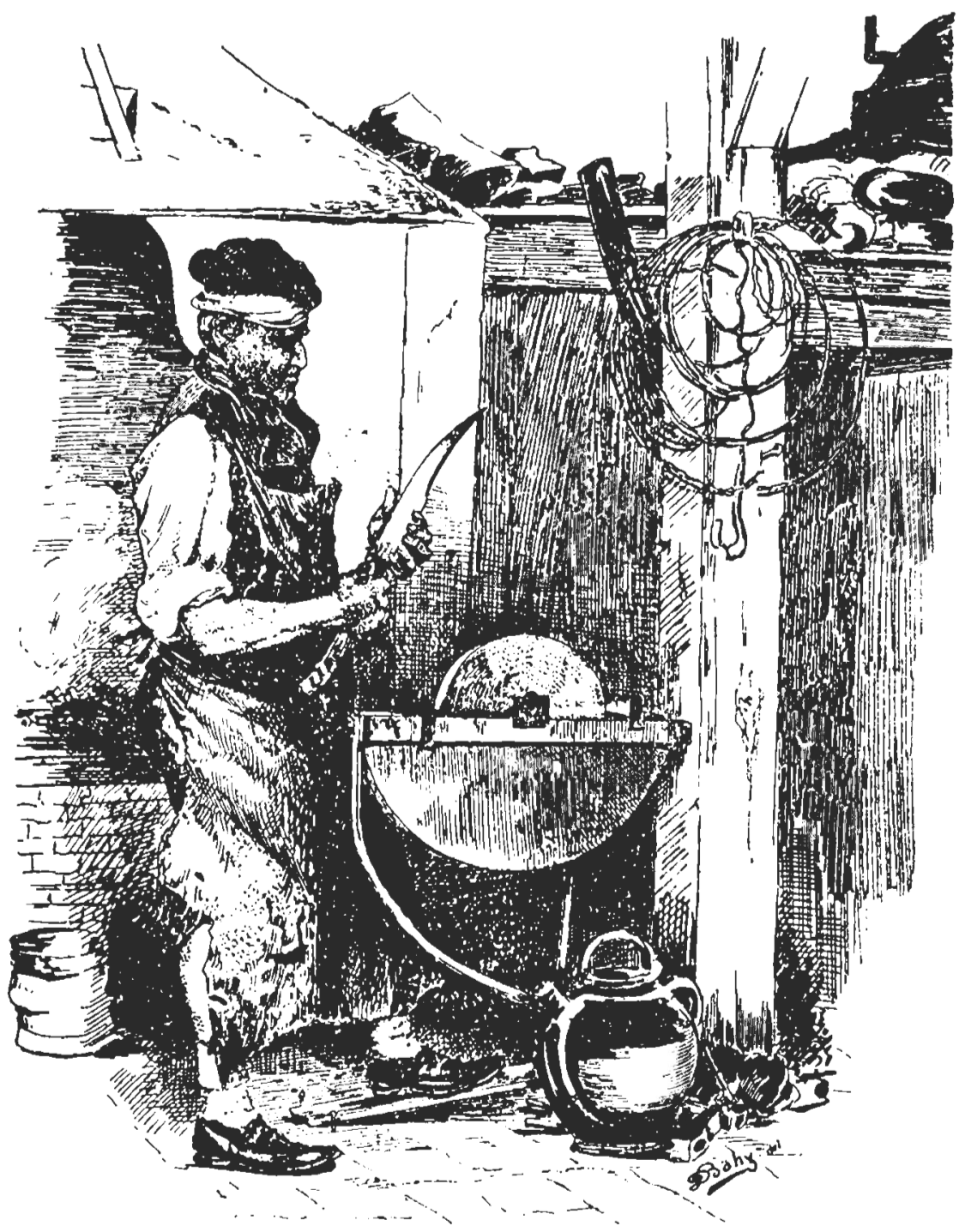

FIg. 4.- "Cuchillero español» (CAmIlle PaGÉ: La coutellerie depuis l'origine insau'i nos jours, t. VI, 1904, p. 1.280 bis).

R. 2046. 
Todavía hoy se conservan en muchas ciudades nombres de calles que recuerdan la raigambre e importancia de esta industria cuchillera. Así, es frecuente leer en las esquinas de ciertos barrios antiguos letreros indicativos de que nos encontramos en la calle de Las Armas, de Los Cuchilleros, de Los Dagueros, de Los Puñaleros, Tijereros, Navajeros o en algún callejón o travesía de la Ferrería o Cuchillería.

\section{Definición}

Nuestra Real Academia Española, en su decimoctava edición del Diccionario de la Lengua Española ${ }^{10}$, define la navaja como «cuchillo cuya hoja puede doblarse sobre el mango para que el filo quede guardado entre dos cachas o en hendidura a propósito».

La Enciclopedia Espasa, en su tomo 37, recoge la misma definición de la Academia de la Lengua, con la sola diferencia de que sustituye, acertadamente, la palabra doblarse por la de girar.

Enrique Leguina y Vidal, Barón de la Vega de Hoz, en su Glosario de Voces de Armería" , define la navaja como «hoja corta de un filo que se dobla y guarda en su mango».

Haciendo prosa de los versos de Francisco Cutanda, podemos decir que para él navaja es una hoja cortante y puntiaguda que gira sobre un mango gracias a un clavo remachado y que va provista de un fuerte muelle que la mantiene firme cuando está abierta.

Si éstas son las definiciones más autorizadas que sobre la navaja se han dado, no dejan de tener, como es lógico, un carácter muy general, y es por ello por lo que yo creo de interés concretar un poco más, delimitar más precisamente el concepto de esta arma blanca, recogiendo a continuación las características diferenciadoras de la navaja antigua española.

\section{Características diferenciadoras} de la navaja antigua española

Tipo plegable: La hoja, que gira sobre su extremo o talón, se aloja dentro de unas cachas.

Mecanismo de apertura y cierre: Posee un mecanismo que puede ser de diverso tipo y asegura la inmovilidad de la hoja cuando la navaja está abierta.

${ }^{10}$ Madrid, 1956, pág. 913.

"Madrid, 1912, pág. 564. 


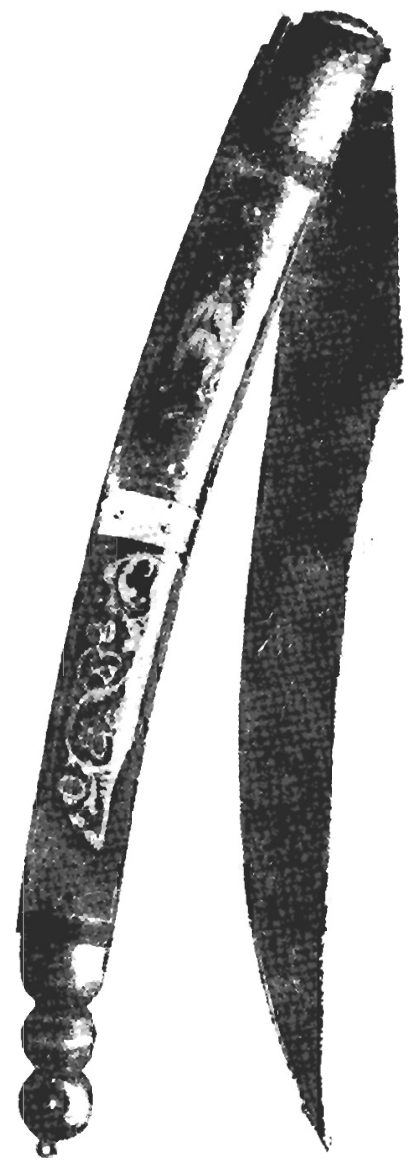

a

$b$

Figs. 5a-5b.-Navaia. Hueso, nácar y acero. $31 \mathrm{~cm}$. Quizá fabricada en Filipinas (Col. José Díaz Cezar).

$R .2161 / 2162$ 
La boja: Tiene una sola hoja con un solo corte. Su perfil suele ser curvo, aunque sea ligeramente. En el lado del filo esta forma curva es manifiesta. Con frecuencia tiene leyendas grabadas.

Las cacbas: Tienen como finalidad servir de protección a la hoja cuando está ccirada y a la persona que la porta. Su forma sigue en gran medida la del filo y, por tanto, suelen ser algo curvas. Generalmente terminan en punta y llevan un refuerzo o virola en los extremos.

\section{Etimología y primeros usuarios de la voz}

Según el Diccionario crítico etimológico de la lengua castellana, de J. Corominas ${ }^{12}$, navaja viene de «novacula», siendo Gonzalo de Berceo (primera mitad del siglo xiII) el primero que deja constancia de la voz. También figura en el Libro de buen amor (1330), del Arcipreste de Hita, y en el Conde Lucanor, de don Juan Manuel (siglo xiv). Se recoge igualmente en el Vocabulario universal en latín y romance, de Alonso Fernández de Palencia, editado en Sevilla en 1490.

Por otro lado, Julio Cejador Frauca, en su Tesoro de la lengua castellana ${ }^{13}$, señala que la voz (nabâlī de nabâlya) era de uso general en el mundo mozárabe (siglos XII y XIII concretamente), y así fue utilizada por el poeta cordobés Abencuzmán (muerto en 1159) e incluida en el Diccionario latino-arábigo y arábigo-latino, conservado en un códice escrito en España en el siglo xiır, atribuido a Ramón Martí.

Al parecer, de «novacula» se pasó a «navacula» y de ahí a «navalia» y finalmente a «navaja».

Raimundo de Miguel, en su vigésimo cuarta edición del Nuevo diccionario latino-español etimológico ${ }^{14}$, menciona la utilización de la palabra navaja en el sentido de arma blanca, en Cicerón (106-43 a. C.) y Marcial (40-103 d. C.).

Finalmente, citemos El Libro de Alexandre, del siglo xin («busco bonas navaias, el fierro bien templado»), y Scriva, en su Venesis Tribunal (1537), dice: «... con dura navaja abría el delicado pecho» ${ }^{15}$.

I: Editorial Gredos, S. A., Madrid, 1956, tomo III, págs. 504 y 505.

1: Tomo VI, Madrid, 1902.

"Madrid, 1946.

15 Leguina, op cit, pág. 664. 


\section{Otras denominaciones}

Por ser la navaja un instrumento tan sumamente utilizado por todas las clases sociales, incluso en las más recónditas regiones de la Península, de los Austrias acá ha recibido muy diversos nombres, de entre los que recogemos algunos que acreditan su enorme popularidad en nuestro país. Se le llamó abanico, alfiler, cabritera, cortaplumas, corte, chaira, charrasca, faca, herramienta, hierro, machetona, mojosa, mondadientes, navajón, perica, pincho, santolío y tea.

\section{Materiales empleados}

Entre los materiales más frecuentemente utilizados estaban la madera de las especies más diversas, el hierro, el acero, el latón, el cobre, la plata, cl oro, el carey, el asta de toro o cérvido, el hueso, el marfil y el nácar.

Los motivos por los que se utilizaban unos u otros materiales eaan principalmente la facilidad de obtenerlos, su duración de uso, la facilidad de trabajarlos, su belleza natural, el precio y su aspecto externo, como el brillo, colorido, etc.

De todos estos materiales, el más importante, el que daba más prestigio a la navaja y a su fabricante, era sin duda el acero con que estaba hecha la hoja, que cuando era de buena calidad y estaba bien forjado y templado le proporcionaba dureza, flexibilidad y seguridad. Si no hubiera sido así no se hubieran podido someter estas armas a las duras pruebas con que se enorgullecían muchos artífices españoles, que como Paco el Facas, maestro «templaor» de Cuevas, muerto allá por el año 1934 y perteneciente a una dinastía de trabajadores que seguían transmitiéndose los secretos de padres a hijos, «acostumbraba cuando vendía una navaja a probarla siempre a la vista del comprador, prueba que consistía en poner una moneda de diez céntimos, coger la faca y darle una puñalada y tener que perforarla completamente. Una vez perforada, veía el arma, la tocaba y la estudiaba con mucho cuidado. Si no se había roto ni torcido, la vendía. Como se hubiera roto, aunque le hubieran dado mil duros por ella no la hubiera vendido jamás» ${ }^{16}$.

${ }^{16}$ Cuadrado, op. cit., pág. 389. 


\section{Formas}

Al hablar de las características diferenciadoras de la navaja antigua española ya indiqué los aspectos más importantes de ésta. Pero no está de más insistir ahora en que la navaja tradicional era de una sola hoja. La navaja de doble hoja o de usos múltiples, con otras hojas más pequeñas, sierra, lima, punzón, destornillador e incluso tijeras, es una invención, muy útil por cierto, pero relativamente moderna, y que responde a finalidades distintas.

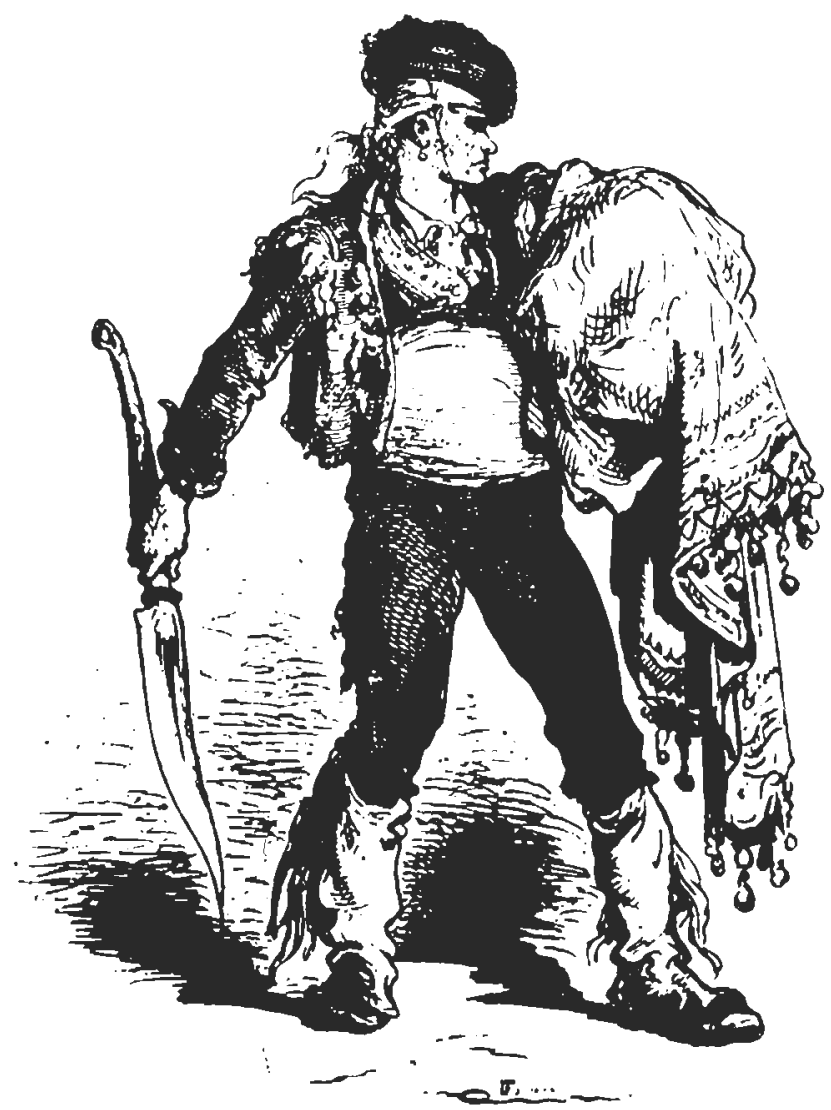

Fig. 6. - «La Navitia», de Gustavo Doré (Barón Charless DaVILLIER: L'Espagne, 1874, p. 100).

R.2048 
Una nota de manifiesto interés es su gran tamaño. Por supuesto, las había más pequeñas, pero éstas son las menos. Las dimensiones más corrientes eran -y la estoy considerando como siempre en su posición de cerrada - de 18 a $24 \mathrm{~cm}$., duplicándose su tamaño al abrirla. También son frecuentes las navajas de siglos anteriores que superan con creces estas dimensiones, llegando incluso a los 50 y $60 \mathrm{~cm}$., pero en todo caso no son ni mucho menos tan numerosas como éstas. La navaja que se fabrica en la actualidad oscila entre los 10 y los $14 \mathrm{~cm}$., es decir, que son prácticamente la mitad de largas que las antiguas.

Las formas de la hoja eran diferentes, aunque siempre más o menos curvas; pero no poseían esa gama enorme de perfiles que hoy presentan los catálogos de los navajeros más importantes de nuestro país. Así, por ejemplo, en Albacete los cuchilleros hablan de estilete, punta espada, albaceteña, sevillana, jerezana, lengua de vaca o capaora, punta cortada, tranchete, etc.

\section{Decoración}

\section{Las cachas}

No nos referimos aquí a la armadura interna de la navaja, sino a su aspecto externo.

Las cachas son de muy diversos materiales, especialmente de asta, latón, hueso y carey, y tienen formas moldeadas y adornos cincelados de muy variada índole, que no faltan en sus dos extremos, superior e inferior. Los dibujos recuerdan mucho a los temas decorativos mediterráneos e incluso hispano-árabes (aunque menos de lo que la gente cree, ¡lo árabe tiene tan buena prensa en España!) tan frecuentes en las otras armas blancas, especialmente en los puñales. Su línea externa y la decoración dan con frecuencia a las navajas un aspecto fusiforme y a menudo recuerdan a ciertas especies de peces.

Las más elaboradas tienen unos calados y orificios que dejan al descubierto lentejuelas de cobre de este color e incluso algunos pequeñísimos espejos («navaja de espejillos»).

\section{La hoja}

La hoja suele tener por ambos lados dibujos hechos al aguafuerte con motivos vegetales que se entremezclan y que ocupan la parte próxima al recazo, algunos de cuyos motivos se asemejan mucho entre sí en nava- 


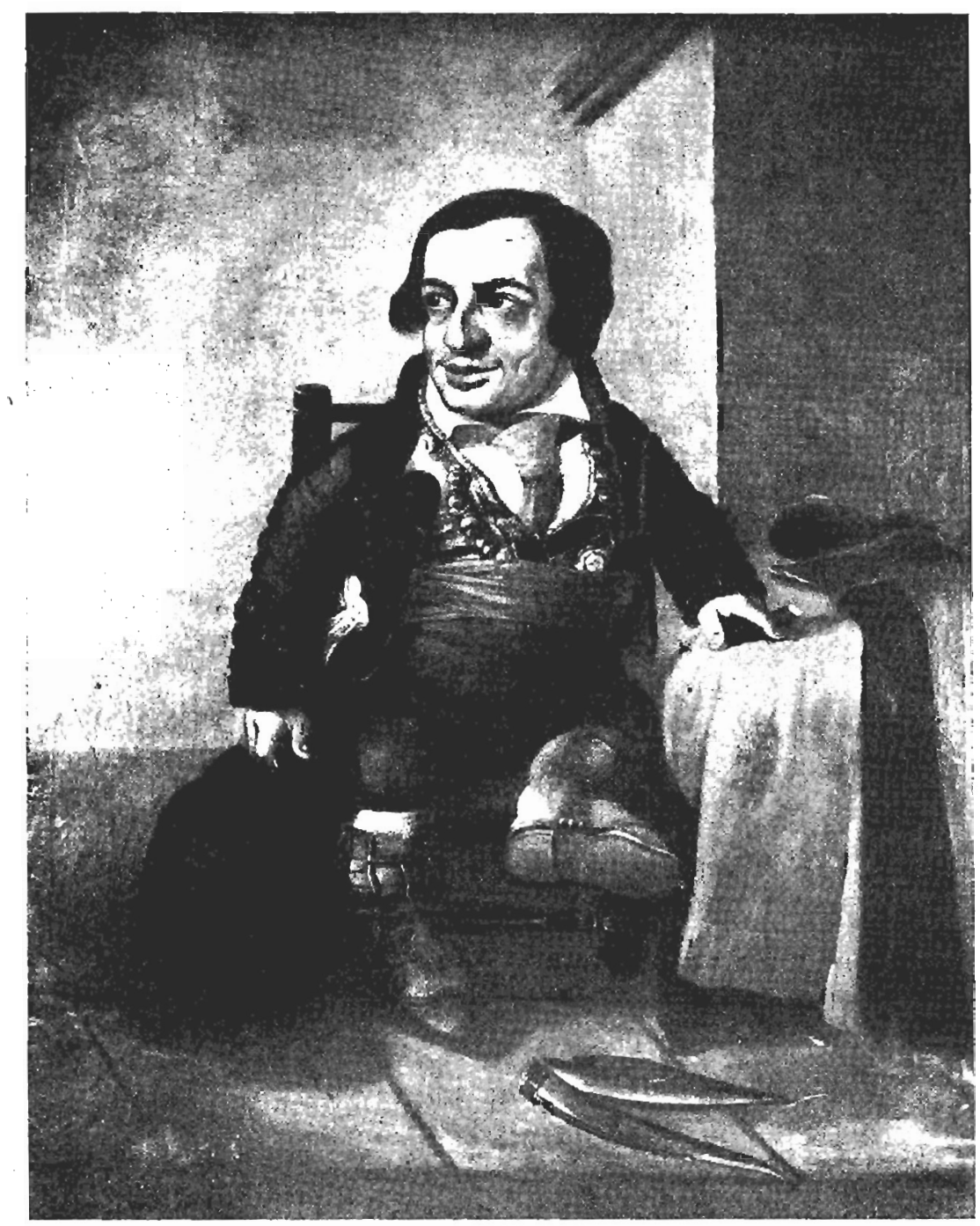

FIG. 7. «El enano de la venta» (Múuseo Taurino de Madrid, cuadro núm. 43). 
jas del mismo tipo. Frecuentemente están éstos pintados de color rojo sangre de toro.

Con frecuencia tienen incrustaciones de latón en forma de pequeños círculos y leyendas breves, variadas y pintorescas.

A menudo aparecen orificios artísticos en forma de cruz, corazón, etc., que atraviesan la hoja dándole a ésta una mayor belleza.

Entre las de tipo popular es frecuente encontrar rayas hendidas y pintadas, generalmente de rojo, que corren paralelas a la parte no afilada de la hoja.

Es muy corriente que aparezcan muescas perpendiculares en el recazo, más o menos artísticamente ejecutadas, que en contra de lo que la gente cree no tienen otra finalidad que la puramente decorativa.

\section{Leyendas grabadas}

Es curioso lo extendido de la costumbre de grabar leyendas pintorescas en la hoja de la navaja española.

El deseo o necesidad de personalizar la pertenencia de una navaja, la conexión con un determinado lugar, principios de exaltación del honor y del valor tan en boga en épocas pasadas y otras razones similares motivaron estas inscripciones en ciertas navajas antiguas españolas.

La sin duda favorable acogida popular hizo que lo puramente anecdótico se convirtiese en habitual, y muchos fabricantes escribieron estas leyendas en las hojas de sus mejores piezas. Estoy convencido de que esta nota pintoresca incrementaba su tipismo y facilitaba, en consecuencia, la venta de estos artículos de gran consumo, y de ahí su generalización.

Es lástima que por el uso a que habitualmente están destinados estos objetos que nos ocupan muchas de las inscripciones se hayan perdido totalmente y otras veces se haga imposible la lectura en su totalidad de lo grabado en su día. Ello, no obstante, recogemos a continuación las leyendas que personalmente hemos leído o - las escasísimas- que hemos recogido de publicaciones dignas de crédito:

Viva mi dueño.

Viva el bonor de mi dueño.

Viva el valor de mi dueño y señor.

Vivan mis dueños valerosos, que quien sólo a mirarlos se atreviere sentirá mis colmillos venenosos.

Viva la libertad.

Viva Figueras. 
Viva el amor.

Soy de uno solo.

Soy de mi dueño y señor.

Defensa de mi dueño.

Soy defensa de mi dueño.

Soy defensa del bonor de mi dueño.

Soy deferisa de mi dueño y señor.

Soy de mi dueño, a quien sirvo.

Soy defensora de mi dueño solo y viva.

De mi dueño sola.

Si esta vibora te pica no vayas por ungüento.

Si esta vibora te pica no acudas a la botica.

Si esta víbora le pica no vayas por ungïento a la bolica.

Al que esta sierpe, por azar, le pica, que no busque remedio en la botica.

Sirvo a una dama.

Prendida en la liga defiendo a mi señora.

No me abras sin razón ni me cierres sin honor.

El que desnuda y en acción me viere, prevenga testamento y sepultura, que mi boja siempre mala cuando biere.

El hombre propone y Dios dispone.

Soy sola para cortar.

\section{Mecanismo de apertura y cierre}

Los mecanismos de apertura y cierre son de diversa índole y varían según épocas y procedencias.

Entre los más frecuentes están los que se basan en la simple presión ejercida por una varilla de acero («cierre de varilla») ligeramente curvada y más o menos cuadrangular que discurre a lo largo y por entre las dos cachas, sirviendo de sujeción a éstas y ejerciendo la fuerza suficiente para mantener firme la hoja en cualquiera de sus dos posiciones permanentes, la abierta o la cerrada, a base de encajar en su extremo superior un saliente situado en el talón de la hoja y que actúa a modo de seguro cuando la navaja está abierta.

Una variante de este sistema es la llamada «navaja de muelles», que consta de varios pequeños escalones o muescas en el talón de la hoja y 
que produce un ruido especial al golpear el muelle o varilla en la base de cada uno de estos dientes cuando se acciona para abrirla.

Otra forma muy extendida entre las navajas populares españolas es la de esta misma varilla metálica en cuyo extremo superior hay una parte achaflanada y ligeramente saliente para poder accionarla con los dedos, provista de un orificio alargado o ventana ( «cierre de ventana») que sirve de sujeción a los dientes de la hoja. Este mecanismo de apertura y cierre no se da, que yo sepa, en la navaja antigua extranjera.

Otro sistema más moderno es el de anilla, que sujeto a la parte superior de la varilla facilita el cierre de la navaja al poder separar más eficazmente el muelle en cuestión.

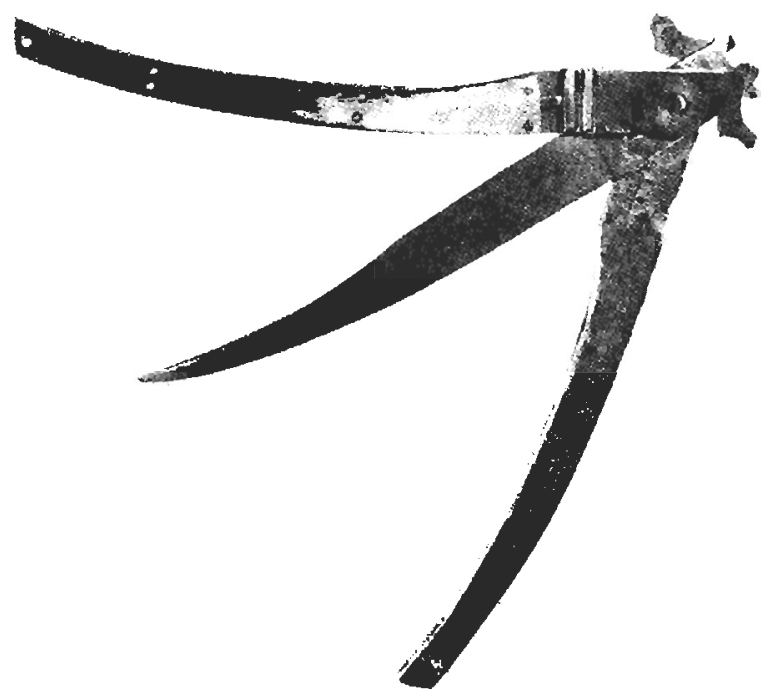

Fig. 8.- Navaja de secrelo. Véase Catálogo núm. 41.

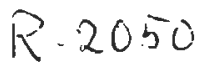

El sistema más moderno es el de una lengüeta que, fijada en la parte superior de la varilla metálica, facilita el cierre al accionarla. También aquí pueden existir una o varias muescas.

Otro sistema menos frecuente es el de asegurar la posición de apertura de la navaja a base de un anillo o virola («cierre de virola giratoria») que, situados en la parte superior, giran alrededor de las cachas —que necesariamente tendrán forma redonda- y cierran el alojamiento de las guardas asegurando su posición e impidiendo todo movimento a la hoja.

Existen otros sistemas más o menos secretos («navajas de secreto»), como son los de reloj —en que es preciso colocar las saetas en la posi- 
ción correcta prevista para poder hacer girar la hoja- o aquellas en las que sólo accionando cierto resorte, a primera vista indiferente, puede abrirse y cerrarse sin mayor dificultad.

FIG. 9.-Navaja de Toledo. Véase Catálogo núm, 31. R. 2051

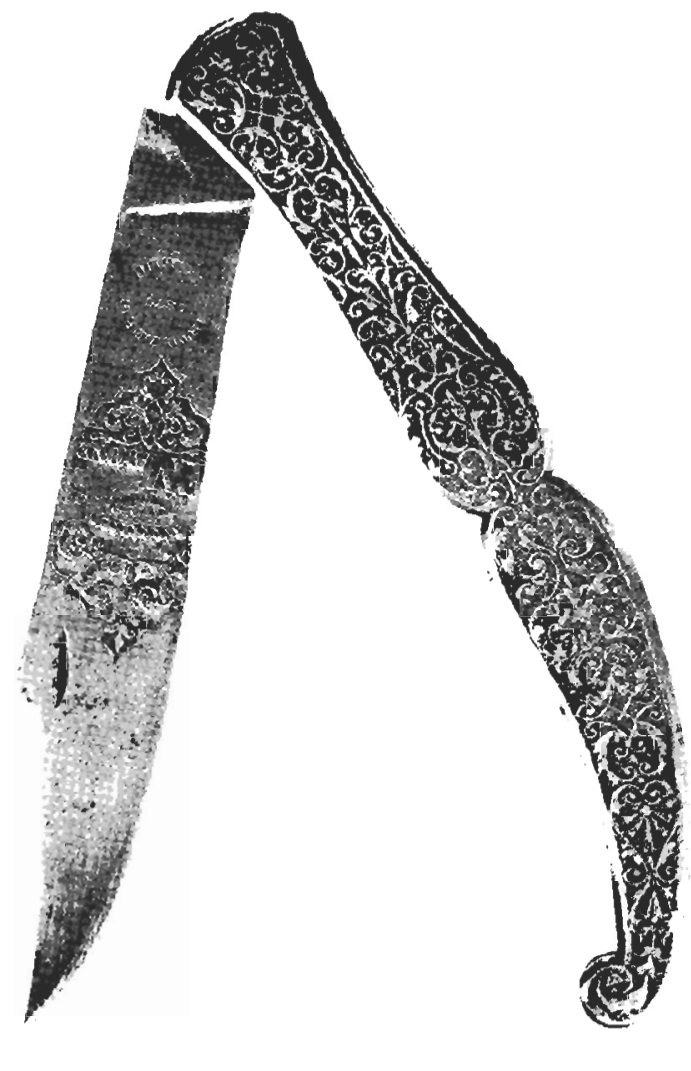

Finalmente, mencionemos otros sistemas cuya característica es precisamente la ausencia de cierre específico, lo que nos hace pensar que en su tiempo el ajuste era muy fuerte e impedía su movimiento o quizá que tenía un propósito exclusivamente decorativo. 


\section{Usos}

La gran popularidad de la navaja y el hecho de que haya sobrevivido a través de los tiempos hay que explicarlo a través del carácter polifacético y práctico de que goza, ya que tanto vale como arma defensiva que si se la considera instrumento de trabajo o herramienta casera.

La navaja sirve en el campo, en los viajes, excursiones, cacerías y monterías como cuchillo y tenedor. Con ella cortamos el pan, la carne y el pescado, pelamos y seccionamos la fruta, echamos la sal, mojamos en los caldos y guisos, con ayuda del pan reemplazamos a la cuchara y hasta con ella los enamorados escriben artísticamente sus nombres en los árboles.

En nuestros paseos por el campo hacemos uso de la navaja para limpiar una vara, cortarle los nudos a una caña o rama y hacernos con ella un bastoncillo que nos acompañe y facilite el camino.

En los pueblos de la Mancha, Andalucía y Castilla es frecuente ver cómo se hace uso de la navaja para deshollar un conejo, matar y descuartizar un cerdo, un cordero o un cabrito, capar un gorrino y hacer tantos otros imprescindibles menesteres. $Y$ dentro de este ambiente rural, se utiliza también la navaja para vendimiar.

En nuestra casa, todos, con la navaja, sacamos punta al lápiz, cortamos las cuerdas, abrimos ciertos objetos y cajas herméticamente cerradas, sacamos los corchos rebeldes y la utilizamos de abrecartas y hasta de destornillador.

En la industria se utiliza para cortar el tabaco y para encuadernar libros, para el ejercicio de la pesca y la navegación deportiva y hasta existe todo un libro en el que se explican las habilidades y mañas para hacer con ella lucidos juegos de manos ${ }^{17}$.

Aún hoy - y esto se lo he visto hacer muchas veces a mi propio padre, hombre bueno y respetuoso con los hábitos aprendidos de sus mayoreses costumbre en muchas zonas rurales bendecir el pan haciendo una señal de la cruz con la punta de la hoja sobre su parte superior antes de repartir éste a los que acompañan al cabeza de familia a la hora de comer.

Finalmente, citaré el papel tan importante que desempeñó durante nuestras guerras y guerrillas contra las tropas napoleónicas, cuando, como dice el Duque de Tovar, cada paisano podía ser un guerrillero encubierto ${ }^{18}$.

17 Arturo de Ascanio y Navaz: Navajas y dallonismo, magia de las navajas, Sociedad Española de Ilusionismo, Barcelona, 1958.

18 Op. cit., pág. 13. 


\section{Geografía de la navaja}

La navaja es algo típico y propio de la nación española. Por supuesto que en determinadas épocas pasadas se fabricaron también navajas en el extranjero, pero aun así éstas fueron producidas a imagen y semejanza de las que los artífices españoles habían creado y con las que tenían acostumbrados a sus connacionales. Es más, la mayor parte de las que se hacían fuera se vendían en nuestro país, donde la ruina de la industria cuchillera había sido total debido a una serie de causas que en otro apartado estudiamos. En la mayor parte de Europa abundó siempre, ¿cómo no?, el arma blanca corta; pero se trataba de cuchillos, puñales, machetes, cuchillos plegables, y cuando se fabricaron navajas, éstas tenían un aspecto $\mathrm{y}$ formato que el experto distingue fácilmente de las habitualmente producidas en nuestro país. Sus notas más sobresalientes y diferenciadoras son la hoja y las cachas rectas.

Así, pues, la navaja — palabra por otro lado muy difícil de pronunciar por los europeos- no sólo es algo típico de España, sino que es originaria de nuestro país. En muy diversos momentos salieron de España navajas, y cuando empezaron a producirlas en el extranjero, en su mayor parte vinieron a la Península Ibérica y se distribuyeron y vendieron por todas las provincias españolas.

Desde el siglo XIX la navaja dejó de ser algo exclusivo de nuestro país y se extendió por todo el sur de Europa y Asia, como no podía menos de ser, pues su manejabilidad, seguridad, bajo precio, facilidad para llevarla y carácter polifacético de sus usos tenía que encontrar un abundante mercado.

Hoy se encuentra en todo el mundo; pero en el siglo xvirI, además de en España, se fabricó en Inglaterra, Alemania, Portugal, Francia, Italia, Yugoslavia y Grecia, es decir, en los países bañados por el norte del mar Mediterráneo, además de los tres primeros citados.

En los países del norte de Africa, donde el arma blanca es tan importante, la navaja no se conoce.

Sí se produjo y utilizó la navaja en Hispanoamérica, y de manera especial en Méjico y Centroamérica, porque allí fueron los españoles y allí acudieron nuestros artesanos en busca de nuevos mercados y mayores facilidades para su industria.

Por lo que a España en concreto se refiere, parece ser que pese a lo generalizado y continuado del uso de la navaja, se dio ésta con mayor intensidad en ciertas zonas. Así, por ejemplo, no estaba tan arraigada ni tan incorporada a la vida cotidana de los habitantes del noroeste español como lo fue en la zona sur y levantina. Confirma esta tesis la circunstan- 
cia de que de los treinta y ocho lugares que hemos recogido en que en algún momento se fabricaron navajas, estén todos ellos situados en la mitad oriental y meridional de nuestro variado país, que concretamente son: Albacete, Alcázar de San Juan, Aspe, Baeza, Barbastro, Baza, Egui, El Bonillo, Cuenca, Cuevas, Guadix, Jaén, Játiva, Jerez de la Frontera,

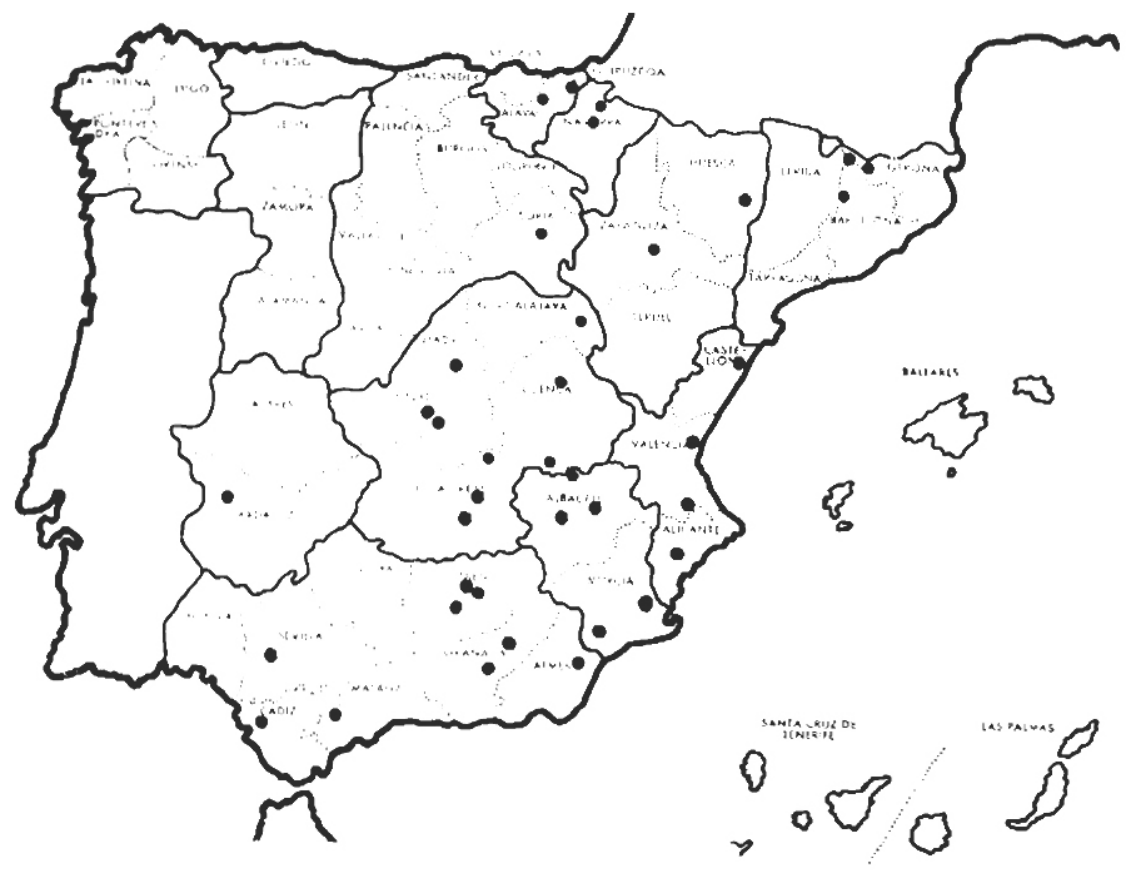

F1G. 11.-Mapa de España en el que se indican los lugares en que en algún momento se fabricaron navajas.

$R \cdot 2053$

La Solana, Lorca, Madrid, Molina de Aragón, Mondragón, Montijo, Mora, Murcia, Olot, Pamplona, Peñíscola, Ripoll, Ronda, San Clemente, Santa Cruz de Mudela, Sevilla, Solsona, Soria, Toledo, Tolosa, Ubeda, Valencia, Villagordo y Zaragoza. 


\section{Origen y evolución histórica}

\section{Edad Media y siglo xv}

A nuestro juicio, durante la Edad Media y el siglo xv no existieron las navajas como tales. Existió, qué duda cabe, una industria artesana relevante de armas blancas cortas que producía puñales, dagas, estiletes, cuchillos, moharras, tijeras, cañabetes, estoques, etc, pero no lo que hoy cualquier persona considera como navaja.

Apoyamos nuestra tesis en los siguientes argumentos:

1. Que pese a la cuidadísima atención que siempre hemos puesto en este tema por considerarlo fundamental, nunca hemos visto pieza alguna en los museos visitados y en las colecciones particulares que se pudiera identificar con absoluta certeza como de aquellas centurias.

2. Que dentro de las disposiciones legislativas referentes a armas blancas y a las normas que regulaban la actuación de los gremios de cuchilleros, nunca aparece mención alguna concreta que permita pensar se. riamente en la producción de navajas en aquella época.

3. Que pese al uso de esta voz en algunos textos literarios, no parece confirmado que ello corresponda exactamente al arma blanca que en este trabajo contemplamos (El libro de Alexandre, el Libro de cantares del Arcipreste de Hita, etc.).

4. ${ }^{\circ}$ Que la iconografía de estos siglos nada ha dejado a la posteridad que nos revele la existencia de esta arma blanca en concreto.

5." Que todas las publicaciones serias que hemos podido consultar sobre el tema confirman indirectamente la tesis sostenida aquí.

\section{Siglo XvI}

Creemos que es muy a finales de este siglo cuando aparece por primeda vez en España la navaja como tal. Su fabricación y creciente uso se acentúa año tras año, aunque nunca de forma masiva. Así lo atestigua ya, en 1537, Scriva en Venesis Tribunal al decir: «En la riquíssima medalla de finíssimo oro: ingeniosamente era entallada vna femenil ymagen: que de vn viuo mancebo que delante tenía muerto: con dura nauaja abría el delicado pecho», y sobre todo el que el profesor Rico y Sinobas ${ }^{19}$, quien poseía unas tijeras en cuyos brazos se lee la existencia en 1590 de una «navajería» en Puebla de los Angeles (Méjico), regentada por el maestro

19 Manuel Rico y Sinobas: Noticia histórica de la cuchillería y de los cuchilleros antiguos en España, Almanaque del Museo de la Industria, Madrid, 1871, pág. 34. 
Juan Ramírez, que se trasladó a aquella ciudad desde el Viejo Continente dando origen, junto con otros, a toda una floreciente industria de armas blancas según las reglas de los maestros toledanos, lo que lógicamente hace suponer la existencia de navajeros en España con anterioridad a esta fecha.

\section{Siglo xviI}

El uso y, por tanto, la fabricación y venta de la navaja cobran un decidido desarrollo durante el siglo xvi1, y de manera muy especial durante su segunda mitad. Pese a que yo sólo conozco como fechada en este siglo,

Fig. 12.- Navaja española del siglo XVIII. Véase Catálogo núm. 15.

$$
\text { R. } 2055
$$

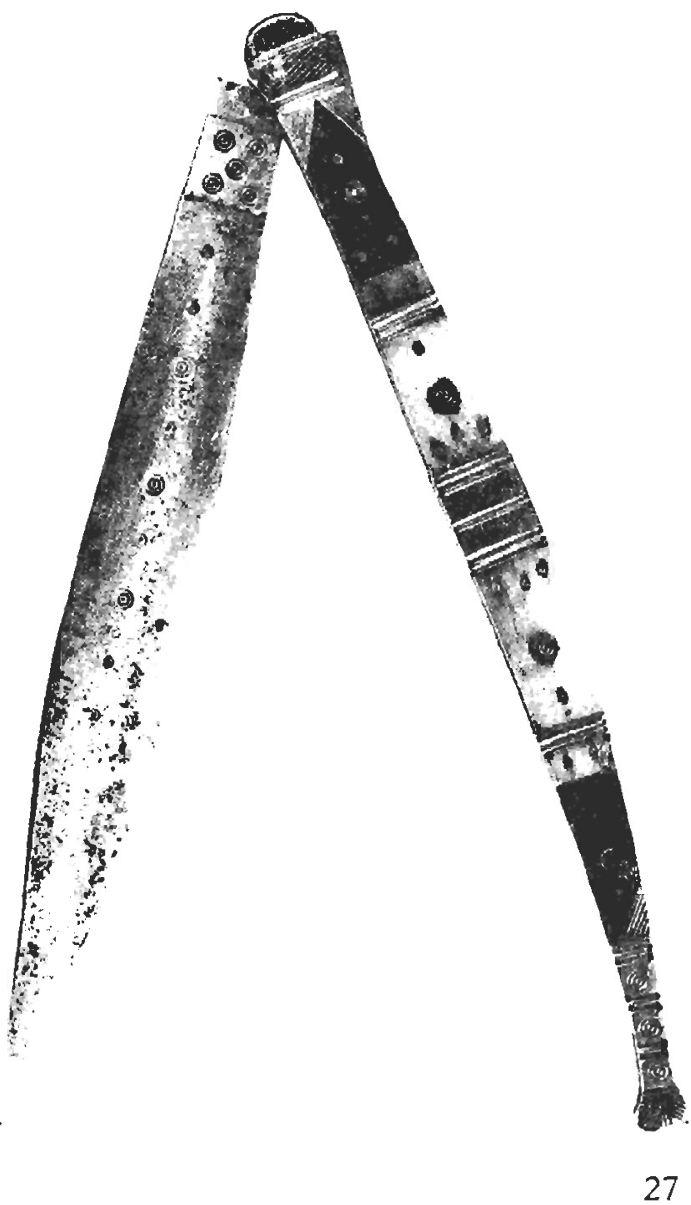




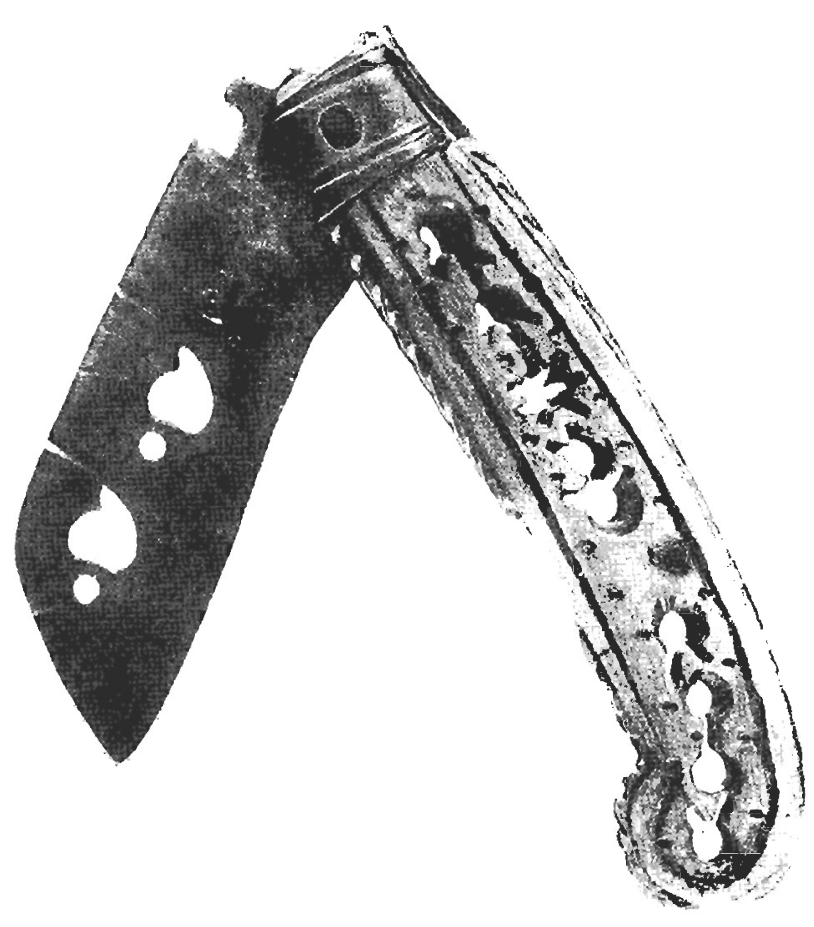

FIG. 13.-Navaja española. Véase Catálogo núm. 24.

$$
R \cdot 2054
$$

concretamente el 23 de octubre de 1699, la navaja mencionada por Rico y Sinobas ${ }^{20}$ y que describe como «preciosa navaja de secreto que tiene en las superficies de las cuchillas las leyendas latinas que siguen: "In villa de Olot principatus cathalonia fecit Paulus Llorens", y la dedicatoria al presbítero Juan de la Zarza: «Joanni Zarza, presbítero; villae de Logrosan, in sig. grat. cc.s.f.a. F. de P." Los adornos del mango de esta arma consisten en golpes de latón grabados, y representan dos esferas de reloj con sus horarios, el sol y la luna, todo con piezas movibles para esconder el secreto de abrir aquélla. Bajo de la luna se lee la fecha "Dic 23 Octub. 1699". El estado de conservación de este trabajo del maestro Lloréns; el concluido de la cuchilla, con más el gusto y perfecto concluido del puño, revelan uno de los maestros más hábiles de su tiempo», estoy seguro de que era frecuente su uso en España dado lo significativo del número de maestros cuchilleros que tanto este profesor como Juan Facundo Riaño ${ }^{21}$

20 Rrco y Sinobas, op. cit., pág. 26.

21 Spanisb Industrial Art, 1890, págs. 106-108. 
han podido recoger de diversos escritos, entre los que citan cierto legajo existente en la Real Academia de Bellas Artes de San Fernando y la Historia política de Aragón, de Calomarde, más los aportados por Gestoso ${ }^{22}$, que salvo error por mi parte ascienden exactamente a cincuenta.

El propio Tirso de Molina (1584-1648) recoge en un pasaje la siguiente frase: "Al tumbo de una navaja / Podéis tumbar un cristiano», significativa por demás de una realidad ${ }^{23}$.

\section{Siglo xviII}

En el siglo xviri continúa el pujante desarrollo de la industria navajera española, y puedo decir que en su segunda mitad y hasta 1850 tiene lugar la «época áurea» de la navaja española.

El principal argumento que se puede esgrimir es la cantidad de ejemplares que fechados en esta centuria se conservan todavía en la actualidad, y esto tiene un gran valor demostrativo habida cuenta de que se trata de un instrumento que por su finalidad y uso, lógicamente acaba destruyéndose, al igual que muchos otros elementos de trabajo, como ya expondremos en otro apartado.

En segundo lugar, durante la primera mitad de este siglo los cuchilleros son numerosísimos, si bien a finales del mismo su decadencia es manifiesta a causa de diversas, complejas y poco estudiadas motivaciones.

En tercer lugar, las frecuentes leyes de Su Majestad Católica prohibiendo el uso de la navaja y ordenando su aprehensión, destrucción, saca del reino, con el consiguiente castigo de los culpables, demuestra de forma clara lo extendida que su utilización estaba en nuestro país. $Y$ no olvidemos, por otro lado, lo significativo que resulta el hecho de que si hasta entonces las normas legales utilizaban la expresión «y otras armas cortas blancas», es a partir de 1732 cuando ya se generaliza de forma definitiva el uso de la palabra navaja y cuando se regulan por el legislador su fabricación, venta y uso.

Leguina ${ }^{24}$ confirma lo expuesto hasta aquí con su cita de El memorial lilcrario, de mayo de 1786, en que textualmente se dice: «No ha veinte años que el más infeliz artesano usaba de su espada larga para su resguardo y no sería impropio sacar al teatro un chispero con la espada

${ }^{22}$ M. José Gestoso: Diccionario de arlífices sevillanos desde el siglo XIII basta el siglo XVIII inclusive.

${ }^{23}$ Leguins, op. cit., pág. 664.

${ }^{24}$ Leguina, op. cit., pág. 664. 


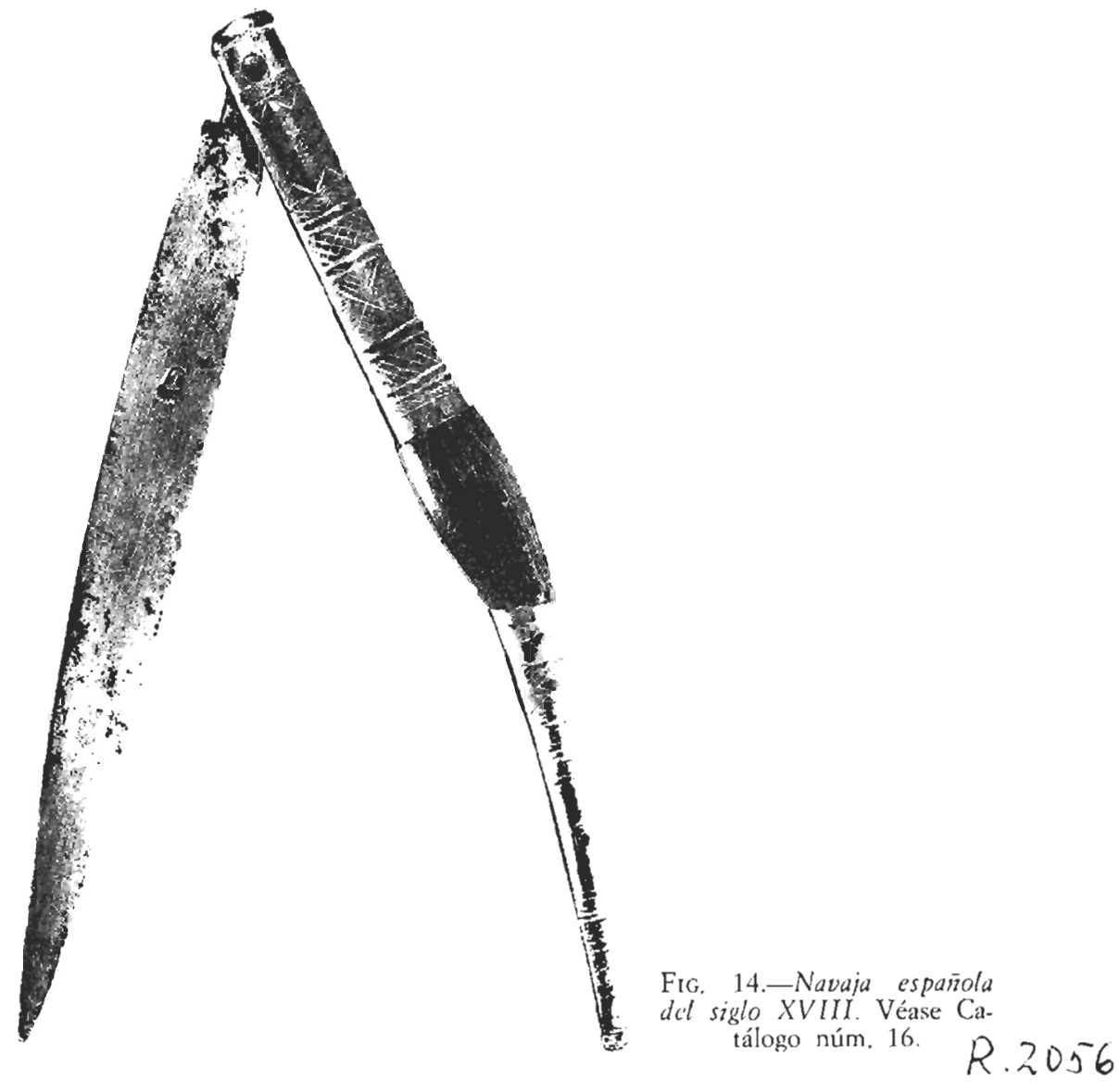

tan propia de la nación española y no negada a clase alguna. Pero se olvidó la noble esgrima y el uso mayor del tabaco de hoja, ha hecho tan necesarias a estas gentes las navajas como el pan...»

Sin embargo, en los últimos años de este siglo se producen unos hechos que tienen extraordinaria importancia para la historia de la navaja en España, que son: el agotamiento momentáneo de los aceros de Mondragón, las continuas condenas de los tribunales españoles a todo ciudadano que portase la navaja y la ventajosa competencia de la cuchillería extranjera, a consecuencia de lo cual nuestra floreciente industria decae 
Fig. 15.-Navaja española del siglo XVIII. Véase Carálogo núm. 81.

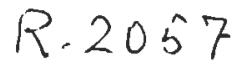

de manera vertiginosa, cerrándose los talleres y perdiéndose esta maestría que había sido orgullo de propios y envidia de extraños.

Como confirmación de lo expucsto, recogemos las palabras de Ignacio de Asso en su Historia de la economía política de Aragón, publicada en Zaragoza en 1789, que al comentar las Ordenanzas de los Cuchilleros de esta ciudad de 1591 dice: «De estas artes no ha quedado la más leve memoria, llegando a tal término su rudeza que no sólo ignoran los artífices del día el significado de las voces con que sus Ordenanzas expresan 
la obra de examen, sino que no saben hacer un mal cuchillo con filo de acero... Esta clase de industria se fue olvidando en Zaragoza después de

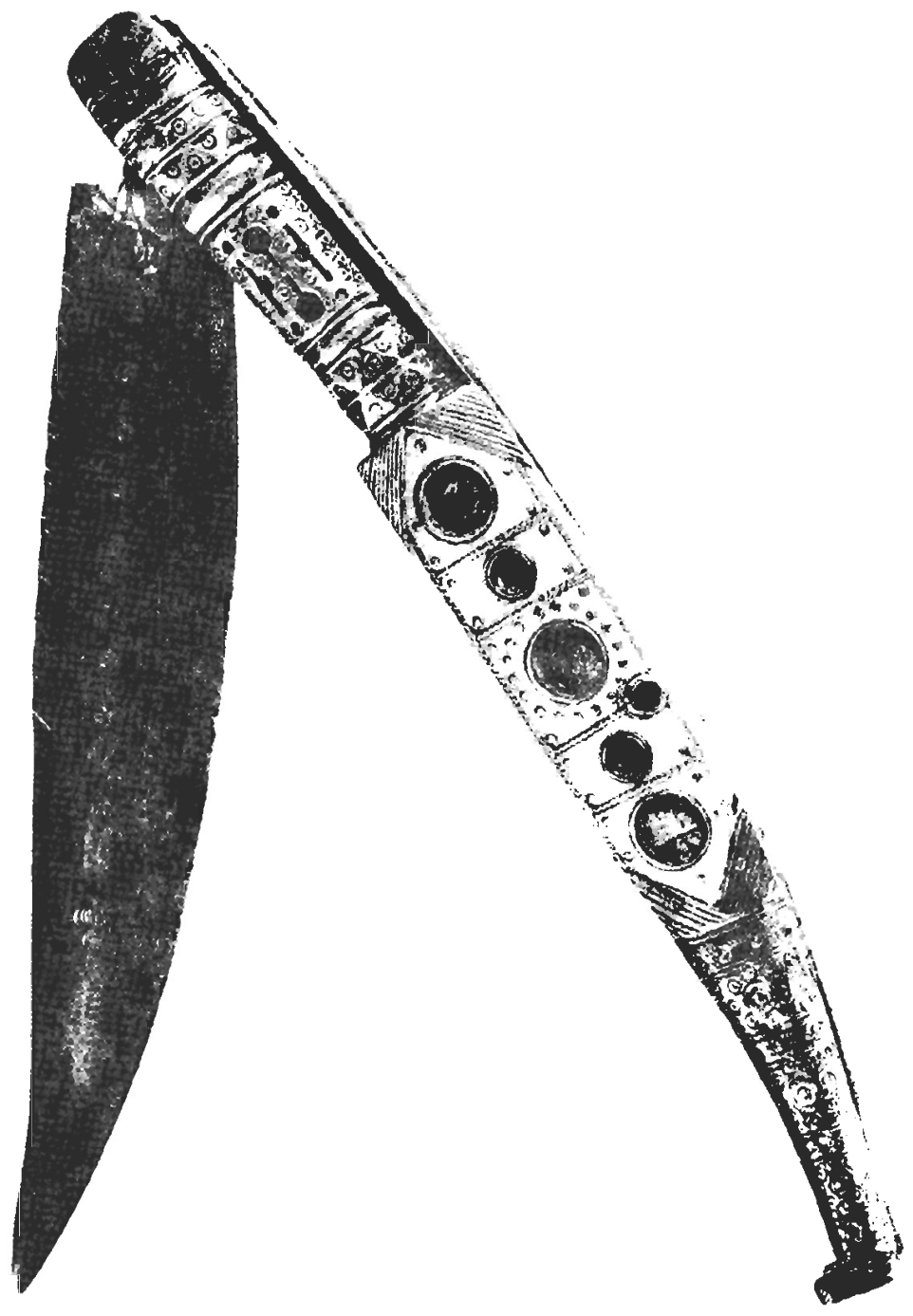

FIG. 16.- Navaja española del siglo XVIII. Véase Catálogo núm. 17. 
Fig. 17.-Navaja española del siglo XVIII. Véase Catálogo núm. 22.

la expulsión de los moriscos, quienes sobresalían en la fabricación de es-

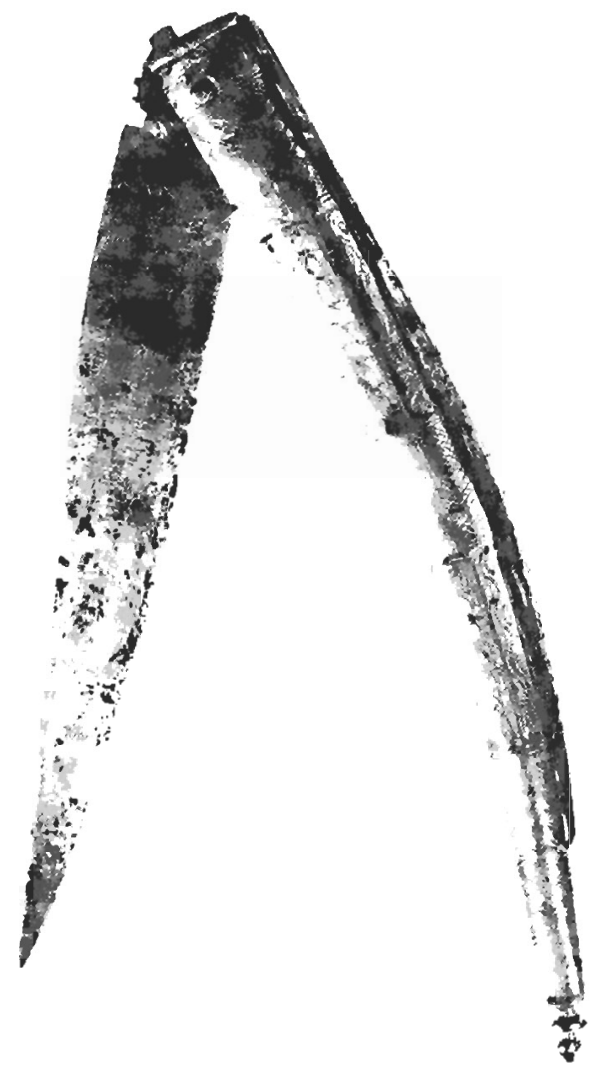
copetas, espadas, puñales...»

Pero al mismo tiempo que se produce esta decidida desaparición de la industria navajera española, el uso de la ravaja no decae en absoluto, ya que tiene lugar una invasión de nuestro país por las navajas de fabricación inglesa, alemana y sobre todo francesa, que acabaron por arruinar los pocos centros fabriles que estaban resistiendo el movimiento general de los tiempos. Rico y Sinobas ${ }^{25}$ cita el hecho de que con acero fundido y patronería de nuestro país se labraron piezas en el extranjero con el fin de contribuir más activamente al comercio de importación, con lo que se acabó por arrojar a los pocos industriales que quedaban hacia otras pro-

${ }^{25}$ Rico y Sinobas, op. cit., pág. 7. 
fesiones en las que el porvenir económico resultaba más esperanzador. Pagé ${ }^{26}$, al hablar de los vendedores ambulantes de cuchillos en España, explica cómo muchas de estas piezas habían sido fabricadas en Thiers a base de modelos españoles.

Leguina termina su cita de El memorial literario recogiendo la siguiente frase referente a la avalancha de navajas extranjeras: «... de que resulta una imponderable venta de estos instrumentos, con cuyo comercio se llevan los extranjeros mucha plata en cambio del hierro que nos dejan y antes habian sacado de nuestras ferreterías» ${ }^{27}$.

Otro hecho significativo es que en 1760 , cuando el gran rey que fue Carlos III decide crear la Real Fábrica de Armas de Toledo, como demostración de todo cuanto venía ocurriendo en nuestro país, no halló el Estado en aquel entonces otra persona capaz de dirigir la nueva institución que un tal Luis Calixto, cuchillero famoso y forjador de espadas de Valencia, cuya edad se acercaba a los ochenta años ${ }^{28}$.

\section{Siglo xix}

El siglo XIX comienza con nuevos derroteros para la vida nacional, pero la situación navajística española sigue igual. Las navajas extranjeras y especialmente las francesas no cesan de invadir los más remotos lugares del territorio patrio. El tantas veces citado por nosotros Rico y Sinobas dice textualmente: "Todo tuvo que ceder en el ramo de cuchillería, en España, desde principios de este siglo, ante el torrente invasor de la industria y comercio extranjero, inmenso por el número de sus herramientas labradas, invencible por cierta belleza, ligereza, forma y aspecto exterior, y sobre todo por la economía en los valores y precio de la cuchillería, tijerería y navajería moderna en todas sus variedades» ${ }^{20}$.

En este siglo las navajas, nacionales o extranjeras, eran un instrumento importante para el ciudadano medio español, y ello se hizo patente en las guerrillas y luchas callejeras con las que el pueblo se manifestó cruenta y valientemente contra el enemigo francés.

Alejandro Luis Laborde ${ }^{30}$ cuenta, al hablar de Zaragoza, cómo Lefèvre ocupaba ya muchas de sus calles, y todavía medroso pedía «paz y capitulación», y «guerra y cuchillo» contestaban los impávidos zaragozanos al frente de su amado general Palafox...

${ }^{2 *}$ Camilte Pagé: La coutellerie depuis l'origine jusqu'à nos jours, Châtellerault, 1904, tomo VI, pág. 1290.

${ }^{27}$ Leguina, op. cit., pág. 664.

${ }^{28}$ Rico y Sinobas, op. cit., pág. 15.

${ }^{29}$ Rico y Sinobas, op. cit., págs. 7 y 8.

30 LABORDE, op. cit., pág. 267. 


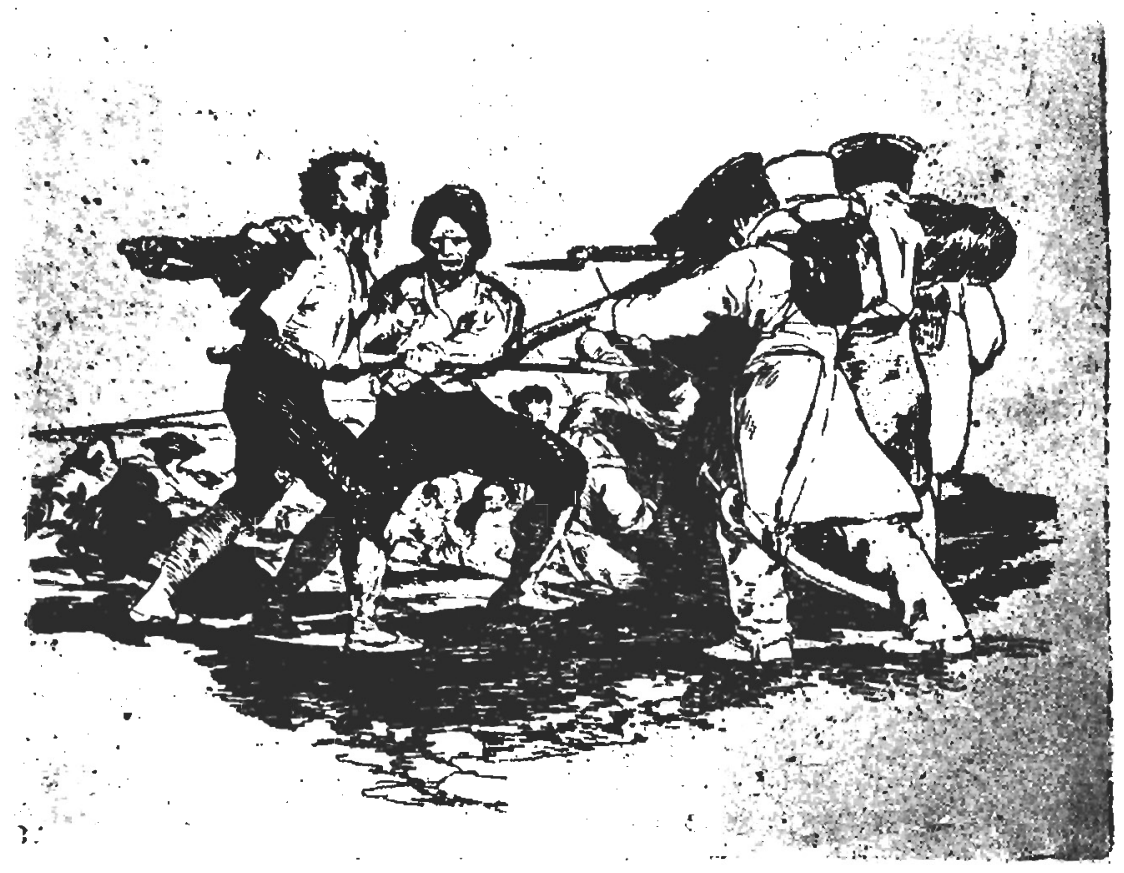

Fig, 18.- "Con razón o sin ella», de Francisco de Goya (Loys Delteıl Le Peinlre Graveur Illusiré, vol. II, París, 1922, p. 121). R. 2060

Las pinturas del genio de Fuendetodos y numerosas publicaciones de los que escribieron la historia de estos primeros años de siglo confirman estos hechos. A los dirigentes de las tropas napoleónicas no se les escapó - lo sufrieron en sus propias filas- la importancia ni tampoco los estragos que estas armas blancas cortas tenían en manos de los españoles, y es por ello por lo que se dictaron los oportunos bandos para la entrega de dichas armas a las autoridades entonces dominantes.

A mayor abundamiento, puedo también aludir a otro hecho muy significativo cual es el de que precisamente la única navaja que todavía se conserva en el Museo Municipal de Madrid ${ }^{31}$ sea una navaja francesa, de la Casa Riberon, muy semejante a la número 66 de nuestra colección, aunque algo más larga, pero en peor estado de conservación.

31 Sala del Dos de Mayo. 
Otro hecho indicativo de la popularidad de la navaja en España durante el siglo Xix es la publicación en Madrid, en 1856, por Francisco Cutanda ${ }^{32}$ de una sátira titulada La navaja, en la que en treinta y una páginas recoge en tercetos todo lo que de esta arma civil e instrumento de trabajo se puede decir.

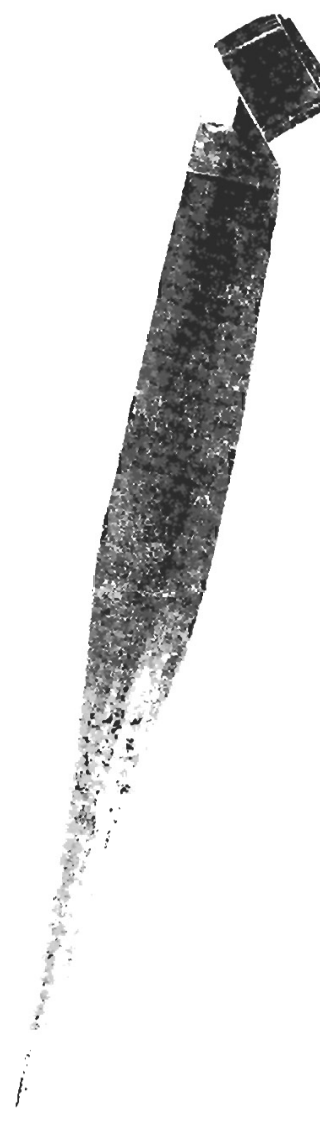

Fig. 19.-Navaja espa-
ñola del siglo XIX. Véase Catálogo núm. 28.

Finalmente citemos, para demostrar lo generalizado que se hallaba el uso de la navaja en España, los escritos de los románticos extranjeros que

${ }^{32}$ Francisco Cutanda, op. cit. 
viajaron por nuestro país entre los años 1820 a 1875 y que casi ninguno de ellos dejó de mencionar la típica navaja española, grande o pequeña, elaborada y rica o sencilla y popular, recia y masculina o liviana y feme-

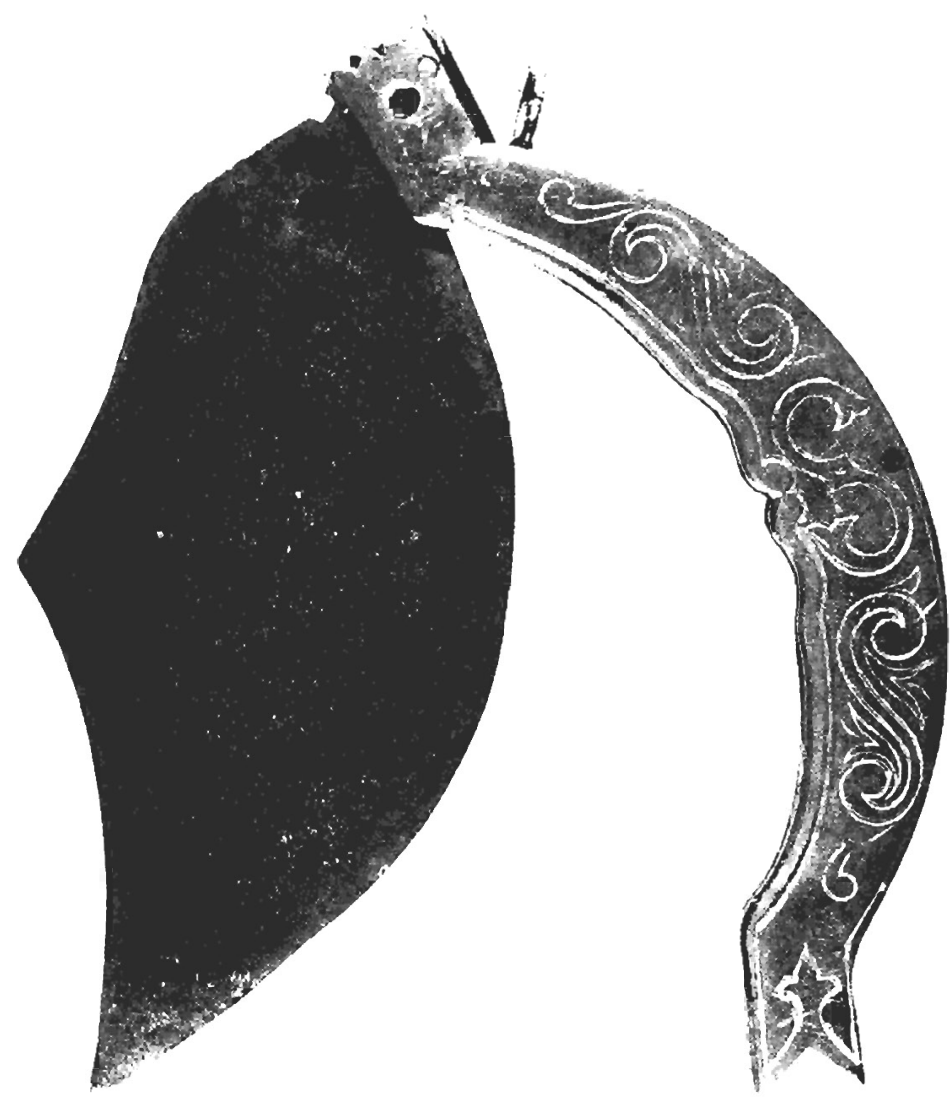

Fic. 20.-Navaja chilena. Véase Catálogo num. 77. R. 2062

nina. De tales entusiastas y arriesgados viajeros quizá los que más constancia dejaron de este hecho fueron Teófilo Gautier y el Barón Charles Davillier, acertando este último al hacer acompañar sus palabras con 


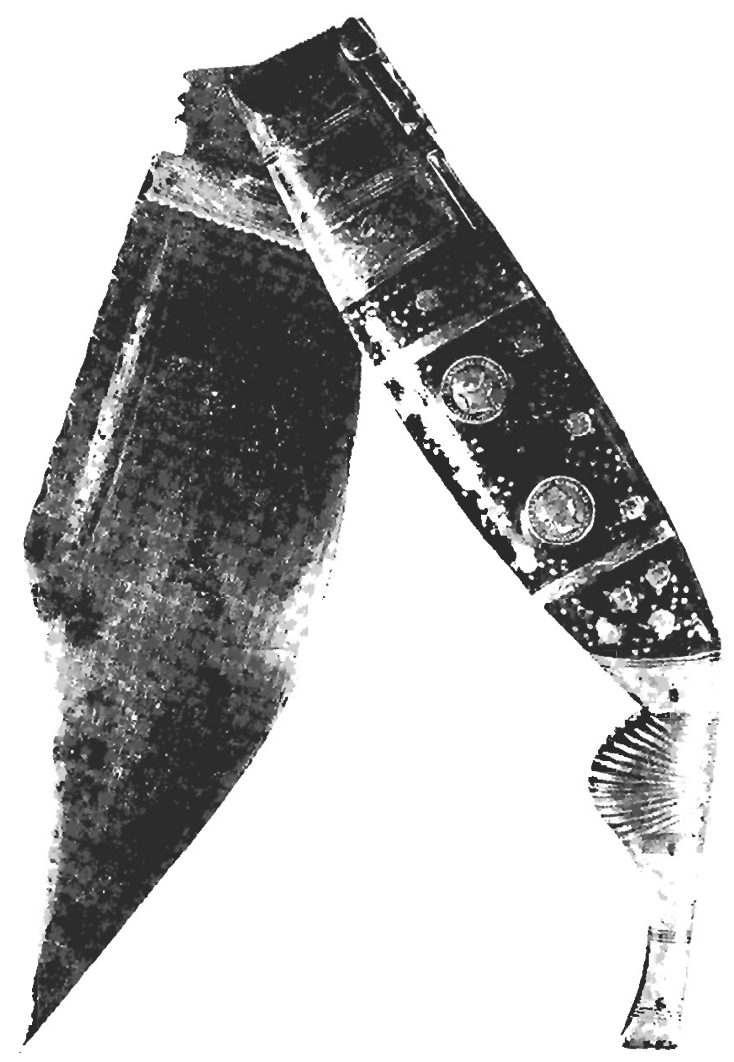

FIG. 21,-Navaja española del siglo XIX. Véase Catálogo núm. 36.

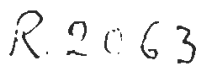

bellísimas, inconfundibles y muy elocuentes imágenes del que fue gran dibujante Gustavo Doré.

\section{Sociología de la navaja}

Creo sinceramente que la navaja fue usada por todas las clases sociales españolas, antes o después, en el siglo xvi o en el xix , mucho o poco, con fines domésticos o de seguridad personal, de fabricación nacional o extranjera, pero las utilizaron todos, ya fueran simples trabajadores agrícolas, obreros, ciudadanos, propietarios, burgueses, hidalgos o pertenecientes a la alta nobleza. 
Por supuesto que las clases económicamente más débiles eran las destinatarias netas de esta arma blanca, porque ella les era imprescindible no sólo para su propia defensa al no poder llevar espada, sino porque en la vida doméstica eran infinitas sus aplicaciones. Y no digamos nada de los habitantes de los pueblos de España - que daban la gran mayoría de la población nacionalabsolutamente imprescindible.

Lo que sucedió es que al no ser esta arma de uso típico, habitual y continuado de la alta burguesía y aristocracia - aunque basta echar una simple ojeada a alguno de los ejemplares que han llegado hasta nosotros

FIG, 22.-Navaja. Abierta mide $97 \mathrm{~cm}$. Véase

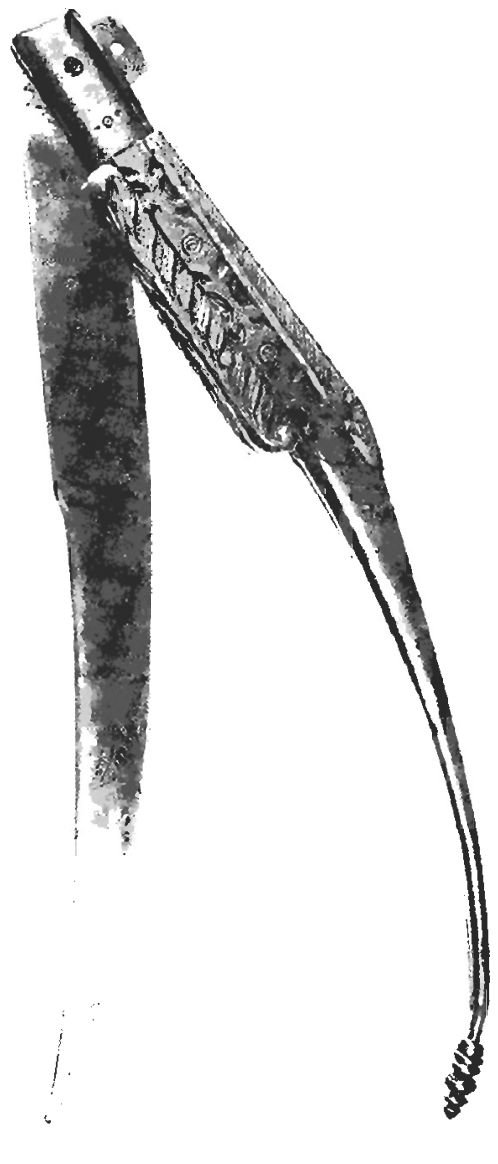

R.2064 
para darse cuenta de que sólo podían ser propietarios de las mismas gentes pertenecientes a los estamentos superiores-, y al ser generalmente éstos los únicos capaces de dejar constancia escrita de los hechos - la historia siempre la escribieron los que en cada momento mandaban y vencieron-, apenas nada escrito ha llegado hasta nosotros que desde un

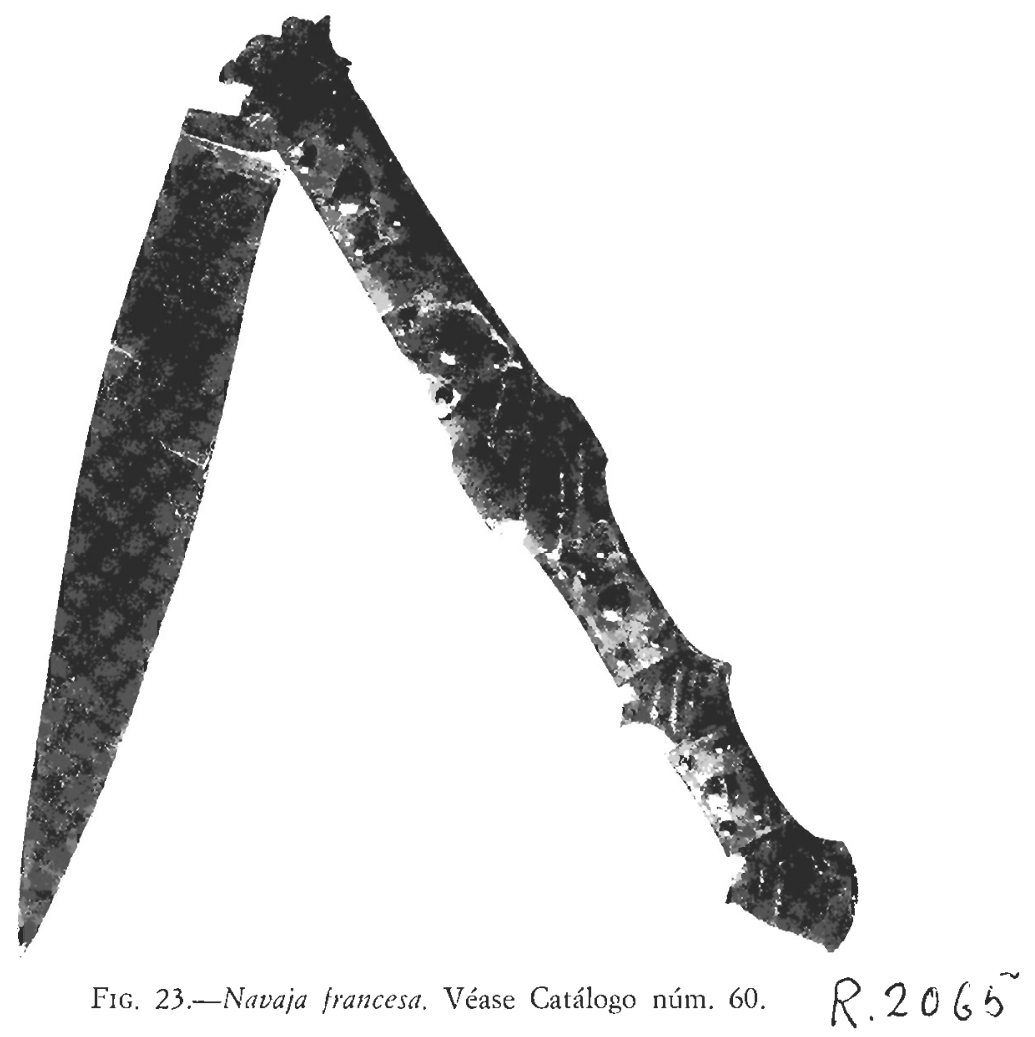

punto de vista bibliográfico permita llenar las dilatadas y frecuentes lagunas que sobre la navaja española surgen por todas partes. Muy al contrario de lo que ocurre con las armas blancas largas y otras cortas, sobre las que, en proporción, abundan los textos y escritos que han ido forjando su propia historia y defensa. 


\section{Su carácter civil}

Pese a que la navaja ha sido siempre un arma, un arma blanca, nunca ha tenido la consideración de arma militar, nunca fue reglamentaria en los ejércitos nacionales de ningún país y ni siquiera en la época actual tiene la consideración de tal. Tropas especiales como las de comandos, fuerzas expedicionarias, etc., fueron, por supuesto, equipadas con armas blancas, pero se trató siempte de pequeñas dagas, puñales, plegables o no, machetes u otras similares. Es éste un hecho que no deja de tener su interés y por ello quieto dejat constancia de él aquí.

Dentro de los tiempos modernos, que no son objeto de tratamiento en esta introducción a nuestro Catálogo, señalaré cómo la navaja que la Fábrica de Armas de Toledo produjo en 1958 para las tropas paracaidistas - siguiendo quizá el antecedente suizo- es la excepción. Y aun así es una excepción a medias, pues se trata de una pequeña navaja de usos múltiples que no tiene una finalidad ofensiva o defensiva - no tiene hoja larga y puntiaguda-, sino que más bien ha sido concebida — posee dos sierras, abrelatas, destornillador, punzón y una hoja pequeñita- para usos menores, muy distintos de los habituales en una acción bélica. Prueba de ello es que sus existencias se agotaron pronto por haber tenido una gran aceptación entre el público civil.

\section{Legislación}

La fabricación, venta y tenencia de armas blancas cortas ha sido objeto de regulación jurídica por el poder público desde tiempos muy remotos, existiendo además una normativa muy interesante que regulaba la vida de los gremios artesanos, tan importantes en la alta y baja Edad Media y durante la época moderna hasta su extinción en el siglo xviri.

Como un antecedente jurídico más entre otras muchas disposiciones más precisas que iban a aparecer después citaré, aunque sólo sea por lo alejadas que están de nosotros, las leyes XXXVIII, XXXIX y XL del Fuero de Salamanca, que en tiempos de Alfonso VII el Emperador (1126 a 1157) regulaban algunos aspectos de esta materia:

Ley XXXVIII: De sacar armas à buelta, ò las portar.- -Todo ome que sacar armas à buelta si ovier otorgamiento de tres omes ò de una iusticia peche cinco morabetinos, é se non iure si tercero. 
Ley XXXIX: De portar por la villa armas.-Todo ome que armas portar, lanza, espada ò porra ò alfange ò bullon ò cochiello con pico, ò otra arma en Salamanca peche dos maravedis.

Ley XL: Del ferrero que fecier cocbiello con pico.-Todo ferrero de Salamanca ò de su término que fecier cochiello con pico si non de palmo entre mango é la cochiella è si otro fecier è eu el mercado gello fallaren vendiendo tomelo quien quisier é peche el coto.

Los cuchilleros del Medievo, conocedores de los secretos de la forja, calzado, moldeado, temple, recocido, acicalado, montura, nielado, incrustado, grabado y tantas otras operaciones fabriles, asociados entre sí bajo la advocación de su propio santo patrón, regularon su propia vida profe-

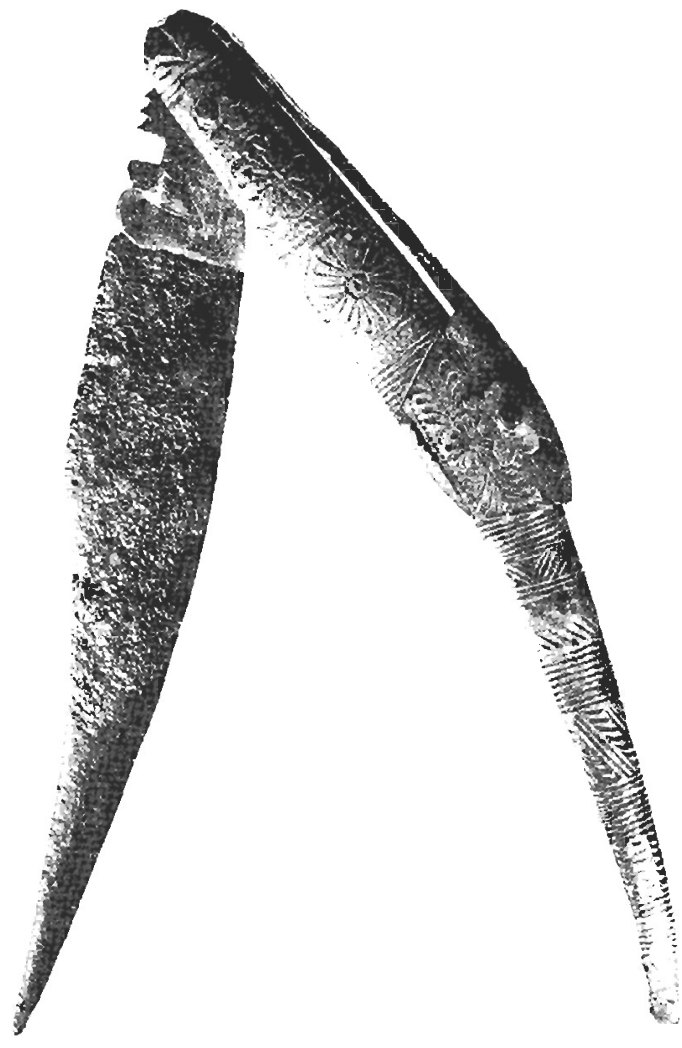

Fig. 24.--Navaja española. Véase Catálogo núm. 38.<smiles></smiles> 
FIG. 25.-Navaja de Toledo. Véase Catálogo núm. 29.

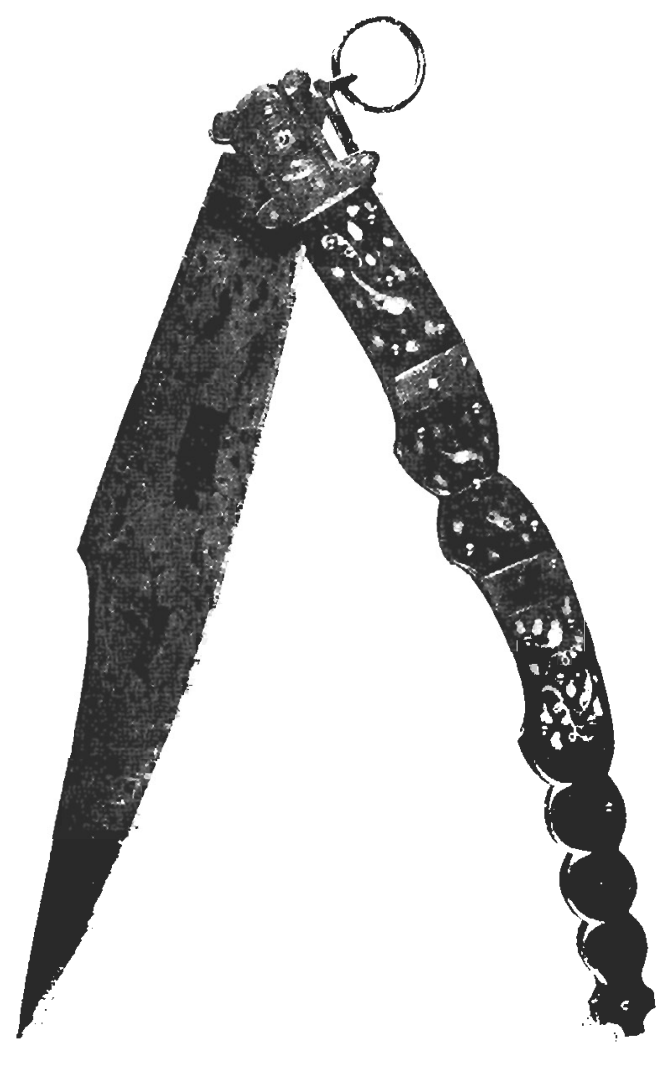

sional a base de una serie de disposiciones vinculantes que permitieron no sólo hacer de su actividad una auténtica profesión perfectamente diferenciada y estimada, sino que además de regular los aspectos económicos e industriales de la misma lograron la defensa de sus propios intereses, la mutua ayuda entre los agremiados, fijaron minuciosamente las pruebas que necesariamente habían de sufrir los aspirantes al grado inmediato superior, el registro de las marcas usadas por los fabricantes, las pruebas a que habían de someterse los nuevos modelos e innovaciones, etc., estableciendo con ello toda una normativa reguladora de las relaciones laborales.

Dentro de esta línea de normas recordamos la existencia en Aragón, en tiempos de Fernando I de Antequera (1412-1416), de la Cofradía Gremial de Cuchilleros de Zaragoza, así como la aprobación en 1420 
por Alfonso V de Aragón de las Ordenanzas de la Cofradía de San Eloy, que, escritas en catalán, todavía hoy nos deleitan con lo curioso de las disposiciones gremiales de los herreros, plateros, mariscales, espaderos, cuchilleros, fabricantes de corazas y similares en Gerona. Del mismo año son las Ordenanzas del Gremio de Cuchilleros y Vaineros de Valencia que se conservan en el Archivo Municipal de esa ciudad.

Con el correr de los años, los oficios se van desmembrando y especializando, y así lo estableció en 1512 el Concejo Municipal de Barcelona, pero dejemos que sea el mismo Campmany y de Monpalau ${ }^{33}$ quien nos lo cuente:

«De tiempo inmemorial, los Cuchilleros de Barcelona, conocidos con el nombre de Dagueros, estaban agregados como oficio de fabricantes en hierro á los cerrajeros del bárrio del Regomí. Pero á 12 de mayo de 1512 el Concejo Municipal dividió estos dos oficios á instancia de los mismos cuchilleros, atendida la notable diferencia que hay entre las dos profesiones, y quanto conviene para la perfección de las artes el subdividir alguna vez los ramos de la industria; y les dió facultad para formar su cofradía baxo la invocación de San Eloy en la Iglesia Parroquial de San Justo y Pastor de aquella Capital.

»Aprobaronseles cierto cuerpo de estatutos con los que se han gobernado hasta hoy; y se reducen á lo siguiente. Que se elijan todos los años tres Prohombres para el régimen del gremio: que estos tengan facultad por sí de juntar los vocales siempre que lo juzguen conveniente; que no puedan resolver de su propia autoridad caso alguno árduo ó extraordinario, y sí solo los comunes, según la práctica del gremio, y el tenor de sus ordenanzas; que los que hayan sido una vez Prohombres ú oficiales del gremio, no pueden volver á obtener cargo alguno sin haber mediado dos años; que cada individuo pague anualmente quatro sueldos y quatro dineros que se han de exigir por semanas para los gastos de la fiesta del Santo tutelar; que ningún maestro pueda prestar su nombre á otro só pena de veinte y cinco ducados; que para la buena harmonía de los gremiales, y perfección del oficio, en la casa de las juntas se guarde un libro en que estén estampadas las marcas con que cada individuo señala las piezas de su fábrica; que afin de evitar la proporción con que los demás fabricantes de fuera de Barcelona podían introducir fraudulentamente en ella artefactos con marcas contrahechas, se rompan aquellos que se encuentren con semejantes engaños; que para que el público y el extrangero queden bien servidos en el surtimiento de piezas de fábrica barcelonesa,

33 Antonio Campmany y de Monpalau: Memorias bistóricas sobre la marima, comercio y artes de la antigua ciudad de Barcelona, Madrid, 1779, tomo I, parte tercera, capítulo IV, pág. 66 . 
debían los maestros traher toda la obra concluída á la casa del gremio para ser allí examinada antes de poderla vender, con la ley de que no hallándose de buena calidad se rompa á presencia de los Prohombres; que los aspirantes á la maestría debían haber hecho quatro años de aprenclizage, y dos de oficialía en casa de maestro aprobado con obrador propio y corriente, sujetándose á pagar por la recepción veinte y quatro ducados.»

El 14 de febrero de 1527 Carlos I de España aprueba las «Ordenanzas de la muy noble y muy leal ciudad de Sevilla y su tierra», entre las que se contienen con absoluta independencia entre sí las Ordenanzas de los espaderos y las de los cuchilleros ${ }^{34}$.

Ignacio de Asso, en su Historia de la economía política de Aragón ${ }^{35}$, con ocasión de comentar las Ordenanzas de los cuchilleros, agujeros, anzoleros y espaderos de Zaragoza de 1591, se queja, lamentándolo, del tremendo olvido en que han quedado (finales del siglo xviII) todos los sabcres del arte de la cuchillería, sin que exista artífice alguno capaz de continuar tan sobresalientes habilidades.

Cuando hablamos de armas, nuestra hasta cierto punto justificada deformación mental nos hace pensar inmediatamente en leyes y reglamentos que prohíben taxativamente la tenencia de aquéllas o someten a un complicado y riguroso control burocrático el uso de las mismas. Pero ello no siempre ha sido así. Nuestros sabios y católicos reyes Fernando e Isabel dictaron en Tarazona, en 1495, una pragmática que trataba de poner remedio a la falta de armas que padecía el reino. Los primeros párrafos de la misma dicen así:

«Por quanto nos fue hecha relacion que en estos nuestros Reinos mucha gente, assi Cavalleros Hijosdalgo, Ciudadanos, i Labradores estaban desarmados, porque mediante la paz, que avia en nuestros Reinos, los unos deshicieron las armas, i los otros las vendieron, i otros las perdieron; por manera que, quando para alguna cosa, que cumple à nuestro servicio, i à la execucion de nuestra justicia, ó para persecucion de algunos malhechores, conviene que salga alguna gente de alguna Ciudad, Villa, ó Lugar, aquella vá por la mayor parte desarmada, i con mucho peligro, i. deshonra suya, i que si aquello se continuasse, i fuese adelante, como fasta aqui se ha hecho, se nos podria recrescer mucho deservicio, i à nuestros Reinos daño, porque podrian recrescerse cosas, porque conviniese que todas las gentes estuviesen aparejadas de armas, para ofender, i facer guerra á quien procurasse facer daño á estos nuestros Reinos, i fuenos pedido, i suplicado por los Procuradores de los Grandes, i Perlados, i Cavalleros, y de las Ciudades, i Villas de nuestros Reinos, en la Villa de

"Biblioteca del Ministerio de Trabajo, copia, págs. 527 y 555.

"35 Zaragoza, 1798, págs. 217 y 285. 
Santa Maria del Campo, por el mes de Junio deste presente año de mil i quatrocientos i noventa i cinco, dó se juntaron por nuestro mandado, que luego mandassemos proveer cerca dello, como cosa, que tanto convenía á nuestro servicio, i al bien público de nuestros Reinos: lo qual todo por Nos visto, i platicado, i acatando que esto cumple á nuestro servicio, i á la honra, i ornato, i pacificacion, i seguridad de los dichos nuestros Rcinos, i de todos los estados dellos, tovimoslo por bien, i mandamos facer, $\mathrm{i}$ hicimos sobre la dicha razon los Capitulos siguientes; los quales mandamos que se guarden agora, $\mathrm{i}$ de aqui adelante en la forma siguiente.

„Cap. I. Primeramente que todos nuestros súbditos i naturales, de qualquier lei, i estado, $\mathrm{i}$ condicion que sean, agora, $\mathrm{i}$ de aqui adelante tenga cada uno dellos en su casa, i poder armas ofensivas, i defensivas convenibles, segun el estado, i manera, i facultad de cada uno, segun se declara adelante.

"II. Que todos los que viven, i moran en las Ciudades, i Villas francas, $\mathrm{i}$ esentas, los mas principales, $\mathrm{i}$ mas ricos de ellos tengan unas corazas de acero, i falda de malla, ó delaunas, i armadura de cabeza, que sea capacete, con su babera, ó celada, con su barbote, i masgocetes, ó musiquies, con una lanza larga, de veinte i quatro palmos, i espada, i puñal, i casquete.»

Estos mismos reyes ya habían dispuesto dos años antes que se cortase la mano al herrero o armero que por tercera vez deshiciera las armas de las que tan necesitados estaban los reinos españoles.

De 1689 son las «Ordenanzas del Gremio de Cuchilleros de la ciudad de Toledo», que fueron sancionadas por el rey Carlos II y que se conservan actualmente en el Archivo Municipal de Toledo.

Hasta principios del siglo xviı las normas legales reguladoras del uso o abuso de las navajas utilizaban la socorrida expresión genérica de «y otras armas blancas cortas» después de mencionar los puñales, cuchillos, rejones y giferos. Pero poco a poco la navaja va adquiriendo plena autonomía, independencia y personalidad propia, y es en 1732 cuando pol primera vez en un auto del Consejo se mandó a los alcaldes de Corte que dieran «las providencias mas eficaces para recoger las navajas largas de muelle ó encaxe que vien de otros reynos, haciéndolas romper, y prohibiendo absolutamente el uso y fabrica de ellas, pena de ser castigados con todo rigor los contraventores».

El rey Fernando VI, en 1748, decreta la absoluta prohibición de armas blancas, con derogación de todo fucro en el uso de ellas, y así, en el apartado segundo de esta disposición dice: «Mando igualmente, que en qualesquier asiento, arrendamiento ó contrato que se hiciere con mi Real Hacienda, y en que se estipule el uso de armas prohibidas, se exceptuen siempre las blancas, pues las cortas de fuego, y las no prohibidas de toda 
especie bastan para el resguardo de las rentas Reales; de modo que, si por algun accidente no estuviere puesta en el permiso ó dispensacion del uso de armas prohibidas la excepcion ó limitacion de las blancas, se en ${ }^{-}-$ tienda como si estuviere expresada; y que así se hayan de entender todas las capitulaciones y asientos que actualmente estan executados con semejante licencia, aunque contengan la absoluta dispensación de armas prohibidas: en la inteligencia de que mi intención es, que los Ministros dē Rentas solo usen de fusil, escopetas, pistolas y espada.»

Más adelante el mismo rey Fernando VI, por bandos publicados en Madrid en 1749, 1751 y 1754, ordena «que ninguna persona, de qualquier estado ó condicion que sea, lleve ni use de armas blancas cortas, como puñal, rejon, gifero, almarada, navaja de muelle con golpe o virola, daga sola, cuchillo de punta chico o grande, aunque sea de cocina ni dé moda de faldriquera, pena al noble de seis años de presidio, y al plebeyo los mismos de minas; y que ningun maestro armero, tendero, mercader; prendero ni otra persona pueda fabricarlas, venderlas ni tenerlas en sus. casas y tiendas, ya fuesen fabricadas en la mi Corte, ó venidas de fuera de ella.»

«En Real Orden de 13 de marzo de 1753, consiguiente a consulta resuelta del Consejo de Guerra, se sirvió S. M. declarar comprehendidas en la prohibición del uso de armas cortas blancas las navajas de puntâ, pequeñas ó grandes, que sean de muelle, virola con buelta, relox u otro artificio que facilite la firmeza de la hoja armada.»

Carlos III, en una pragmática-sanción de 26 de abril de 1761, dice: "Conviniendo a mi Real servicio y bien de mis vasallos revalidar para todos mis reynos y señoríos, incluso los de Aragon y Valencia, Cataluña y Mallorca, las pragmáticas de 1663,82 y 91, y de 1713, 757, que son las leyes $8,9,10,11$ y 18 de este título, prohibitivas del uso de armas cortas de fuego y blancas; mando, se observen y cumplan en todo y por todo, y la prohibición del uso de dichas armas, como son pistolas, trabu$\cos$ y carabinas, que no lleguen a la marca de quatro palmos de cañon; puñales, giferos, almaradas, navaja de muelle con golpe ó virola, daga sola, cuchillo de punta chico o grande, aunque sea de cocina y de moda de faldriquera, baxo de las penas impuestas en dichas Reales pragmáticas; y son, a los nobles la de seis años de presidio, y á los plebeyos los mismos de minas; y a los arcabuceros, cuchilleros, armeros, tenderos, mercaderés, prenderos ó personas que las vendieren o tuvieren en su casa ó tienda, por la primera vez quatro años de presidio, por la segunda seis al noblè, y los mismos de minas al plebeyo, con las demas prevenciones y penas que se refieren en las citadas pragmáticas, las que en todo quedan en su. fuerza y vigor; y de ellas no se librarán los contraventores, aunque lleven las armas prohibidas con licencia de qualesquiera de mis Tribunales, Co- 


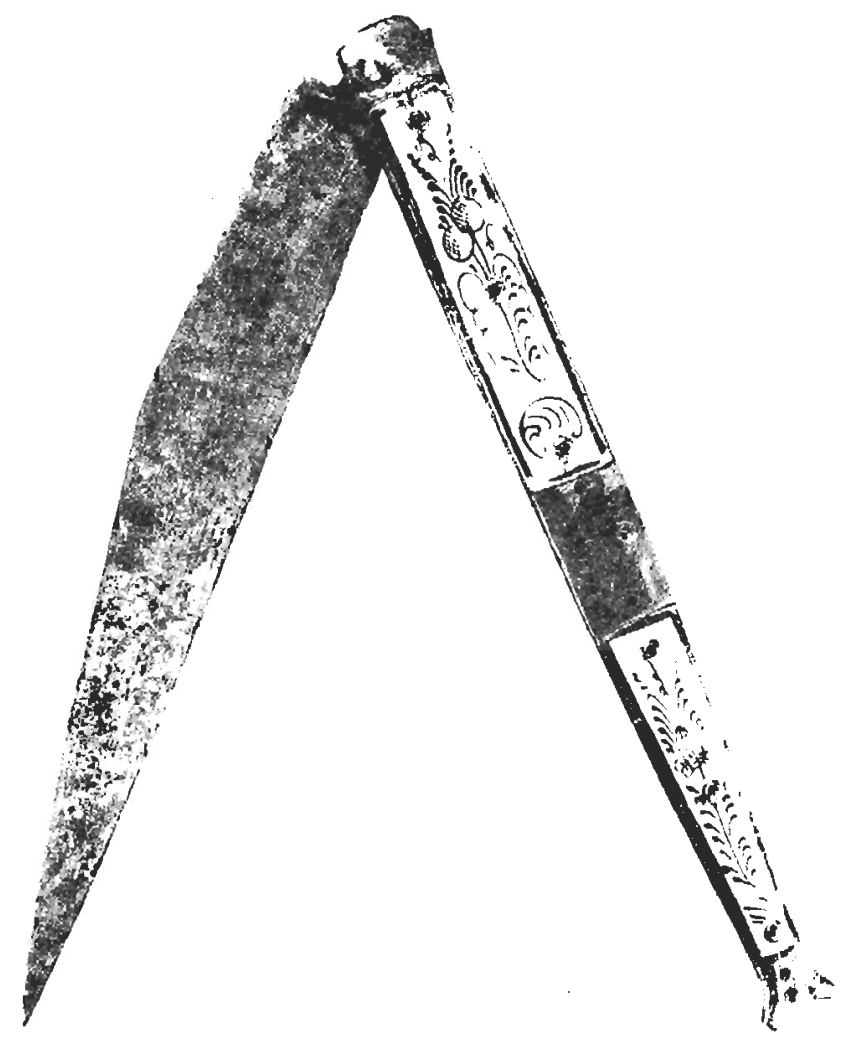

Fig. 26.-Navaja francesa. Véase Carálogo núm. 57.

$R 2068$

mandantes, Gobernadores ó Justicia, porque ninguna ha de tener otra autoridad que la de hacer observar y obedecer esta mi Real pragmática; por la qual, y por un efecto de mi Rcal confianza en la nobleza, de que no abusará de ella en pcrjuicio de la causa pública, permito solamente á todos los caballeros; nobles, hijos-dalgo de estos mis reynos y señoríos, en que son comprehendidos los de Aragon, Valencia, Cataluña y Mallorca, el uso de las pistolas de arzon, quando vayan montados en caballos, ya sea de paseo ó de camino, pero no en mulas ni machos, ni en otro carruage alguno, y en trage decente interior, aunque sobre él lleven capa, capingot ó redingot con sombrero de picos; pero quedando en su fuerza la 
FIG. 27.-Navaja francese. Véase Catálogo núm. 61.

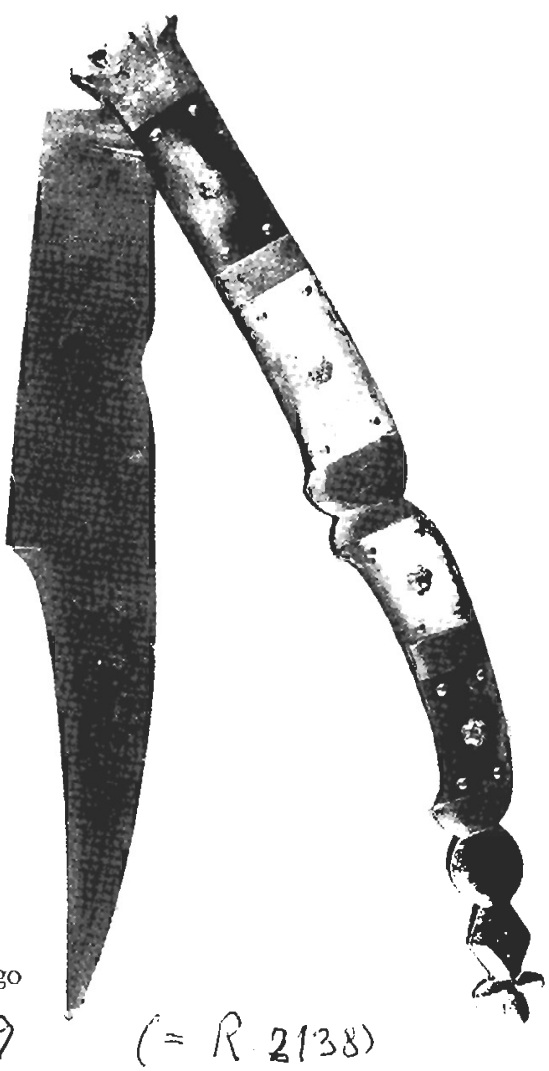

prohibición y sus penas para el uso de pistolas de cinta, charpa y faldriquera, y para el que traxere las de arzon sin las expresadas circunstancias, aunque sea noble. $Y$ asimismo prohibo, que los cocheros, lacayos, y generalmente qualquier criado de librea, sea de quien fuese, sin mas excepcion que los de mi Real Casa, traigan á la cinta espada, sable ni otra ninguna arma blanca, baxo las penas arriba expresadas contra los que usan de armas blancas prohibidas. Todo lo qual quiero, se observe y guarde como ley y pragmática-sanción hecha y promulgada en Córtes; y mando que se publique en Madrid, y en las ciudades, villas y lugares de estos mis reynos y señoríos, por convenir así á mi Real servicio, y ser esta mi Real voluntad».

En la actualidad, la norma legal aplicable a la tenencia y uso de la navaja está recogida en el Reglamento de Armas y Explosivos, promul- 
gado por decreto de 27 de diciembre de 1944 (Boletin Oficial del Estado del 19 de enero de 1945), en cuyo artículo 47, al hablar de las armas prohibidas, se dice: «Se prohíbe la circulación, importación, venta, uso y tenencias de las siguientes: (...) navajas cuya hoja puntiaguda exceda de once centímetros, medidos desde el reborde o tope del mango que la cubra hasta la punta.»

\section{Cómo se llevaba}

Lo primero que se nos ocurre pensar es que la navaja se llevaba en el bolsillo igual que en nuestros días, pero al parecer en épocas pasadas la vestimenta al uso no iba provista de los abundantes bolsillos con que hoy

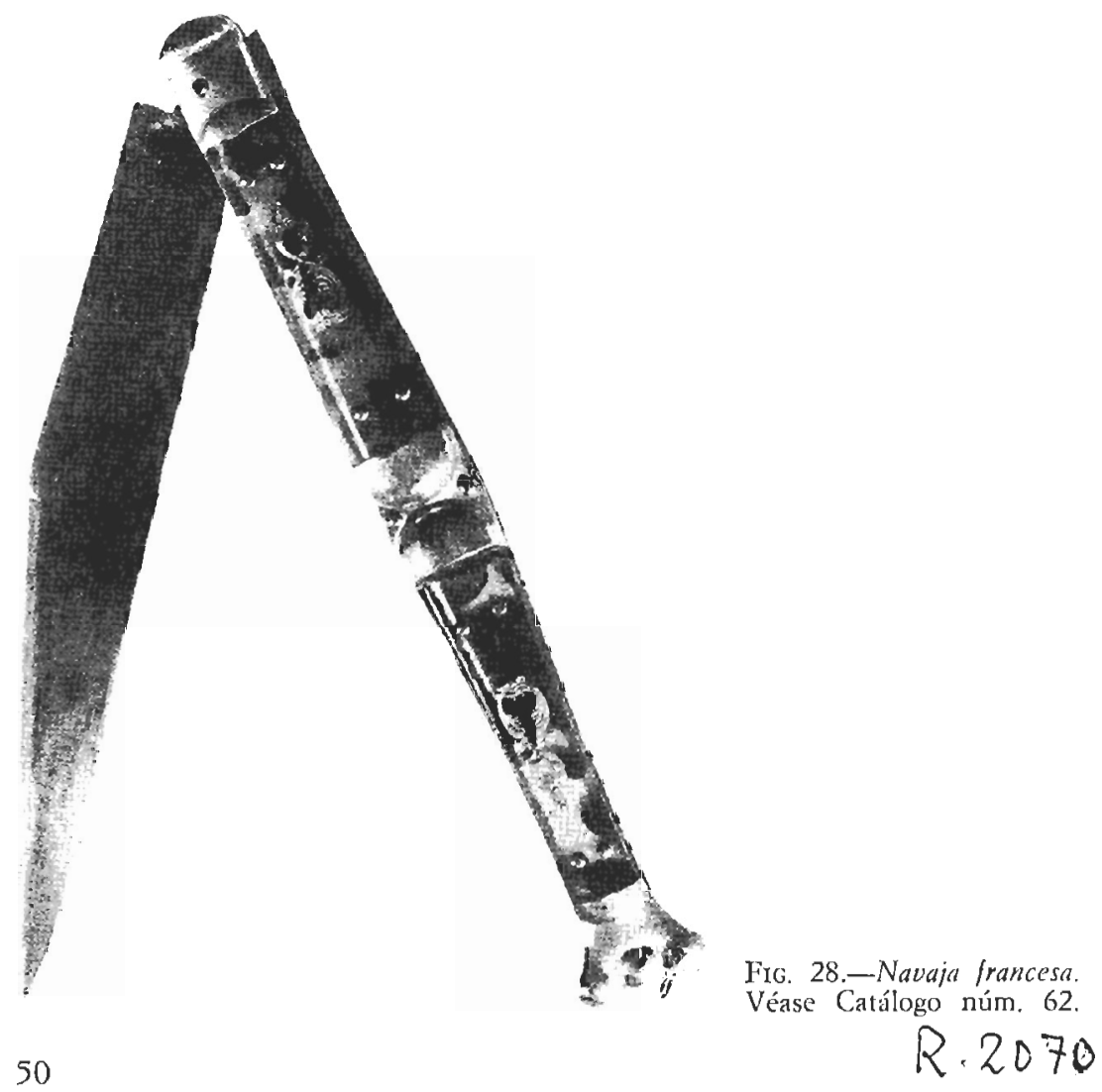


contamos. Su gran tamaño facilitaba el que se llevara en la faja, a la espalda o a un lado, dentro del cinturón o sujeta a la cintura o chaleco con algún cordoncillo o cadena como indican ciertos orificios de que van provistas algunas de ellas.

\section{La navaja en la liga}

Mucho se ha hablado de la íntima presencia de la navaja en la liga de la mujer española. Pero yo, que creo sinceramente que algunas mujeres («majas») efectivamente la llevaron en una determinada época, estimo que el uso no fue ni general ni mucho menos secular. Ciertamente, el hecho en sí, por lo original, lo insólito, por su tipismo y color local, llamó la atención, cautivó y se propaló por algunos escritores españoles y muchos extranjeros.

Morel-Fatio ${ }^{36}$, que al parecer estudió el tema a fondo, explica cómo el que la mujer llevara una navaja o puñal en la liga era algo común a los países (europeos) mediterráneos, y así cita al mariscal De Tesse, al presidente de Brosses, Alfieri, D. G. Rossetti y otros quienes dejaron constancia del hecho. Lo que a su juicio ocurrió fue que los soldados de Napoleón, tras su estancia en España, propagaron por Europa este sorprendente hecho con el que se enfrentaron insospechadamente en más de una ocasión, extrapolándolo y generalizándolo a todas las mujeres españolas.

Blaze, Merimée, Edouard de Nangis, Alfred de Vigny, Dumas, Desbarolles, Tanski, J. M. Blanco-White, Ford y Davillier han sido los escritores que más han contribuido a dejar constancia de tan curiosa costumbre ${ }^{37}$.

Citemos, por último, algunas leyendas como «Prendida en la liga defiendo a mi dueña» y «En la liga una navaja / y la mano en la cadera / va vertiendo sal la maja», que son frases que, grabadas en la hoja, dejaron constancia de este hecho singular.

\section{Marcas}

Se recogen a continuación una serie de marcas o punzones - pertenecientes a mi colección en su inmensa mayoría - sin más indicaciones al

3o I.a Gallophobie espagnole, Bibliothèque Universelle et Revue Suisse, 1915, y El puñal en la liga, en «Revue de Littérature Comparée», 1921.

"Nota 8 al capitulo VII de Davillier, op. cit., pág. 1079. 
respecto, habida cuenta de que ya vienen, en cierta medida, comentados en su ficha correspondiente del Catálogo. Los punzones de marca comenzaron a usarse en España a partir de los primeros años del siglo xvi.

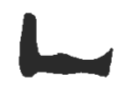

M
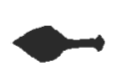

No 8

SOISOMA

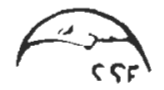

Qi

N? 16

NO 18

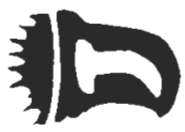

NN 10

NO 11

No 9
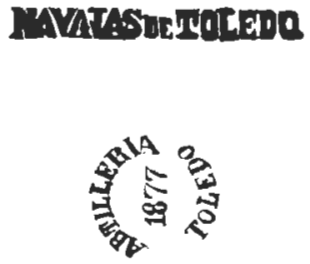

No 31

No 33

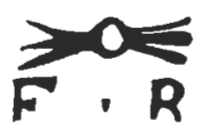

N2 34

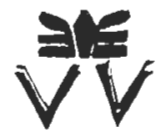

No 24

NQ 25

NQ 35

$$
\text { R.2071 }
$$

52 


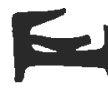

NO 30

NQ 37

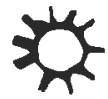

VLLEGA

ongaet

NO 39

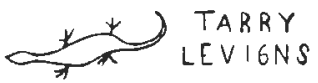

\section{LACASSIS}

No 11

Q.

N) 46

A OLORON

PIQUE

A OLOROI

HAUDEVIL'T

- Ficarantzado

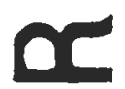

FORTUN

'ARAgOT

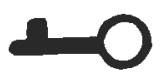

N) 51

Nบ 50
$-O$-6IRODIAS

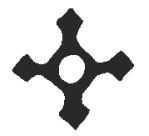

NQ $56,57,58$ $\because: 2 \quad 55$

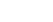




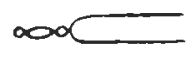

BEAUVOIR

MOREL COUS ON

- IQUE

$\underset{\text { PARIS }}{\operatorname{EdMONGIN}}$
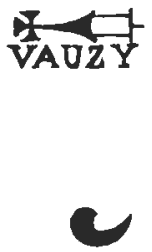

10

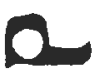

№ 71 .

F.HERBERZ

SOLINGEN

No 76

\&W HANOCCR

\& SONS

SHEFTIELD

(4) E H.A

No 73

N12 69

DOCH

NO 74

No 75

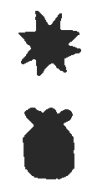

$\mathbf{R}$
Nㅡㅇ 81 


\section{Ejemplares en museos españoles}

Tal como este título indica, en el presente apartado nos referimos a algunos de los museos, muy pocos, tan sólo a aquellos que hemos visitado personalmente o de cuyas existencias de navajas podemos realmente responder.

A través de este recorrido por los museos veremos cómo la navajología ha inquietado muy poco a los investigadores amantes de las armas y del arte popular, sin que exista una sola navajoteca ni tan siquiera una muestra digna y representativa de una artesanía e industria que llegó a tener tan grande esplendor en España.

En la Real Armería de Madrid no existe ninguna pieza ni expuesta ni en los depósitos de dicha institución. Igualmente ocurre con el Museo Naval y con el de Artes Decorativas de Madrid, con el Museo Cerralbo y con el Lázaro Galdiano, tan rico este último en otras armas blancas cortas y largas.

En el Instituto Valencia de Don Juan existe tan sólo una navaja, preciosa por cierto, toda ella de acero - a excepción de unos adornos en forma de lazos, en latón-, que tiene decoradas sus cachas magníficamente a base de unos relieves con motivos de armería soberbiamente ejecutados. La hoja es lisa y el cierre de anilla. Tiene una marca o punzón que no se lee y su longitud es de $18 \mathrm{~cm}$. A mi juicio, es del siglo xIX, y al parecer llegó a este Instituto alrededor del año 1928, probablemente donada por M. Rebull. No figura en el Catálogo de armas de Florit y Sánchez Cantón debido a su incorporación posterior.

En el Museo Municipal de Madrid, cerrado al público desde hace bastantes años, no así al investigador, existe tan sólo una navaja en una de las vitrinas de la sala del Dos de Mayo que procede del Archivo de Villa, Sección Museo, y que se llevó allí en 1926. Es prácticamente igual a la número 66 de mi Catálogo y tiene en su hoja la marca Riberon, siendo de una longitud de $24 \mathrm{~cm}$. aproximadamente. En las cachas tiene la fecha de 1808 grabada por su propietario, no por el fabricante, que sin duda era francés, y a juicio de los expertos de dicho Museo procede de las requisas efectuadas al pueblo de Madrid por las tropas napoleónicas.

En el Museo del Ejército existen tan sólo tres navajas. Dos de ellas, muy sencillas y sin valor aparente alguno, se muestran en una panoplia situada en el bar. La otra, larguísima, de latón, con dibujos moriscos, recuerda a la número 21 de mi Catálogo y está expuesta en la Sala de la Guardia Civil. En la hoja se puede leer la siguiente leyenda: «Si esta víbora te pica, no vayas por ungüento a la botica.» Tiene la referencia 
número 49 y un cartelito adjunto dice: «Recogida por la Guardia Civil en la guerra de Cuba», perteneciendo, por tanto, al siglo XIX.

A primera vista, el Museo Arqueológico de Albacete debería contar con una amplia gama de navajas de diversos tipos y épocas, habida cuenta de la raigambre y fecunda tradición navajera que tienen no sólo la capital, sino también la provincia. Pero por esas ironías que la vida ofrece ello no ocurre así, ni mucho menos. El Museo, actualmente en período de traslado, tiene en una vitrina - no expuesta al público - tres únicas navajas. Dos de ellas carecen de interés navajológico y la tercera es una navaja de espejillos (cuatro) con un dibujo calado en forma de corazón con el fondo de lentejuelas de cobre color rojo. Mide $22 \mathrm{~cm}$., es de latón, hueso y acero y la hoja tiene grabado el típico dibujo vegetal de la navaja española.

Tampoco existe nada en el Museo de Armas Blancas de la Fábrica de Armas de Toledo, y esto sorprende no poco al amante de estas reliquias históricas, sobre todo cuando se piensa que allí se produjeron piezas que están, por lo perfecto de su elaboración, entre las mejores con las que cuenta el acervo navajístico español. Los ejemplares números 29 y 31 de mi Catálogo, elaboradas allí, hablan por sí solos de la exactitud de este criterio. Don Santiago Albillos, director y alma del Museo, nos indicó amablemente que sí existe una navaja en los fondos de este Museo; pero se trata de un tipo especial, de usos múltiples, fabricada por esa entidad estatal en 1958 para las tropas paracaidistas, por lo que cae fuera del objetivo de este trabajo y forma parte de otro tema, del que nos ocupamos ya al hablar del carácter civil de la navaja española.

En el Museo del Pueblo Español de Madrid existen varias navajas, de las que sólo tienen interés media docena. A mi juicio, algunas de las que figuran en los depósitos del Museo son de superior valor a las expuestas al público en la vitrina correspondiente. Sobresale la señalada con la Ref. 12688, semejante, aunque sea bastante más reducido su tamaño, a la número 36 de mi Catálogo y se halla en peol estado de conservación. La referenciada con el número 13426 , que es de hueso y carey, tiene $15 \mathrm{~cm}$. de largo y sus cachas representan, muy bien labrado, y con toda probabilidad, a un oficial del ejército. Las marcas de las más sobresalientes de las restantes navajas son: Ed. Mongin (dos), Riberon (con un «viva la libertad» dentro de un bonito dibujo de la hoja), C. A. y Girodias.

Dentro de los simpáticos y valiosos objetos que contiene el Museo del Cau Ferrat — siguiendo en esta ocasión lo que dice su Catálogo ${ }^{38}$-, existen dos navajas que, según se indica, pertenecen a los siglos XVI y

${ }^{38}$ Guía del Museo del Cau Ferrat, Publicaciones de la Junta de Museos de Barcelona, 1940 , págs. 50 y 59. 
XviII. En la figura 29 se recoge la navaja de finales del siglo xvI, que es de cortas dimensiones, toda ella de acero, con adornos que atraviesan las cachas y un mecanismo que sirve para pesar. Como puede verse, es muy semejante a algunas de las primeras mencionadas y reproducidas aquí del Museo Arqueológico Nacional.

En el Museo Arqueolúgico Nacional existen varias navajas de manifiesto interés navajológico de las veintinueve que posee. Tres de ellas son recogidas en la figura 30 , todas de acero, de muy pequeño tamaño - la más larga mide $8 \mathrm{~cm}$.-resultando difícil situar la época a que las mismas pertenecen; probablemente sean de finales del siglo XVI, a juzgar por el perfil de las cachas.

En la figura 31 aparecen dos navajas. La de la izquierda es toda ella de acero - a excepción de la laminilla de latón del corazón central--, de gran tamaño, pues mide $25,5 \mathrm{~cm}$. y tiene una «R» como marca. La otra navaja, Ref. 6195, es muy original, pues aparte de que la base de las cachas representa un animal quimérico y tiene unos dibujos vegetales muy decorativos, en su parte superior posee un gancho girable y en la parte inferior del eje de las guardas una pequeña anilla, que sirve para pesar objetos de menor cuantía, gracias a un muelle interior y a una barrita graduada que sale hacia afuera al ejercer presión sobre la anilla; tiene como punzón una especie de coma ancha y mide $11,5 \mathrm{~cm}$.

Semejante a esta última navaja mencionada, existe otra de cachas de latón, de una sola pieza y dibujos grabados, con un clemental aparatito para pesar parecido al descrito en la navaja anterior; tiene $11 \mathrm{~cm}$. de longitud y una cruz de anchos brazos como marca. Muy similar a ésta, existe otra, aunque sin dibujos en las cachas y algo más pequeña de tamaño.

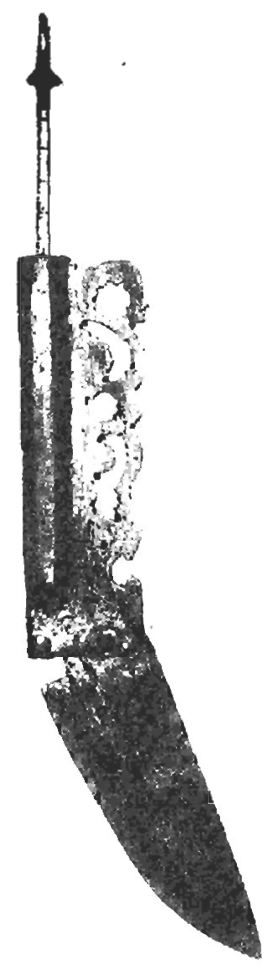

F1G. 29.-Navaja de $/ i$ nales del siglo XVI Gran Salón del Museo del Cau Ferrat de Sitges, Barcelona).

«En Albazete 1789» es la inscripción que tiene una navaja existente en este Museo, que llama la atención por lo perfecto de los calados de la hoja y los dibujos que adornan la misma. Tiene $15,5 \mathrm{~cm}$., es de asta de toro negra y en la hoja se puede leer «Viva mi dueño y señor». 
No podía faltar aquí la típica navaja de dimensiones desmesuradas - $70,5 \mathrm{~cm}$.—, que no debía tener otra finalidad que la puramente decorativa. Las cachas están muy elaboradas, a base de dibujos y formas que recuerdan a las de la número 27 del Catálogo, y son de latón y hueso; la hoja recoge tres leyendas, una detrás de la otra, y fue fabricada, tal como en ella se dice, en Alcázar de San Juan en 1892.

Hay una navaja que tiene especial interés por su cierre de secreto. Se trata de un ejemplar de pequeñas dimensiones $(11 \mathrm{~cm}$.), de latón, cobre y asta negra, que tiene grabadas en los extremos inferiores de las cachas dos esferas de reloj con una saeta cada una, necesitando una de ellas - la
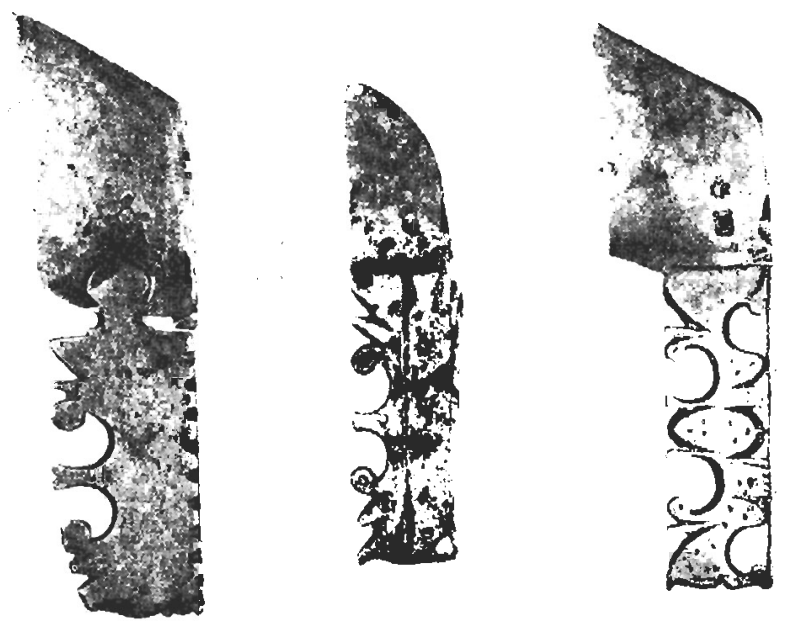

FIG. 30.-Navajas de finales del siglo XVI (Depósitos del Museo Arqueológico Nacional, Madrid).

$$
\text { R.2074 }
$$

otra es fija- situarla en la debida hora —en la presente navaja es a las tres- a fin de poder abrirla. Existe otro ejemplar semejante al precedente, aunque más sencillo.

Hay tres navajas, de 51,26 y $24 \mathrm{~cm}$., similares a las números 21 y 22 del Catálogo, que también tienen el interior de las cachas de madera, dibujos grabados y dos de ellas con leyendas en la hoja y cierre de ventana.

Cuenta el Museo con una pequeña navaja de espejillos, otra de secreto de $14 \mathrm{~cm}$. semejante en cuanto a su mecanismo de apertura a la nú- 
mero 41 de este Catálogo, una de cinco usos, toda ella de acero, con extraños dibujos nielados en latón, aparte de otras navajas más frecuentes y populares, aunque no menos lucidas algunas de ellas por los adornos de las cachas, y grabadas con motivos vegetales que adornan las hojas.

Fig. 31.-Navajas (Depósitos del Museo Arqueológico Nacional, Madrid).

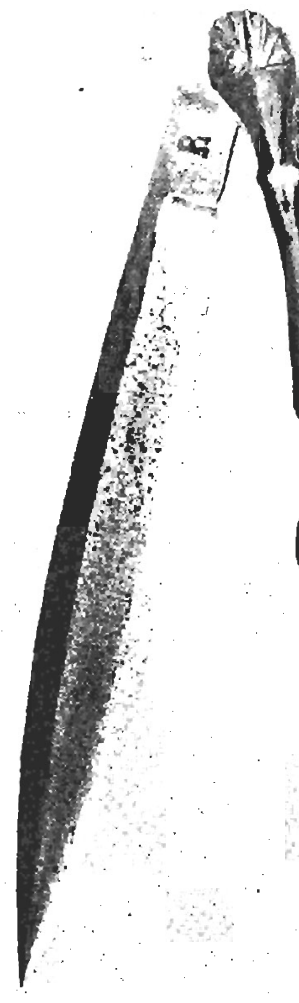<smiles>[R20][18O]</smiles>

Finalmente, citamos las tres navajas expuestas en una vitrina de la exposición. La de la izquierda es una bonita y pequeña navaja $(10 \mathrm{~cm}$. aproximadamente) de latón, de forma más o menos cilíndrica, aunque 
disminuyendo mucho su diámetro en los extremos, moldurada longitudinal y transversalmente y con algo de asta color marrón claro en el centro. La hoja posee un calado sencillo y carece de mecanismo especial de cierre.

La central es toda ella de acero, con dibujos nielados en latón, mide unos $18 \mathrm{~cm}$., su cierre es de varilla, no tiene marca y parece realmente antigua, sin que pueda precisar más en este sentido.

La de la derecha es muy semejante a las tres navajas de la figura 30 , pero sus cachas son de latón y están caladas, formando unos bonitos dibujos en forma de corazones y triángulos. Mide $7 \mathrm{~cm}$. aproximadamente.

Según se indica en la misma vitrina, la mayoría de las piezas que allí se exhiben (tijeras, puñales, navajas, etc.) proceden de las colecciones Rico y Sinobas y Gabriel y Galán.

\section{Escasez de ejemplares}

Algunas veces nos hemos preguntado a qué se deberá la ausencia tan grande que existe de navajas, de este instrumento tan abundante en otros tiempos. Hoy se pueden contemplar muy fácilmente y adquirir sin dificultad espadas, sables, dagas, puñales, machetes antiguos, etc., y no digamos nada de las armas de fuego; pero navajas, iqué difícil resulta! Las hay, pero escasísimas y en general deterioradas, rotas, incompletas y sin valor hístórico o artístico que las haga realmente de interés.

Las razones de esta manifiesta escasez no pueden ser, a nuestro juicio, más que dos:

1. ${ }^{a} \quad$ Su uso. La navaja, por definición, está concebida para una trabajo arduo y algunas veces violento: cortar y pinchar, y éstas son dos operaciones con las que todo instrumento, por buenos quc sean los materiales con los que está fabricado, acaba gastándose, mellándose y rompiéndose. No olvidemos que los aceros de aquellos tiempos ni eran tan buenos como los de hoy ni todas las navajas estaban hechas en prestigiosas fraguas de excepción. Si a csto añadimos lo frecuente que era el practicar el lanzamiento de navaja, con todo lo que ello supone, no sólo por su torpe caída al suelo al no acertar adecuadamente el objetivo, sino por el simple hecho de clavarse violentamente, tendremos una explicación lógica de su desaparición.

Hasta aquí hemos hablado tan sólo de su uso, pero no digamos nada de cuando existe abuso o uso indebido: entonces la navaja es seguro que no pasa a la postcridad. 
2. Las disposiciones legales. Frases recogidas de las ordenanzas, autos, pragmáticas y leyes de nuestros reyes, al referirse a las medidas a tomar contra los que infringían las disposiciones sobre tenencia de navajas, hablan por sí solas: «... haciéndolas romper...»; «... demoliendo las que estuvieran hechas...»; «... recogiendo y quebrantando...»; «... sacassen del Reino en el término preciso de 15 días siguientes...»; «... rompiessen las puntas haciéndolas redondas o romas...»; «... las rompan o saquen del Reyno...». La verdad es que así no hay manera de conservar nada.

Finalmente, cabría añadir como causas destructoras la implacable y nefasta acción de la humedad por un lado y la conservación, demasiado frecuente, en pésimas condiciones: enterradas o escondidas en tejados durante las guerras civiles, etc., por otro.

Fig. 32.- «Pelea con navajas, de Picolo (Colección particular, MaUrid).

$$
\text { R. } 2077
$$

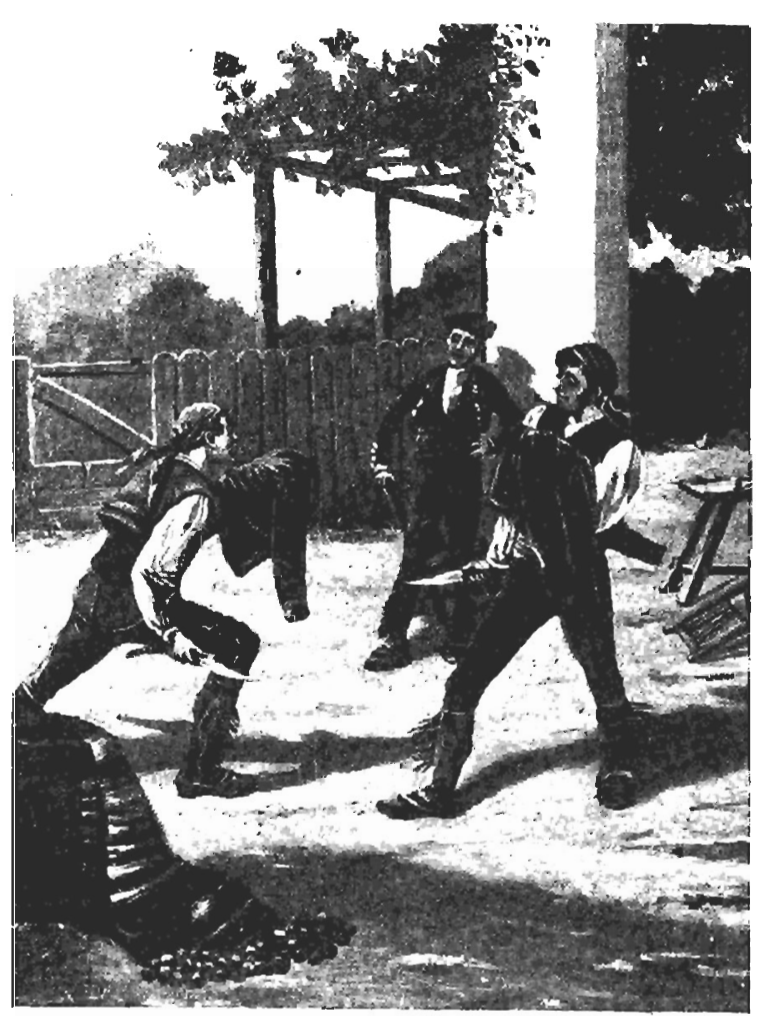

61 


\section{Textos literarios sobre la navaja}

Como no podía menos de ser, la navaja ha sido objeto de numerosos escritos debidos a consagradas y afamadas plumas.

Aparte los esforzados viajeros románticos que de punta a cabo recorrieron nuestra Península en el pasado siglo, como Teófilo Gautier, el Barón Charles Davillier, Laborde, etc., y que luego dejaron constancia de sus aventuras y desventuras en sus escritos, son todavía muchos más los escritores españoles que cantaron a esta noble y bellísima arma blanca que es la navaja.

Sólo por citar a algunos escritores, mencionaremos a Azorín, cuando explica cómo en la anacronicidad de la navaja de Albacete reside su verdadero encanto.

José María Pemán:

$$
\begin{aligned}
& \text { ¿La navaja tiene filo } \\
& \text { para el odio o para el pan! }
\end{aligned}
$$

Juan Alcaide:

$$
\begin{aligned}
& \text { Ciudad de la sonrisa adolescente, } \\
& \text { meccano de la limpia carcajada, } \\
& \text { Walt Whitman te llamó su enamorada } \\
& \text { pasando una navaja por su frente. }
\end{aligned}
$$

Francisco Belmonte:

¿Navaja! Temido acero

de albaceteña raigambre:

si algo matas, es el hambre

del bonrado navajero.

J. J. García Carbonell:

El buen pan de La Roda

mi padre hacía pedazos,

el pan grande en el pecho

la navaja en la mano.

¿Navaja de mi padre,

cuántas cosas hacías en su mano!

\section{2}




\section{Federico García Lorca:}

En la mitad del barranco

las navajas de Albacete, bellas de sangre contraria relucen como los peces.

Una dura luz de naipe

recorta en el agrio verde, caballos enfurecidos

$y$ perfiles de pinceles.

En la copa de un olivo

lloran dos viejas mujeres.

El toro de la reyerta

se sube por las paredes.

Angeles negros traían

pañuelos y agua de nieve.

Angeles con grandes alas

de navajas de Albacete.

Juan Antonio el de Montilla

rueda muerto la pendiente

su cuerpo lleno de lirios

y una granada en las sienes.

Ahora monta crux de fuego,

carretera de la muerte.

Agustín Sandoval:
Albacete, pequeña
capital provinciana:
Cusando yo vengo a $t i$
como a una novia blanca,
in recuerdo de ayer
me entristece y me abrasa
$y$ siento como si
me birieran tus navajas...

Francisco Cutanda:

Todo el inundo te compra sin pereza, todo el mundo te aprende y te decora, todo el mundo te observa con llaneza.

Tu eres reina legitima y señora 
de este tu pueblo fiel reconocido, que tu favor y protección implora.

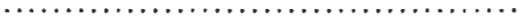

Por solas estas gracias merecias, ¿Navaja!, gratitud, bumilde cullo y alabanzas más altas que las mias. 


\section{A T A L O G O}


N. 1

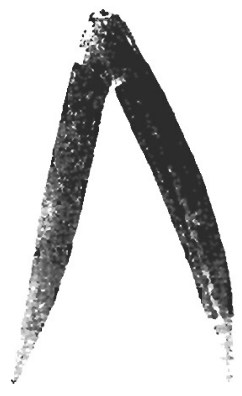

N. 2

N." 3

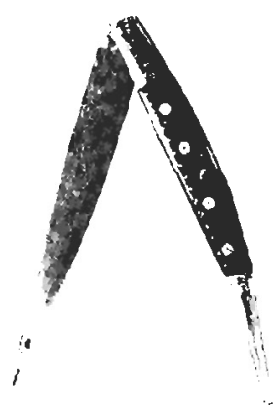

Cacbas: De asta de toro negra con incrustaciones de latón en tres líneas longitudinales, la central con orificios casi semicirculares y lentejuelas de cobre en su interior, las laterales de pequeños clavos. Los extremos son también de latón con dibujos sencillos.

Hoja: Con dibujo típico de color rojo.

Cierre: De ventana con cinco dientes.

Longitud: $23 \mathrm{~cm}$.

Epoca: Siglo xix.

$$
32178
$$

Cacbas: De asta de toro blanquecina e incrustaciones de latón en tres líneas longitudinales, la central con orificios casi semicirculares y lentejuelas de cobre en su interior; las laterales, de pequeños clavos. Los extremos son también de latón con dibujos sencillos.

Hoja: Con dibujo típico de color rojo hoy casi desaparecido.

Cierre: De ventana con cuatro dientes.

Longitud: $24,5 \mathrm{~cm}$.

Epoca: Siglo xix.

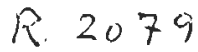

Cacbas: De asta de toro negra y latón. Tiene incrustados cuatro círculos de asta blanca y dos líneas exteviotes de pequeños clavos de latón. Los extremos son también de latón con dibujos sen. cillos.

Hoja: Con dibujo típico muy sencillo en rojo y la leyenda «Soi defensa de mi dueño».

Cierre: De ventana con tres dientes.

Longitud: $22 \mathrm{~cm}$.

Epoca: Siglo $\mathrm{xIx}$.

$$
\text { R. } 2080
$$


N. 4

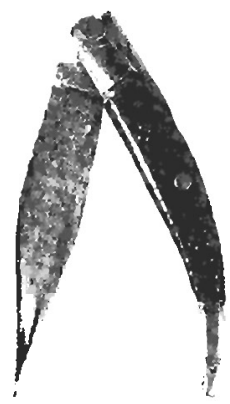

Cachas: De asta de toro negra teniendo incrustados pequeños clavos de latón; los extremos son de latón con dibujos sencillos.

Hoja: Con dibujo típico sencillo. El talón forrado de latón.

Cierre: De varilla.

Longilud: $15 \mathrm{~cm}$.

Epoca: Siglo xix. R2081

N. 5

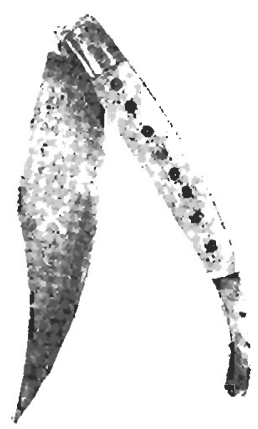

Cacbas: De asta de toro blanca con ocho círculos de asta negra incrustados. Los extremos son de latón con dibujos muy sencillos.

Hoja: Ancha, con cruces perforadas, dibujos de puntos y la fecha de julio 1877. Tiene incrustados tres pequeños círculos de latón en la parte central.

Cierre: De ventana.

Longilud: $24 \mathrm{~cm}$.

Epoca: 1877. R. 2082
N. ${ }^{\circ} 6$

68

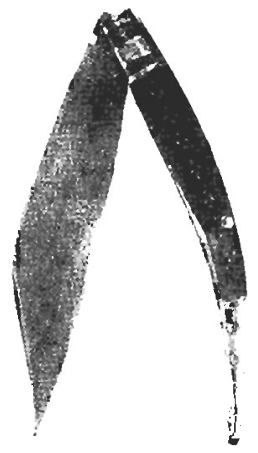

Cachas: De asta de toro negra con incrustaciones de pequeños clavos de latón formando ocho rombos; los extremos son de latón con dibujos grabados paralelos entre sí.

Hoja: Lisa y ancha.

Cierre: De ventana con seis dientes.

Longitud: $27 \mathrm{~cm}$.

Epoca: Siglo XIX.

Otros datos: Especialmente bien conservada. P. 2083 


\section{N. 7}

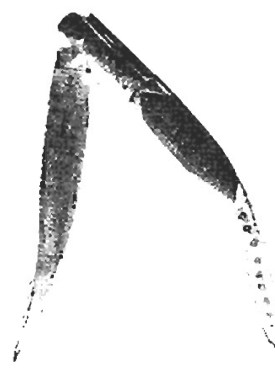

N. 8

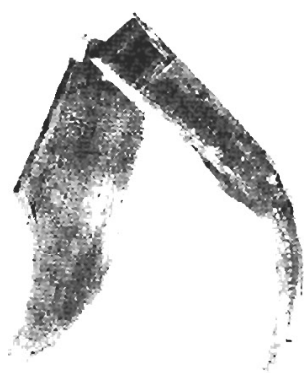

N.2 9

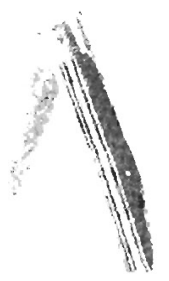

Cacbus: De asta de toro marrón-negra con pequeñísimos clavos de latón; hueso en su parte inferior con clavos de latón, y de latón también el extremo superior con dibujos varios.

Hoja: Estilizada. Con dicciocho muescas en el recazo. La base está forrada de latón. Dibujo floral deteriorado. Leyendas: «Viva el honor de mi dueño», y por la otra cara, «Defensa de mi dueño».

Cierre: De varilla.

Marca: Como una «L» al revés pintada de t'ojo.

Longitud: $20,5 \mathrm{~cm}$.

Epoca: Principios del siglo xix. $R .2084$

Cachas: De asta de toro color pardo con diecinueve clavos de latón y los extremos también de latón. La parte inferior tiene una curva muy acentuada.

Hoja: Muy ancha y curva. Sin dibujos. Tiene una muesca para facilitar la apertura.

Cierre: De ventana.

Marca: Tíene un árbol en sentido horizontal y una M mayúscula.

Longitud: $19 \mathrm{~cm}$.

Epoca: Siglo xix.

Otros datos: Tiene una forma que recuerda a las capaoras albaceteñas.

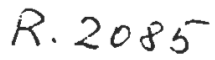

Cachas: De asta de toro negra, latón con dibujos grabados muy elementales en los extremos y en su eje longitudinal; tiene dos cordoncillos de cobre a los lados del eje.

Hoja: Lisa.

Cierre: De lengüeta.

Marca: Solsona.

Longitud: $28 \mathrm{~cm}$.

Epoca: Principios del siglo xx. R. 2086 
N." 10

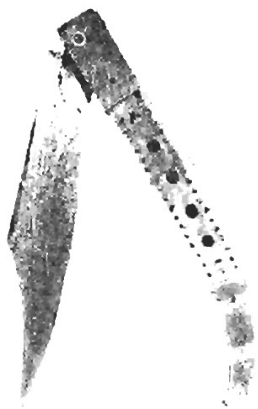

Cachas: De hueso con cuatro agujeros longitudinalmente situados y otros muy pequeños a ambos lados. Los extremos son de latón con grupos de rayas paralelas.

Hoja: Lisa.

Cierre: De varilla.

Marca: Tiene una media luna en forma de perfil humano.

Longitud: $16 \mathrm{~cm}$.

Epoca: Siglo xix. R. 2087

N." 11

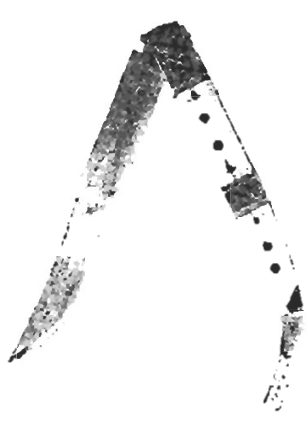

Cacbas: De hueso amarillento con cuatro agujeros grandes y muchos pequeños que enmarcan a éstos. Los extremos y la parte central son de latón con pequeños orificios con laminillas de cobre.

Hoja: Lisa.

Cierre: De ventana.

Marca: Una S horizontal.

Longitud: $21 \mathrm{~cm}$.

Epaca: Siglo xix.
N. ${ }^{\circ} 12$

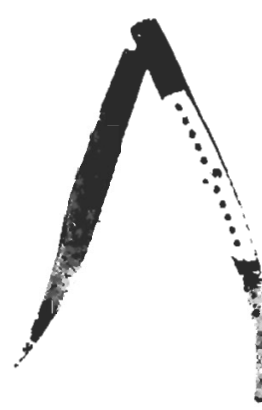

Cachas: De hueso, con nueve agujeros, que tienen en el fondo una laminilla de cobre; los extremos que son de latón están rayados toscamente.

Hoja: Lisa, muy estrecha y fusiforme.

Cierre: De varilla.

Longitud: $22,5 \mathrm{~cm}$.

Epoca: Siglo xix. 
N." 13

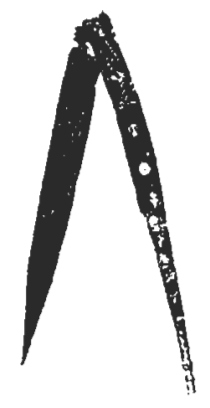

Cacbas: De latón muy labrado con motivos que recuerdan los hispano-árabes. La parte central es de asta de toro negra con tres círculos, el central de hueso y los laterales de latón.

Hoja: Lisa y estrecha.

Cierre: De ventana, con un perfil moldurado en los laterales superiotes de la varilla. Tiene tres dientes.

Longitud: $31 \mathrm{~cm}$.

Epoca: Siglo xviır.

R.2090

N. ${ }^{0} 14$

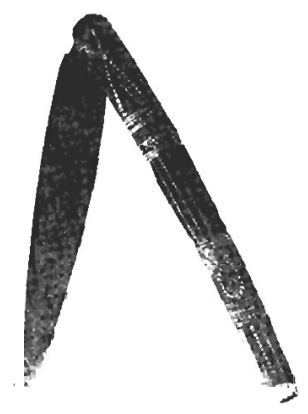

Cacbas: De latón, con dibujos que recuerdan ciertos motivos decorativos hispano-árabes y asta de toro negra con tres barras de latón longitudinalmentc situadas.

Hoja: No parece sea la original.

Cicrre: Sin mecanismo especial.

Longitud: $20 \mathrm{~cm}$.

Epoca: Siglo xvirr.

R. 2091

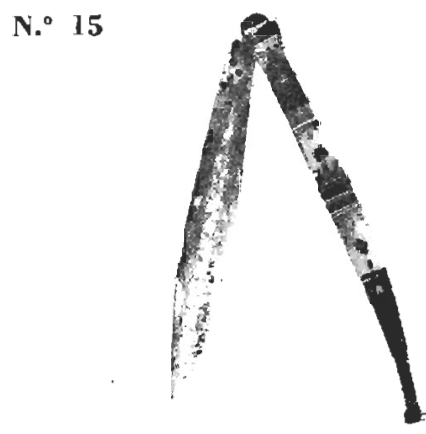

Cacbas: De asta de toro blanca y negra, latón y cobre, con círculos incrustados en el asta.

Hoja: De acero y refuerzos de latón en su base. Tiene de latón tres círculos grandes y seis pequeños incrustados en el centro de la hoja. Leyenda: «No me abras sin razón ni me cierres sin honor.» Línea fusiforme. Tiene algunos adornos grabados.

Cierre: De varilla.

Longitud: $27 \mathrm{~cm}$.

Epoca: Siglo xvin. 
N. ${ }^{\circ} 16$

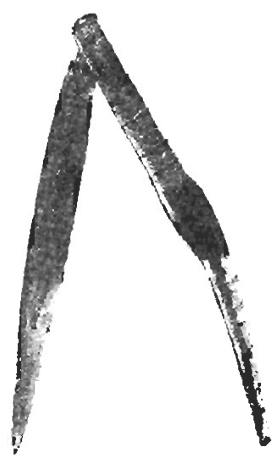

N. ${ }^{\circ} 17$

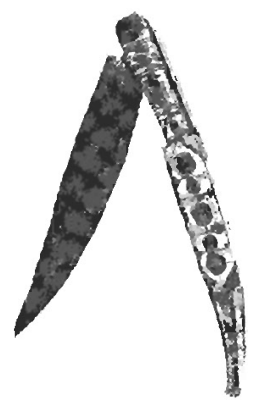

N. ${ }^{\circ} 18$

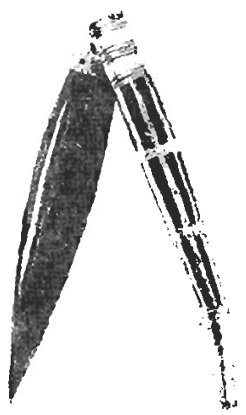

Cacbas: De latón con dibujos rectilíneos; la parte superior es cilíndrica; la parte central es de madera color castaño igual que todo el interior. En el extremo inferior tiene un orificio que la atraviesa.

Hoja: De forma fusiforme.

Cierre: Sin mecanismo especial.

Marca: Una J horizontal con ílamas en la parte supcrior.

Longilud: $26,5 \mathrm{~cm}$.

Epoca: Siglo xvin.

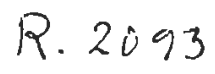

Cachas: De latón muy labrado a base de círculos muy pequeños y dibujos rayados; hueso con cinco espejillos, tres grandes y dos pequeños.

Hoia: De acero con ocho incrustaciones circulares de latón, once mucscas en el recazo, dibujos hoy perdidos y la leyenda "Viva el honol de ni dueño».

Cierre: De varilla.

Longilud: $18 \mathrm{~cm}$.

Epoca: Siglo xvir.

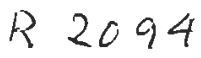

Cacbas: De asta de toro negra-marrón y latón labrado en sus extremos y a lo largo de las cachas altcrnando con cordoncillos de latón hoy perdidos en su mayoría.

Hoja: Muy ancha con dibujo desaparecido; con una larga y amplia hendidura; la base recubierta de latón.

Cierre: Sin mecanismo especial.

Marca: R R.

Longitud: $23,5 \mathrm{~cm}$.

Epoca: Fines del siglo xvir. 
N." 19

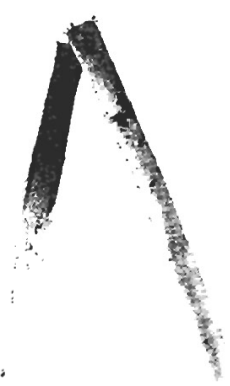

N. ${ }^{\circ} 20$

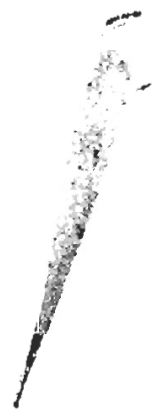

N. ${ }^{0} 21$

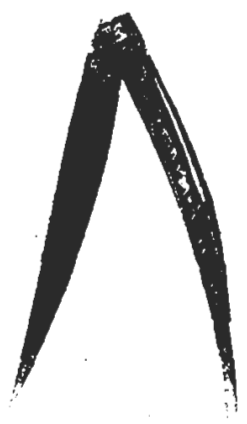

Cachas. De latón con dibujos sencillos grabados y acero en la parte superior. De líneas exteriores prácticamente paralelas. Muy estrecha de cuerpo.

Hoja: Muy estilizada, con dibujo típico sencillamente ejecutado y algo desaparecido.

Cicrre: De varilla.

Longilud: $22 \mathrm{~cm}$.

Epoca: Primera mitad del siglo xvm.

$R .2096$

Cacbas: De latón con dibujos grabados y armazón interior de madera.

Hoja: Muy estilizada y puntiaguda. Con dihujo típico.

Cierre: De virola giratoria.

Longitud: $22 \mathrm{~cm}$.

Epoca: Siglo xvin.

R. 2097

Cacbas: De latón con dibujos grabados.

Hoja: Con dibujos típicos hoy casi desaparecidos; hendidura longitudinal con círculos también hendidos en los extremos, pintados de rojo; leyenda ilegible.

Cicrre: De ventana, bastante grande y separado de las cachas.

Longitud: $30 \mathrm{~cm}$.

Epoca: Siglo xvill.

R. 2098 
N. ${ }^{\circ} 22$

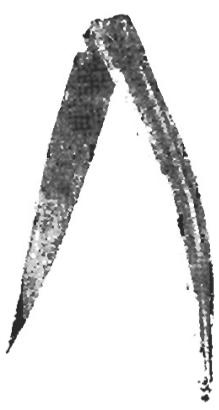

N. 23

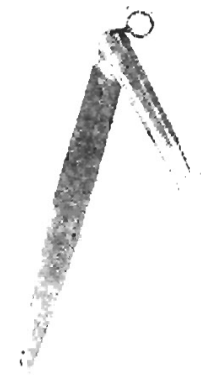

Cacbas: De latón con dibujos curvos en las partes achaflanadas y de líneas cruzadas formando rombos en el resto.

Hoja: Con refuerzo de latón en su base y dibujo hoy desaparecido.

Cierre: De ventana con cuatro dientes. Exento.

Longilad: $18 \mathrm{~cm}$.

Epoca: Siglo xvir.

$R .2099$

Cacbas: De latón con dibujos grabados formando anillos.

Hoja: Lisa al haber perdido su dibujo original; muy estilizada y puntiaguda.

Cierre: De anilla.

Longitud: $43 \mathrm{~cm}$.

Epoca: Siglo xIx.

N. ${ }^{\circ} \mathbf{2 4}$

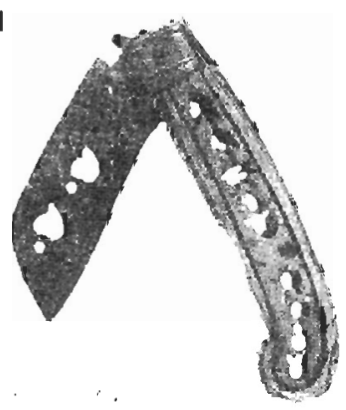

Cacbas: De asta de toro pardo claro (canela) y dibujos que taladian la cacha. La virola superior es de latón.

Hoja: Corta y ancha con dos corazones y dos círculos en su parte superior que atraviesan la hoja. Tiene unas muescas en el talón como mal trazadas c irregulares.

Cierre: De ventana.

Marca: Una P horizontal.

Longitud: $12 \mathrm{~cm}$.

Epoca: Finales del siglo xvi. $P \cdot 210$ 
N. ${ }^{\circ} 25$

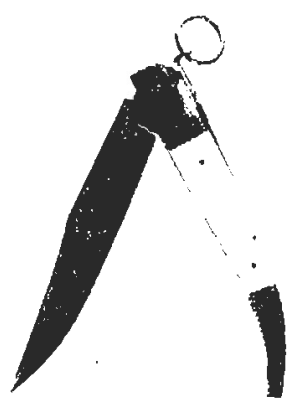

N. ${ }^{\circ} \mathbf{2 6}$

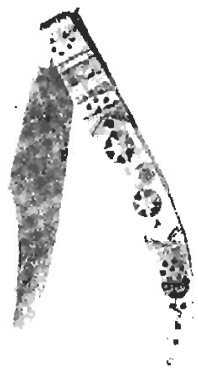

N. 27

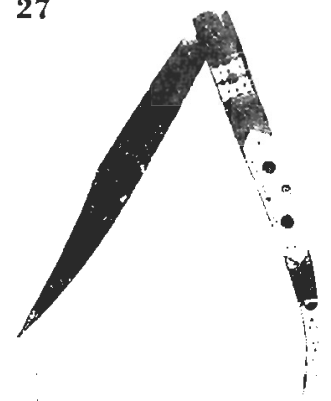

Cachas: De marfil y latón.

Hoja: Lisa.

Cierre: De anilla.

Marca: Un caballo dentro de una circunterencia.

Longilud: $13,5 \mathrm{~cm}$.

Epoca: Principios del siglo $\mathrm{xx}$.

Otros datos: Fabricada en Albacete.

R. 2102

Cachas: De latón y hueso; con dibujos que perforan la parte exterior de las cachas, formando pequeños círculos y estrellas, con el fondo recubierto de laminillas de cobre.

Hoja: Lisa.

Cierre: De varilla.

Longitud: $11,5 \mathrm{~cm}$.

Epoca: Siglo xix.

R. 2103

Cachas: De latón y matfil con dibujos a base de pequeños orificios que perforan la parte exterior de las cachas, teniendo en el fondo laminillas de cobre.

Hoja: Lisa y muy estilizada.

Cierre: De varilla.

Longilud: $19 \mathrm{~cm}$.

Epoca: Siglo xix. R. 2104 
N. ${ }^{n} 28$

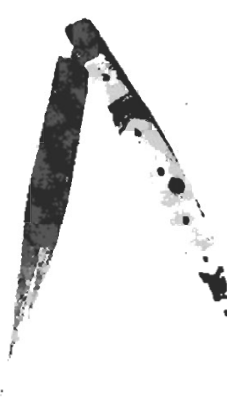

Cacbas: De hueso y latón, con pequeños clavos de este metal que sujetan aquél a la armadura.

Hoja: Muy estilizada, de tres caras; con refuerzo de latón en la base.

Cierre: De varilla.

Longitud: $18,5 \mathrm{~cm}$.

$\therefore$ Epoca: Sigloxix. R.2105

N. ${ }^{\circ} 29$

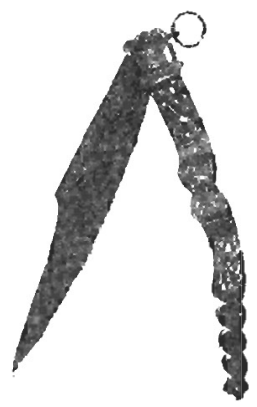

Cachas: De latón (?) y hueso teñido de color marrón oscuro con dibujos blanquecinos.

Hoja: Tiene grabada al aguafuerte una escena taurina muy bien conservada. En el otro lado pone «Viva España» enmarcado con unos adornos de hojas.

Cierre: De anilla.

Marca: Navajas de Toledo.

Longilud: $31 \mathrm{~cm}$.

Epoca: Siglo xix.

$$
R .2106 \quad(=2.20(0 \%)
$$

N. 30

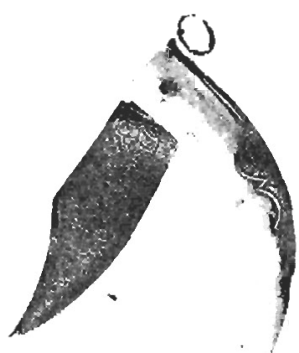

Cachas: De asta blanca de cérvido y acero. Las cachas propiamente dichas son de una sola pieza.

Hoja: Ancha con muchos dibujos grabados al aguafuerte. Tallos, hojas, perfiles humanos y de animales.

Cierre: De anilla con una ancha base cubierta de dibujos vegetales y el rostro de un guertero, todo ello al aguafuerte.

Longitud: $13,5 \mathrm{~cm}$.

Epoca: Siglo xix.

Otros dalos: Muy bien conservada. R.2107 
N. 31

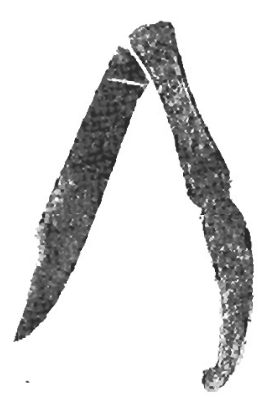

Cachas: De acero con dibujos vegetales muy logrados al aguafuerte, que cubten la totalidad de las cachas.

Hoja: Con una corona condal, «F. Mayone» y unos adornos al aguafuerte que enmarcan a aquéllos. Tiene una muesca para facilitar su apertura.

Cierre: De varilla.

Marca: Artillería, 1877, Toledo.

Longitud: $17,5 \mathrm{~cm}$.

Epoca: 1877.

Otros datos: Muy bien conservada.

R.2108

N. ${ }^{\circ} 32$

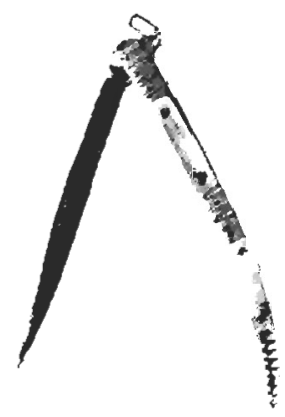

N." 33

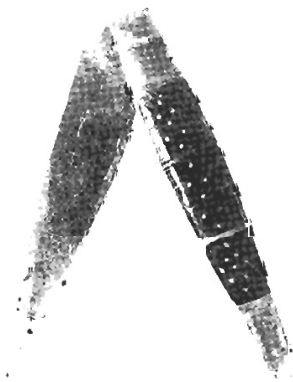

Cacbas: De nácar y metal decorado con hendiduras paralelas y perpendiculares al cje de la navaja.

Hoja: Como un estilete. Tiene una hendidura para facilitar su apertura.

Cierre: De anilla.

Longilud: $17 \mathrm{~cm}$.

Epoca: Principios del siglo xix. R. 2108

Cachas: De asta de toro negra y metal plateado; tiene dos zunchos centrales (uno desaparecido) y clavos que, formando tres rombos, adornan la parle central de las cachas.

Hoja: Muy ancha, con una muesca para facilitar su apertura.

Cierre: Sin mecanismo especial.

Marca: F R con un sol encima con rayos horizontales.

Longitud: $21,5 \mathrm{~cm}$.

Epoca: Siglo xix.

R. 2110 
N. ${ }^{\circ} 34$

N. ${ }^{\circ} 35$

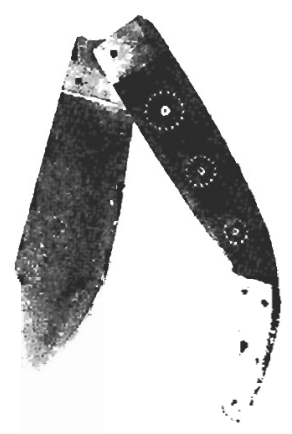

Cachas: De asta de toro negra y metal plateado; tiene tres abrazaderas del mismo metal.

Hoja: Muy ancha, puntiaguda y de pronunciadas formas curvas.

Cierre: De varilla con un saliente lateral para facilitar el cierre. Tiene cuatro dientes.

Marca: VV y un motivo alado encima.

Longitud: $19 \mathrm{~cm}$.

Epoca: Siglo xIX.

$$
\text { R. } 2111
$$

Cachas: De asta de toro negra y metal plateado con adornos grabados; en la parte central tiene tres circunferencias de clavos plateados con el centro de asta blanca y negra.

Hoia: Muy ancha con dibujos vegetales grabados. Por la otra cara el dibujo es mucho más sencillo. Tiene un refuerzo metálico con adornos en la base de la hoja.

Cierre: Sin mecanismo especial.

Marca: Fábrica de Fernández. Año 1906. Montijo.

Longitud: $21 \mathrm{~cm}$.

Epoca: Principios del siglo xx. R. $2 / 12$

N. ${ }^{\circ} 36$

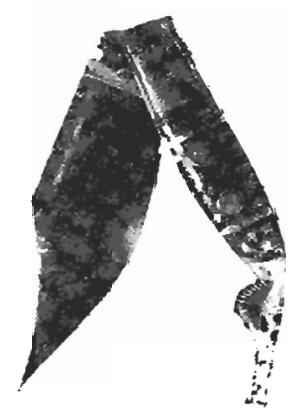

Cachas: De asta de toro negra y metal plateado con bellos dibujos grabados y molduras; tiene dos abrazaderas grabadas, dos monedas de Isabel II de 1853 y 1862 y clavos.

Hoja: Muy ancha y curva; tiene una hendidura ancha y cinco muescas adornadas en el recazo. Parte de la base de la hoja tiene un refuerzo con adornos.

Cierre: De lengüeta con tres dientes.

Marca: F horizontal.

Longitud: $23 \mathrm{~cm}$.

Epoca: Siglo XIX.

Otros datos: Muy bien conservada.
$R .2113$ 
Y. 37

N. ${ }^{\circ} 38$

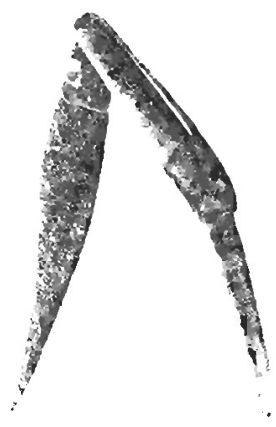

N." 39

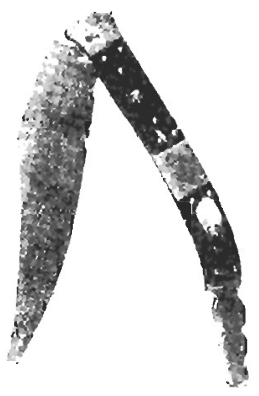

Cachas: De madera labrada profundamente a base de motivos vegetales y florales, y latón, con dibujos florales grabados y calados en la parte central de las cachas, que dejan al descubierto laminillas de cobre.

Hoia: Muy larga y estilizada. Tiene sencillos dibujos florales y vegetales. En el lado opuesto los dibujos son más escasos.

Cierre: De anilla con tres dientes.

Marca: Un sol.

Longitud: $54 \mathrm{~cm}$.

Epoca: Siglo xIX.

Otros datos: Abierta mide $97 \mathrm{~cm}$.

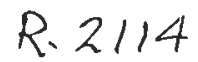

Cachas: De latón muy labrado, a base de dibujos que giran alrededor de un centro en la parte superior, y rayas, en su mayoría paralelas, en el resto de las cachas. El latón recubre prácticamente la totalidad de las guardas. El interior es de asta de toro marrón oscuro.

Hoja: Muy deteriorada, tenía un dibujo hoy casi completamente desaparecido con incrustaciones de pequeños círculos de latón y reforzada la base de la hoja.

Cierre: De ventana, muy grande, forrado de latón, muy decorado y con scis dientes.

Longitud: $30 \mathrm{~cm}$.

Epoca: Siglo xix.

Otros datos: En el refuerzo de la base de la hoja parece que pone 1882 y una inicial por el lado opuesto.

$R .211$

Cachas: De asta de toro negra y blanca con remaches de latón, dos de ellos en forma de flor, y latón. El extremo inferior, que es posterior, forma como tres círculos en disminución.

Hoja: Ancha.

Cierre: De varilla.

Marca: Villega Barbastro.

Longiul: $23 \mathrm{~cm}$.

Epoca: Siglo xIx.

Otros datos: En la línea de la navaja catalana (Pagć, pág. 1.286 bis).

\section{1). 211}




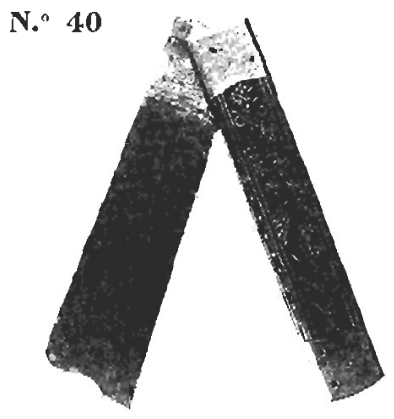

Cacbas: De madera, con incrustaciones vegetales y de frutos, y larón, con adornos grabados. En el lado opuesto, incrustado también en latón, pone: «Santa Marta 25 de Junio de 1908 Cándido».

Hoja: Muy ancha, algo más al final que en su base. El extremo de la hoja es romo y la base tiene un refuerzo de latón grabado, en uno de cuyos lados pone 1908.

Cierre: Sin mecanismo especial.

Longilud: $22 \mathrm{~cm}$.

Epoca: Principios del siglo xix.

Otros datos: El extremo inferior de una cacha tiene grabadas las iniciales BC.
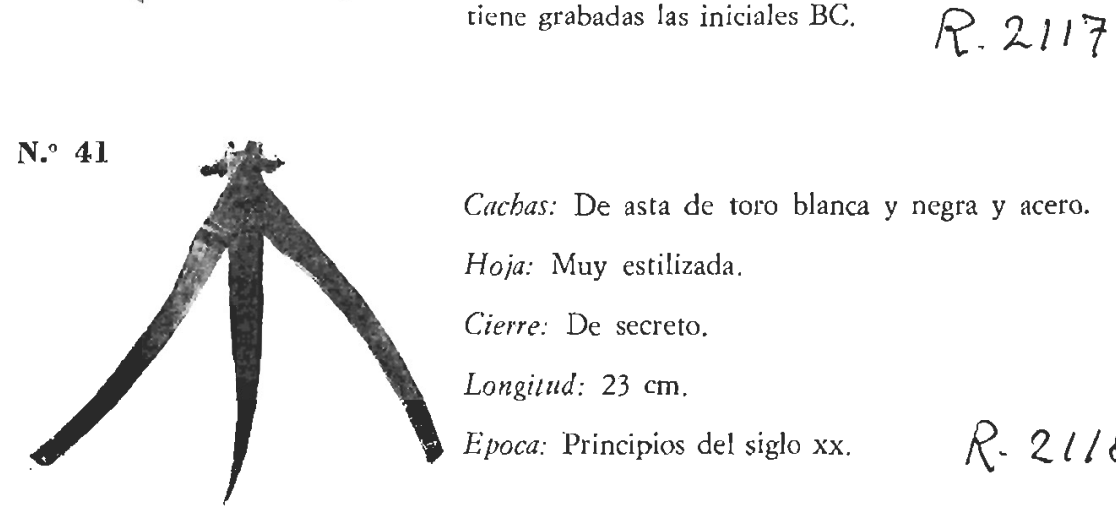

Cachas: De asta de toro blanca y negra y acero.

Hoja: Muy estilizada.

Cierre: De secreto.

Langitud: $23 \mathrm{~cm}$.

Epoca: Principios del siglo xx.

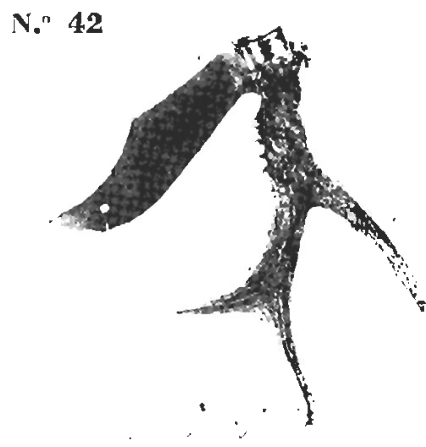

Cachas: De asta de corzo o ciervo color castaño claro, con tres puntas.

Hoja: Lisa, de pronunciadas curvas, con dos muescas para facilitar su apertura.

Cierre: De virola girable.

Longitud: $23,5 \mathrm{~cm}$.

Epoca: Finales del siglo $\mathrm{xIx} /$ Principios del siglo $\mathrm{xx}$.

$$
\text { R. } 2119
$$


N. 43

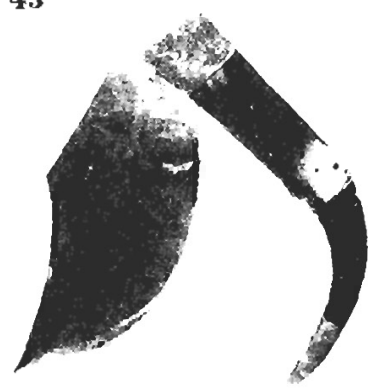

Cachas: De asta de toro blanca y negra y latón.

Hoja: Anchísima y de curvas muy pronunciadas.

Cierre: De varilla, muy robusta en el extremo.

Marca: Sixto, escrito por ambas caras.

Longirued: $27,5 \mathrm{~cm}$.

Epoca: Finales del siglo xix. R. 2120

N. ${ }^{\circ} 44$

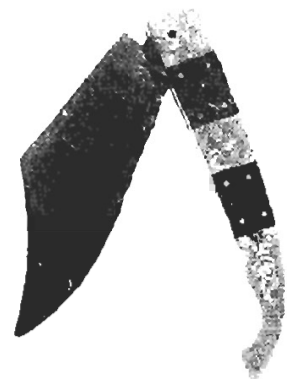

N." 45

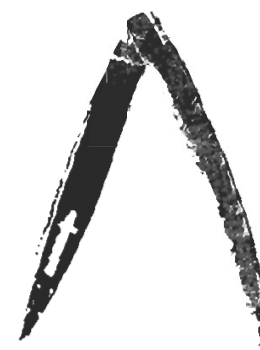

Cacbas: De carey muy oscuro y metal plateado con flores con las iniciales I y A muy bien grabadas.

Hoja: Muy ancha y con una muesca para facilitar su apertura.

Cierre: De varilla.

Marca: Una M horizontal.

Longitud: $16 \mathrm{~cm}$.

Epoca: Siglo $\mathrm{xIx}$.

$R .2121$

Cacbas: De acero moldurado en sus esquinas.

Hoja: Con un refuerzo de latón en su base; cuatro agujeros y una cruz toscamente realizada perforan la hoja.

Cierre: De ventana.

Longitud: $23 \mathrm{~cm}$.

Epoca: Siglo xix. 
N. ${ }^{\circ} 46$

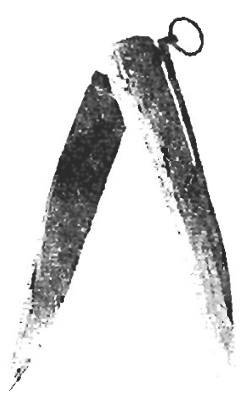

N.0 4.7

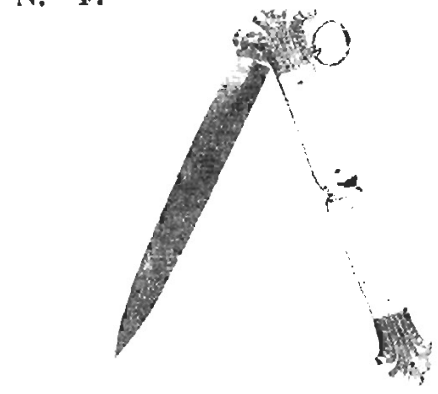

N. ${ }^{a} 48$

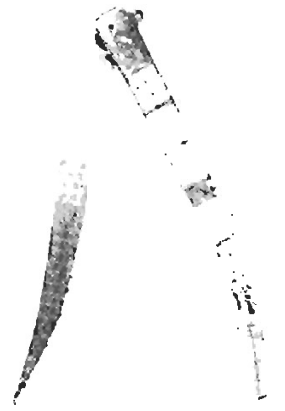

Cacbas: De asta de cérvido blanca de una sola pieza.

Hoja: Lisa, con muesca para facilitar su apertura.

Cierre: De anilla.

Marca: R. C. dentro de un óvalo.

Longitud: $22,5 \mathrm{~cm}$.

Epoca: Siglo xix.

R. 2123

Cachas: De hueso amarfilado y metal platcado que forma en sus extremos un dibujo que recuerda las ramas de una palmera.

Hoja: De duble filo y dos caras por cada lado.

Tiene una muesca para facilitar su apertura.

Cierre: De anilla.

Longitud: $22 \mathrm{~cm}$.

Epoca: Siglo xix.

Otros datos: Se trata de un puñal plegable.

\section{$R \cdot 2124$}

Cachas: De nácar, con aspas grabadas y metal plateado.

Hoja: Muy estilizada.

Cierre: De anilla con cuatro dientes.

Longitud: $24 \mathrm{~cm}$.

Epoca: Siglo $\mathrm{x} x$. 


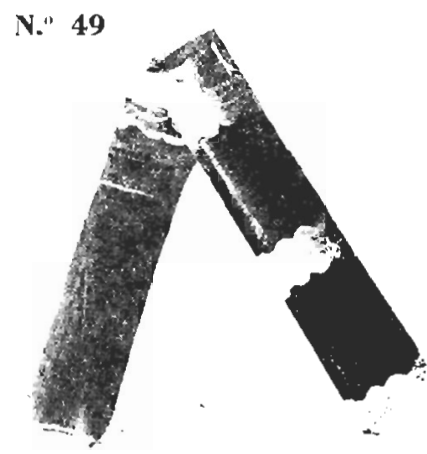

Cachas: De concha negto-verdosa y metal plateado con adornos grabados.

Hoja: De punta roma y formas paralelas. Tiene un refuerzo en la base.

Cicrre: De varilla con un saliente lateral para facilitar el cierre.

Longitud: $9,5 \mathrm{~cm}$.

Epoca: Principios del siglo xx.

Otros datos: Procede de Cortegana (Huelva). R. 212

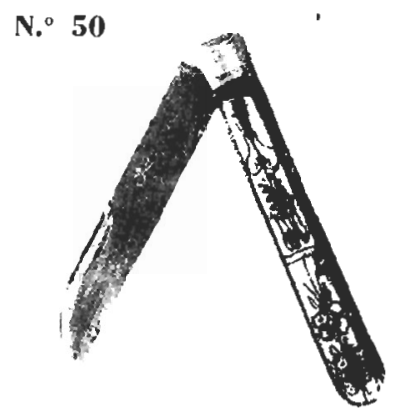

Cacbas: De hueso, con dibujos florales pintados en color castaño.

Hoja: Recta, con muesca para facilitar su apertura.

Cierre: De varilla.

Marca: 71 y una corona real, ambos en posición horizontal. Garantizado.

Longitud: $8,5 \mathrm{~cm}$.

Epoca: Finales del siglo xix.

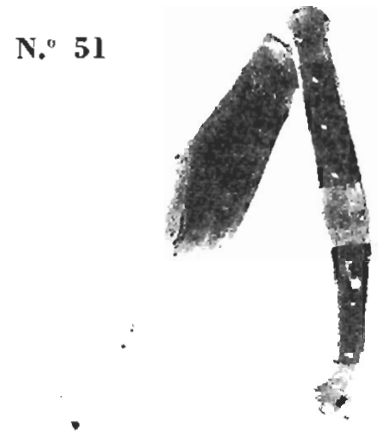

Cacbas: De asta de toro marrón y acero.

Hoja: Muy ancha, de pronunciadas curvas y con muesca para facilitar su apertura.

Cierre: De varilla.

Marca: R horizontal.

Longitud: $19,5 \mathrm{~cm}$.

Epoca: Siglo xix.

R. 2128 
N. 52

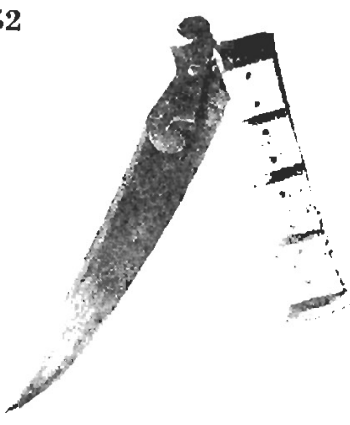

Cachas: De nácar y latón, con tres abrazaderas y clavos del misno metal.

Hoja: Lisa.

Cicre: De varilla, con deslizamiento de la cruz.

Marca: Fortún, Zaragoza.

Longilud: $21 \mathrm{~cm}$.

Epoca: Siglo $\mathrm{x} \perp \mathrm{x}$.

Otros dalos: Se trata de un cuchillo plegable. Abierto mide $32 \mathrm{~cm}$.

R 2129
N. ${ }^{0} 53$

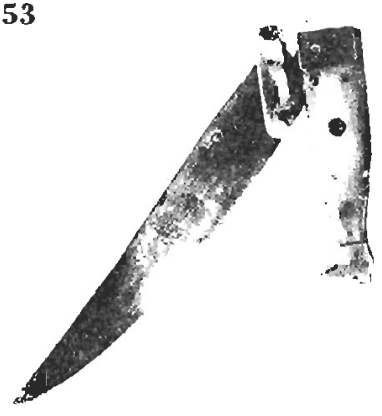

Cachas: De asta de toro blanca, con dos círculos centrales de asta de toro marrón, y latón. Tiene la forma de una bota de mujer.

Hoja: Lisa.

Cierre: De varilla con deslizamiento de la cruz.

Marca: Una llave horizontal.

Longilud: $23 \mathrm{~cm}$.

Epoca: Siglo xix.

Otros datos: Se trata de un cuchillo plegable. Abierto mide $32,5 \mathrm{~cm}$.

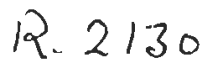

N. ${ }^{n 4}$

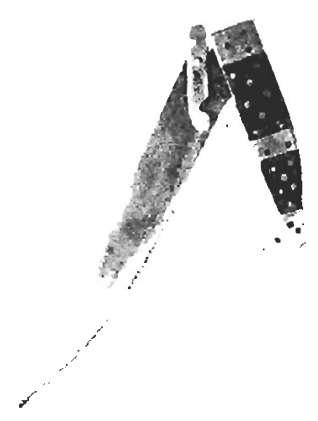

Cachas: De asta de toro negra con clavos de latón, y latón con clavos de hierro.

Hoja: Lisa.

Cierre: De ventana, con deslizamiento de la cruz.

Longilud: $22 \mathrm{~cm}$.

Epoca: Siglo xix.

Otros datos: Se trata de un cuchillo plegable. Abierro mide $31 \mathrm{~cm}$. 
N. ${ }^{\circ} 55$

N. ${ }^{\circ} 56$

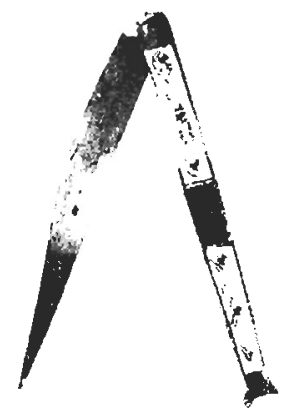

Cachas: De hueso, pintado de color marrón con dibujos, y latón.

Hoja: Ancha.

Cierre: De anilla,

Marca: Bechona y con punzón que recuerda en parte a un compás.

Longilud: $24 \mathrm{~cm}$.

Epoca: Siglo xix.

Olros dalos: De fabricación francesa.

Cachas: De hueso, con arandelas de latón en los clavos de sujeción y dibujos florales pintados en color marón; latón; y un orificio en el extremo inferior.

Hoja: Lisa y puntiaguda.

Cierre: De varilla.

Marca: Riberon y un alfanje encima.

Longilud: $23 \mathrm{~cm}$.

Epoca: Finales del siglo xvirr/Principios del siglo XIX.

Otros datos: De fabricación francesa.
N. ${ }^{\circ} 57$

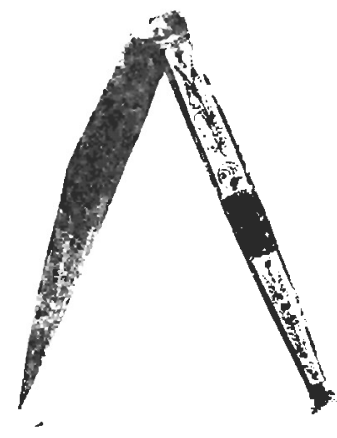

Cuchas: De hueso, con arandclas de latón en los clavos de sujeción y dibujos florales pintados en color marrón; latón; y un orificio en el extremo inferior.

Hoja: Lisa y puntiaguda.

Cierre: De varilla.

Marca: Riberon y un alfanje encima.

Longilud: $26 \mathrm{~cm}$.

Epoca: Finales del siglo xvır/Principios del siglo XIX.

Otros datos: De fabricación francesa.

R. 2134

$$
(=R \cdot 2 C(R)
$$


N. ${ }^{\circ} \mathbf{5 8}$

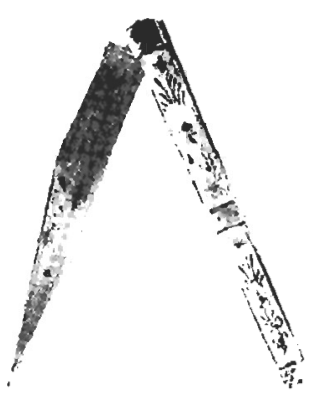

N. 59

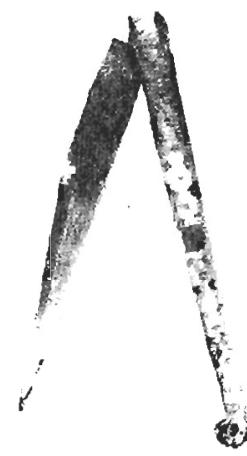

Cachas: De hueso, con arandelas de latón en los clavos de sujeción y dibujos florales pintados en color marrón; latón; y un orificio en el extremo inferior, que termina en forma redonda.

Hoja: Lisa y puntiaguda.

Cierre: De varilla.

Marca: Riberon y un alfanje encima.

Longitud: $22 \mathrm{im}$.

Epoca: Finales del siglo xvm/Principios del siglo Xix.

Otros dalos: De fabricación funcesa. . R. $2 / 35$

Cachas: De asta blanca-pardo-rosácea, con muchos clavos y latón, que en su parte inferior tiene forma redonda.

Hoja: Puntiaguda y rayada formando pequeños rombos.

Cierre: De varilla.

Marca: Lacassis y debajo A Oloron.

Longilud: $26 \mathrm{~cm}$.

Epoca: Finales del siglo xvin/Principios del siglo XIX.

Otros dalos: De fabricación francesa.

N. 60

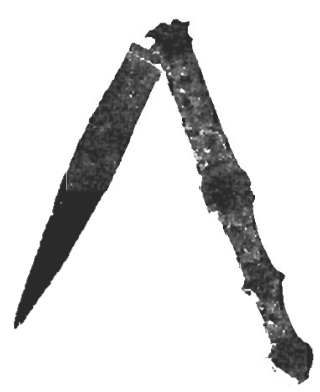

Cachas: De asta amarillo-rosácea muy deteriorada, con clavos de latón de dos tamaños y latón muy moldurado.

Hoja: Lisa y fusiforme.

Marca: Pique y debajo A Oloron.

Longilud: $20 \mathrm{~cm}$.

Epoca: Principios del siglo xIx.

Otros datos: De fabricación francesa.

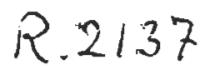




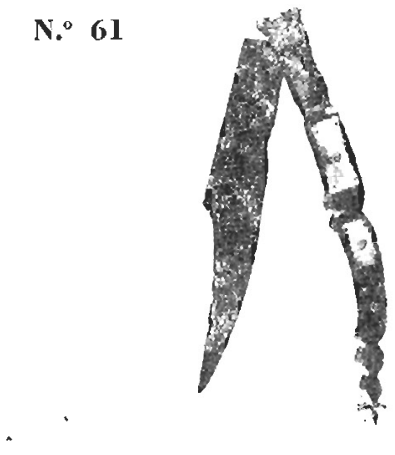

N. ${ }^{62}$

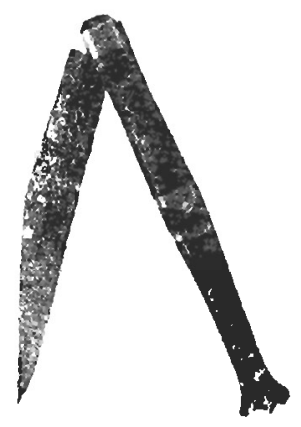

Cachas: De asta de toro negra y blanco-rosácea, con clavos centrales en forma de flor; latón, que termina en su extremo inferior en un óvalo, un lombo y una especie de cruz.

Hoja: Lisa, estrechándose mucho en la parte superior.

Cierre: De varilla.

Marca: Haudeville y debajo A Oloron.

Longitud: $32 \mathrm{~cm}$.

Epoca: Principios del siglo xix.

Otros datos: De fabricación francesa. $R .2138$

$$
(=R \cdot 2 i(\cdot)
$$

Cachas: De carey, con elaboradas incrustaciones metálicas y metal plateado. En el extremo inferior tiene un orificio por el que pasa una anilla. Hoja: Con dibujos al aguatuerte casi inapreciables y de forma recta po: el lado del filo. Por el lado opuesto se pucde lecr en letra cursiva: Bragulat, probablemente grabado por su propietario. Tiene una muesca para facilitar su apertura.

Cierre: De varilla.

Marca: Dubost; debajo, St Joants, y al lado izquierdo, una cuerna.

Longilud: $19,5 \mathrm{~cm}$.

Epoca: Principios del siglo XIX.

Orros datos: De fabricación francesa.

R. 2139

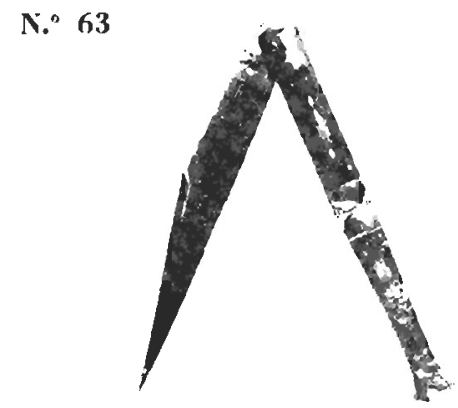

Cachas: De carcy, asta de toro negra, con pequeños óvalos de nácar y la figura de un turco de metal incrustados; metal plateado y un orificio en la parte inferior.

Hoja: Lisa, con una muesca para facilitar su apertura, y recta por el lado del filo.

Cierre: De varilla.

Marca: Girodias y un velón encendido en posición horizontal.

Longilud: $21 \mathrm{~cm}$.

Epoca: Principios del siglo xix.

Otros datos: De fabricación francesa.

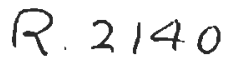




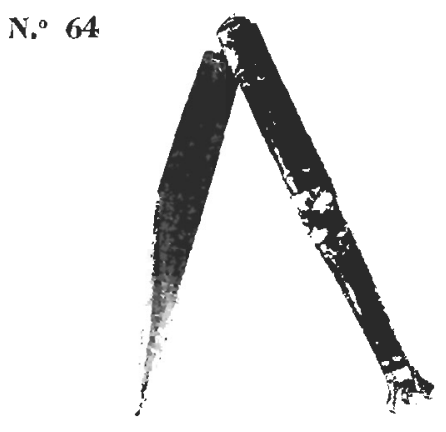

Cachas: De carey y asta de toro negra, con un pequeño adorno metálico incrustado; metal plateado con un orificio en el extremo inferior atravesado por una anilla.

Hoja: Con dibujos vegetalcs al aguafuerte y la leyenda «Viva Figueras».

Cierre: De varilla.

Marca: Girodias y un velón horizontal.

Longitud: $19 \mathrm{~cm}$,

Epoca: Principios del siglo xIx.

Otros datos: De fabricación francesa.
N." 65

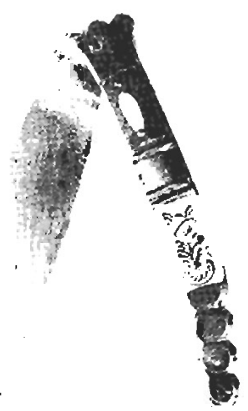

N. ${ }^{\circ} 66$

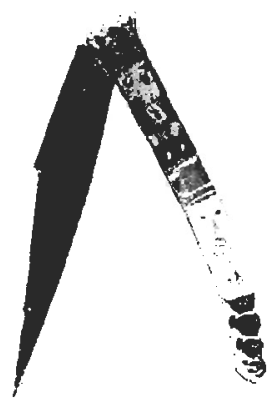

Cacbas: De carey, con un adorno ovalado incrustado; hueso blanco, con motivo vegetal pintado; y latón, terminando en tres círculos de mayor a menor tamaño, con un orificio el último de ellos. Hoja: Lisa y ancha, con muesca para facilitar su apertura.

Cierre: De varilla.

Longitud: $14,5 \mathrm{~cm}$.

Epoca: Finales del siglo xvin/Principios del siglo XIX.

Otros datos: De fabricación francesa. $R .2442$

Cachas: De carey, con adorno plateado incrustado; hueso blanco, con dibujo floral; y latón, terminando en tres círculos de mayor a menor tamaño, con un orificio en el último de ellos.

Hoia: Con dibujos vegetales al aguafuerte casi desaparecidos.

Cierre: De varilla.

Marca: Beauvoir y un diapasón (?) horizontal.

Longitud: $21 \mathrm{~cm}$.

Epoca: Finales del siglo xvin/Principios del siglo XIX.

Orros datos: De tabricación francesa. R. 2143 
N." 67

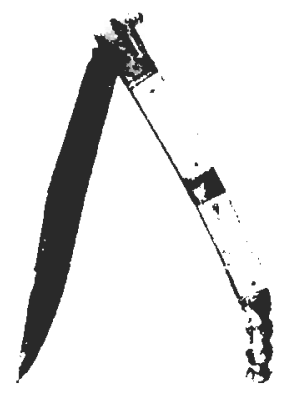

Cachas: De hueso, con dibujos florales, y acero, terminando en tres esferas achatadas de mayor a menor tamaño.

Hoja: Lisa y de líneas casi paralelas.

Cierre: De anilla.

Longilud: $23 \mathrm{~cm}$.

Epoca: Principios del siglo xIx.

Otros dalos: De fabricación francesa, probablemente de Châtellerault.
N. 68

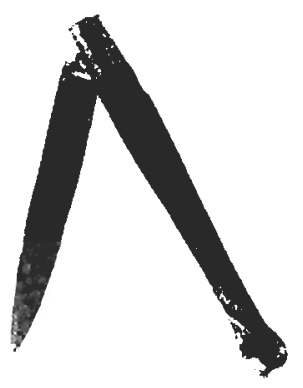

N. 69

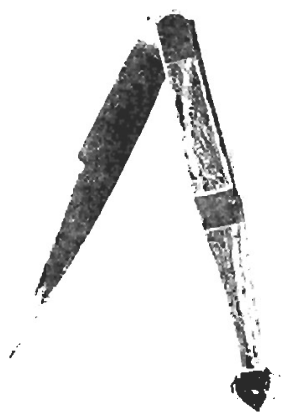

Cachas: De madera oscura y vetada, en forma más o menos cilíndrica, terminando en una bola. De una sola pieza.

Hoja: Lisa, con una mucsca para facilitar su apertura.

Cierre: De virola giratoria, con la marca Morel Couzon en la parte posterior.

Marca: Morel Couzon.

Longitud: $20,5 \mathrm{~cm}$.

Epoca: Finales del siglo $\mathrm{x} I x /$ Principios del siglo $\mathrm{xx}$.

Otros datos: De fabricación francesa.

R. 2145

Cacbas: De asta de ciervo marrón y latón. Tiene en el extremo inferior un orificio con una arandela.

Hoja: Lisa, fusiforme y puntiaguda.

Cierre: De varilla.

Marca: ...jque y como una bota horizontal.

Longitud: $23 \mathrm{~cm}$.

Epoca: Finales del siglo xIx.

Otros datos: De fabricación francesa.

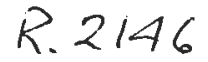

89 
N. ${ }^{\circ} 70$

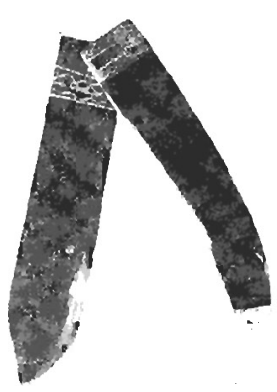

N. ${ }^{\circ} 71$

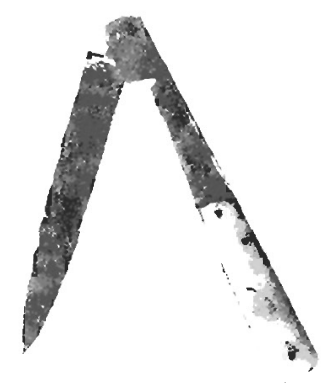

Cacbas: De asta de toro negra y metal plateado, con adornos grabados.

Hoja: Muy ancha y de líneas casi paralelas; tiene un refuerzo metálico con adornos en la basc.

Cierre: Sin mecanismo especial.

Marca: Ed. Mongin, París, y una balanza al lado.

Longilud: $21 \mathrm{~cm}$.

Epoca: Siglo XIX.

Otros dalos: De fabricación francesa. $R .2147$

Cacbas: De hueso, con dibujos florales sencillos, y acero.

Hoja: Lisa, con siete muescas en el recazo por cada lado y otra más en la cara para facilitar la apertura.

Cierre: De varilla.

Marca: Vauzy, con un torreón con cruz.

Longilud: $19 \mathrm{~cm}$.

Epoca: Siglo XIX.

Otros dalos: De fabricación francesa (corsa). Se trata de un cuchillo plegable.

R. 2148

N. 72

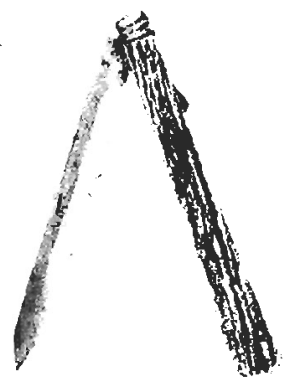

Cacbas: De asta de cérvido, con una placa metáJica alargada.

Hoja: De dos caras cada lado, con una muesca para facilitar su apertura y de líneas completamente paralelas.

Cierre: De varilla, con seguro de presión en la parte superior y posterior.

Marca: ... \& W Hanocer (?) \& Sons, Sheffield, en el talón.

Longilud: $23 \mathrm{~cm}$.

Epoca: Finales del siglo xix.

Otros dalos: De fabricación inglesa.

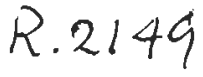


N. ${ }^{\circ} 73$

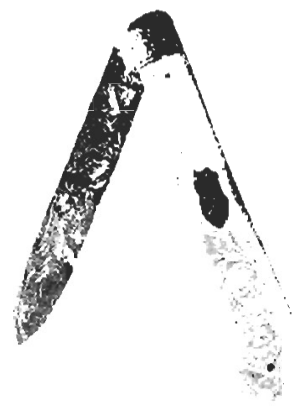

Cacbas: De nácar, con dibujos vegetales y florales grabados y las iniciales MAS en un pequeño escudo de plata, y plata. Por el otro lado el dibujo es mucho más sencillo.

Hoja: De plata muy grabada con dibujos de frutos. Por el otro lado está lisa.

Cierre: De varilla.

Marca: Una corona, con león, una a y H. A.

Longitud: $9 \mathrm{~cm}$.

Epoca: Siglo xix.

Otros datos: De fabricación inglesa.

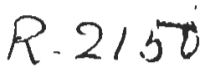

N." 74

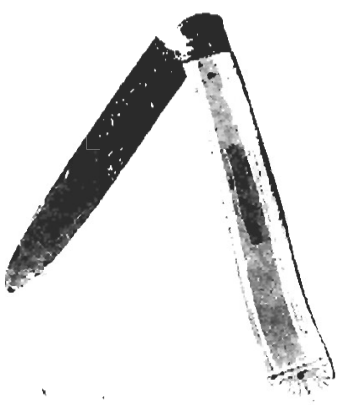

Cachas: De nácar, con dibujos sencillos y una plaquita de plata incrustada, y plata.

Hojo: De plata, lisa, con una muesca para facilitar su apertura y sin punta, quizá desgastada.

Cierre: De varilla.

Marca: Un león, un perfil de mujer, una $\mathrm{C}$, un ancla y $\mathrm{G} U$.

Longitud: $9 \mathrm{~cm}$.

Epoca: Siglo xix.

Otros datos: De fabricación inglesa. $R \cdot 2 / 5 \%$

N. 75

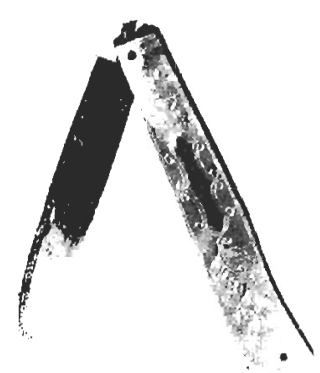

Cacbas: De nácar, con una plaquita de plata grabada e incrustada y unos dibujos vegetales grabados.

Hoja: De plata, con una orla grabada en la parte que no tiene corte.

Cierre: De varilla.

Marca: Un león, un perfil de mujer, dos punzoncs que no se leen y F. C.

Longitud: $8 \mathrm{~cm}$.

Epoca: Siglo XIX.

Otros datos: De fabricación inglesa. 
N. 76

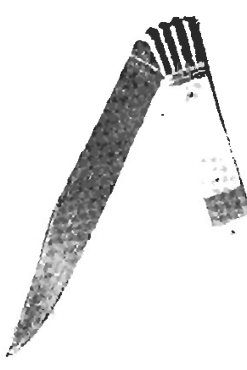

Cachas: De nácar y metal plateado ligeramente moldurado.

Hoja: Lisa, con una muesca para facilitar su apertura.

Cierre: De varilla.

Marca: F. Herberz, Solingen, en el talón.

Longitud: $17 \mathrm{~cm}$.

Epoca: Siglo xix.

Otros datos: De fabricación alemana. $R .2153$

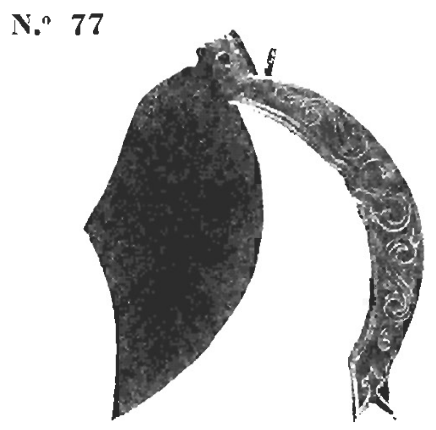

N. ${ }^{\circ} 78$

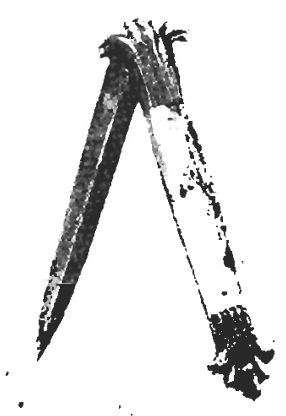

Cachas: De metal plateado; en forma de $\mathrm{C}$; con sencillos dibujos grabados y con una $\mathrm{S}$ y una $\mathrm{F}$ en las partes centrales de cada cara.

Hoja: Lisa, de muy pronunciadas curvas.

Cierre: De ventana, con anilla y siete dientes.

Longitud: $29,5 \mathrm{~cm}$.

Epoca: Siglo xix.

Orros datos: Posiblemente de fabricación chilena. Pesa 1,3 kg.

R. 2154

Cachas: De nácar acanalado y metal plateado que forma en sus extremos un dibujo que recuerda las ramas de la palmera.

Hoja: De dos caras por cada lado. Tiene una pequeña muesca para facilitar su apcrtura.

Cierre: De resorte.

Longitud: $16 \mathrm{~cm}$.

Epoca: Siglo Xix.

Orros datos: Se trata de un puñal plegable.

$$
\text { R. } 2.155
$$




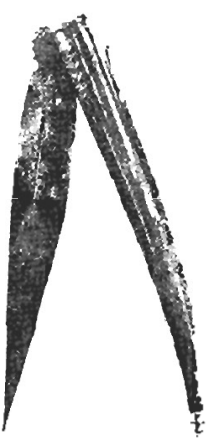

Cacbas: De latón, con dibujos grabados recrilíneos en los extremos y de puntos en el centro.

Hoja: Con dibujos típicos; hendidura longitudinal con una estrella y otro adorno en forma de cruz en los extremos, pintados de rojo; leyenda: «Soy... dueño». «Si... víbora re pica, no acudas...», entre las dos caras.

Cierre: De ventana, con cinco dienres; exento.

Longitud: $25 \mathrm{~cm}$.

Epoca: Siglo xvirr.

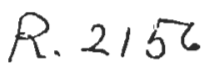

N." 80

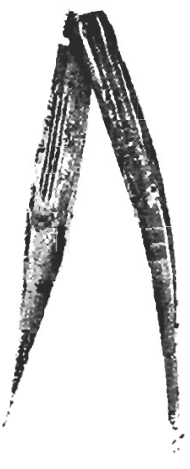

Cachas: De latón con dibujos grabados. De línea muy estilizada.

Hoja: Con dibujos grabados en ambas caras; tiene rres hendiduras longitudinales pintadas en rojo; leyenda: "Soy defensa de uso valie... y viva»; muy puntiaguda.

Cierre: De ventana, con seis dientes; exento.

Longilud: $25,5 \mathrm{~cm}$.

Epoca: Siglo xvir.

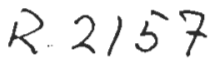

N." 81

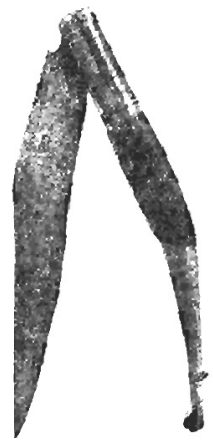

Cacbas: De latón, con dibujos grabados; la parte supetior es cilíndrica; la central, de madera color castaño-negro, igual que todo el interior; en el extremo inferior tiene una pequeña asa tambićn de latón para su sujeción.

Hoja: Lisa.

Cierre: De virola giratoria.

Marca: Una G horizontal con una corona encima.

Longilud: $23 \mathrm{~cm}$.

Epoca: Siglo xviri.

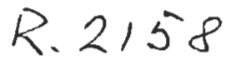


N. 82

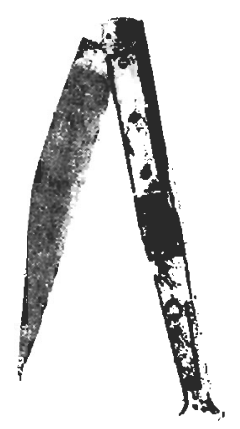

N. ${ }^{\circ} 83$

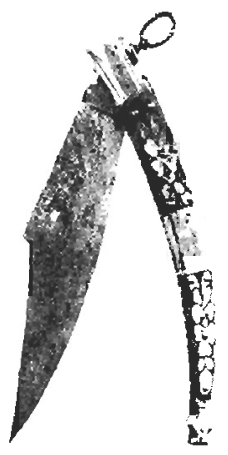

Cacbas: De hueso, con arandelas de latón en los clavos de sujeción y dibujos vegetales pintados en color marrón; latón, y un orifico en el extremo inferior.

Hoja: Con dibujos vegretales al aguafuerte; muy puntiaguda.

Cierre: De varilla.

Marca: Riberon y un alfanje encima.

Longitud: $20 \mathrm{~cm}$.

Epoca: Finales del siglo xvirl/Principios del siglo xix.

Otros datos: De fabricación francesa. $R+2159$

Cachas: De hueso, pintadas con dibujos de color marrón, y latón.

Hoja: Ancha, con restos de dibujos al aguafuerte.

Cierre: De anilla.

Longilud: $24 \mathrm{~cm}$.

Epoca: Siglo xIx.

Otros datos: De fabricación francesa.

R. 2160 


\section{INDICE DE ILUSTRACIONES}

1. «El Desquite», de José Bermejo Sobera ................. 5

2. La zillima escena de «ManoLo», estampa anónima ..... 7

3. «El descanso en la marcha», de Juan Benlliure

4. «Cucbillero español» ........

5. Navaja

6. «La Navaja», de Gustavo Doré

7. «Ll enano de la venta»...

8. Navaja de secrelo ............

9. Navaja de Toledo

10. «Vendedor de cuchillos chinos)

11. Mapa de España en el que se indican los lugares en que en algain momenlo se fabricaron navajas

5

7




\section{N D I C E}

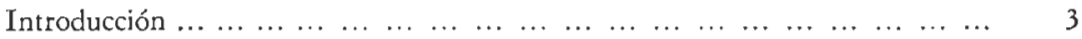

$\begin{array}{llllllllllllllll}\text { Rehabilitación de la navaja } & \ldots & \ldots & \ldots & \ldots & \ldots & \ldots & \ldots & \ldots & \ldots & \ldots & \ldots & \ldots & \ldots & \ldots & \end{array}$

$\begin{array}{lllllllllllllllllllll}\text { Definición } & \ldots & \ldots & \ldots & \ldots & \ldots & \ldots & \ldots & \ldots & \ldots & \ldots & \ldots & \ldots & \ldots & \ldots & \ldots & \ldots & \ldots & \ldots & \ldots & 11\end{array}$

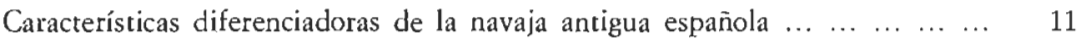

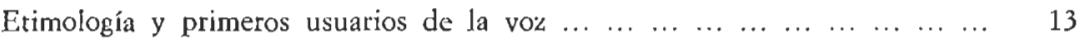

$\begin{array}{llllllllllllllllllll}\text { Otras denominaciones } & \ldots & \ldots & \ldots & \ldots & \ldots & \ldots & \ldots & \ldots & \ldots & \ldots & \ldots & \ldots & \ldots & \ldots & \ldots & \ldots & 14\end{array}$

$\begin{array}{llllllllllllllllllll}\text { Materiales empleados } & \ldots & \ldots & \ldots & \ldots & \ldots & \ldots & \ldots & \ldots & \ldots & \ldots & \ldots & \ldots & \ldots & \ldots & \ldots & \ldots & 14\end{array}$

$\begin{array}{llllllllllllllllllllllll}\text { Formas } & \ldots & \ldots & \ldots & \ldots & \ldots & \ldots & \ldots & \ldots & \ldots & \ldots & \ldots & \ldots & \ldots & \ldots & \ldots & \ldots & \ldots & \ldots & \ldots & \ldots & 15\end{array}$

$\begin{array}{llllllllllllllllllll}\text { Decoración } & \ldots & \ldots & \ldots & \ldots & \ldots & \ldots & \ldots & \ldots & \ldots & \ldots & \ldots & \ldots & \ldots & \ldots & \ldots & \ldots & \ldots & \ldots & \ldots\end{array}$

$\begin{array}{llllllllllllllllll}\text { Leyendas } \operatorname{grabadas} & \ldots & \ldots & \ldots & \ldots & \ldots & \ldots & \ldots & \ldots & \ldots & \ldots & \ldots & \ldots & \ldots & \ldots & \ldots & \ldots & \ldots\end{array}$

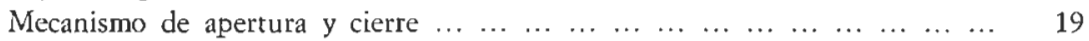

$\begin{array}{lllllllllllllllllllllllll}U \operatorname{Usos} & \ldots & \ldots & \ldots & \ldots & \ldots & \ldots & \ldots & \ldots & \ldots & \ldots & \ldots & \ldots & \ldots & \ldots & \ldots & \ldots & \ldots & \ldots & \ldots & \ldots & \ldots & 22\end{array}$

$\begin{array}{lllllllllllllllll}\text { Geografía de la navaja } & \ldots & \ldots & \ldots & \ldots & \ldots & \ldots & \ldots & \ldots & \ldots & \ldots & \ldots & \ldots & \ldots & \ldots & \ldots & \ldots\end{array}$

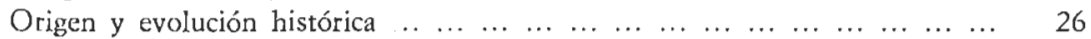

$\begin{array}{llllllllllllllllll}\text { Sociología de la navaja } & \ldots & \ldots & \ldots & \ldots & \ldots & \ldots & \ldots & \ldots & \ldots & \ldots & \ldots & \ldots & \ldots & \ldots & \ldots & & 38\end{array}$

$\begin{array}{llllllllllllllllllll}\text { Su carácter civil } & \ldots & \ldots & \ldots & \ldots & \ldots & \ldots & \ldots & \ldots & \ldots & \ldots & \ldots & \ldots & \ldots & \ldots & \ldots & \ldots & \ldots & \ldots & 41\end{array}$

$\begin{array}{llllllllllllllllllllll}\text { Legislación } & \ldots & \ldots & \ldots & \ldots & \ldots & \ldots & \ldots & \ldots & \ldots & \ldots & \ldots & \ldots & \ldots & \ldots & \ldots & \ldots & \ldots & \ldots & \ldots & 41\end{array}$

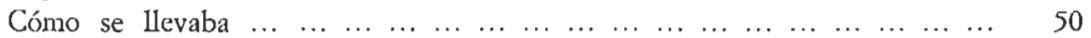

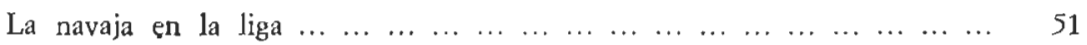

$\begin{array}{lllllllllllllllllllllll}\text { Marcas } & \ldots & \ldots & \ldots & \ldots & \ldots & \ldots & \ldots & \ldots & \ldots & \ldots & \ldots & \ldots & \ldots & \ldots & \ldots & \ldots & \ldots & \ldots & \ldots & \ldots & & 51\end{array}$

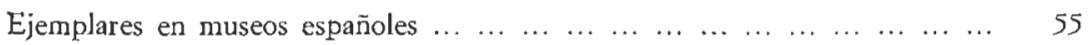

$\begin{array}{llllllllllllllllll}\text { Escase } z \text { de ejemplares } & \ldots & \ldots & \ldots & \ldots & \ldots & \ldots & \ldots & \ldots & \ldots & \ldots & \ldots & \ldots & \ldots & \ldots & \ldots & \ldots & 60\end{array}$

$\begin{array}{lllllllllllllll}\text { Textos diterarios sobre la navaja } & \ldots & \ldots & \ldots & \ldots & \ldots & \ldots & \ldots & \ldots & \ldots & \ldots & \ldots & \ldots & \ldots & 62\end{array}$

$\begin{array}{llllllllllllllllllllll}\text { Catálogo } & \ldots & \ldots & \ldots & \ldots & \ldots & \ldots & \ldots & \ldots & \ldots & \ldots & \ldots & \ldots & \ldots & \ldots & \ldots & \ldots & \ldots & \ldots & \ldots & \ldots & 65\end{array}$

$\begin{array}{llllllllllllllllll}\text { Indice de ilustraciones } & \ldots & \ldots & \ldots & \ldots & \ldots & \ldots & \ldots & \ldots & \ldots & \ldots & \ldots & \ldots & \ldots & \ldots & \ldots & \ldots & 95\end{array}$ 


\section{S U M M A R Y}

The present work comprises an investigation of the Spanish navajas, their history in general and an illustrated catalogue of the author's collection. This collection, commenced many years ago, forms the basis of the investigation, supported by examinations of navajas from several museums, representations in art as well as literary documentation from archives and books. It doesn't pretend to give an exhaustive and complete scientific treatment of a weapon which never before has attracted the attention of arms' students and about which very little, indeed, has been written. The purpose has been to throw some light upon the history and use of a characteristic Spanish category of weapons and of an industry which is deeply rooted on the Iberian Peninsula. The part of the article treating the navajas in general is followed by some plates with representations of marks and stamps from the author's collection.

During centuries the navajas formed an integral part of Spanish life. Everybody, rich or poor, countryman or citizen, old or young, had a navaja of his own, which he wore with pride. In certain parts of the Peninsula, not least in the province of Almería, a characteristic practice ruled among the miners. When a son completed his 18 th year he received from his father the «faca», a long and curved knife at a ceremony not unlike the investiture of the accolade in the Middle Ages and celebrated with great festivities. In those epochs the navaja was in high esteem. Later on it, unjustly, got a bad reputation as a weapon for bellicose persons, for scoundrels, assassins, avengers (Fig. 1) and other categories of bad persons, though villainies could be performed with swords, daggers, pistols or rifles as well. More crimes have been performed by such weapons than by navajas. The province of Albacete, the homcland of the famous industry, was by no means worse than Murcia, Cuenca, Ciudad Real or any other region of the Peninsula in spite of its navajas. Charles Davillier, in his book Viaje por España (1874), says that Albacete is to Spain what Châtellerault is to France and Sheffield is to England. The navaja was the indispensable weapon to almost every Spaniard (Figs. 2-3). The long and sharp knife, in clasped shape, was worn in the sash, the belt, the waistcoat or even fastened with a cord or a chain to the button-hole of a jacket. At the beginnings of the 19th century Alexandre Louis Laborde in a book about the provinces of Spain, in 1826 said that in Albacete more than 200,000 navajas and pocket-knives were fabricátar? a year. In many little towns street- 
names still remind of the old workshops: calle de los navajeros, though these workshops long ago have come to an end (Fig. 4).

Diccionario de la lengua española (Real Academia Española) defines the navaja as a single-edged clasp-knife with the blade guarded between the shells of the handle when clasped. It can be defined-as some experts have done-as a single-edged clasp-knife with the pointed blade turning on a mechanism in the end of the hollowed handle by means of a rivet or bar and furnished with a solid spring which keeps the blade in fixed position when opened. This definition-very general indeedneeds more concrete details. The antique Spanish navaja was a large clasp-knife, as a rule single-edged with a sharp point. The more or less curved blade turned on its heel placed inside the shells of the handle. The mechanisms to secure the immobility when opened could be of various types (Figs. 5a-5b). The shape of the handle, terminating in a ferrule, followed that of the blade, for which reason it was more or less curved. The name navaja as signification of a knife is found rather early in medieval literary sources, and it may-according to some scholarshave its origin in the word novacula, which is found in literary sources already in 13 th century. On the other hand it can be documented ( $T e$ soro de la lengua castellana, tomo VI, Madrid 1902) from other sources that the word naballya was in general use among the Mozarabs already in 12 th and 13 th centuries. The medieval manuscripts of the LatinoArábigo and Arábigo-Latino dictionary from 13th century have the same name. Libro de Alexandre from 13 th century speaks about «good navajas» in the sense of good knives in general. The name navaja in the particular signification of clasping-weapon, here concerned, is known from the 16th century. A series of surnames and petnames exist, from the most different corners of the Peninsula, because this weapon on account of its usefulness had got such a wide distribution in all social classes: «abanico» (fan), «aifiler» (pin), «mondadientes» (tooth-pick) and numerous other designations.

The material used for the navajas in regard to handle could be wood of various kinds, iron, steel, brass, copper, silver, gold, turtle, horn from oxen and stags, bone, ivory or mother-of-pearl, according to the owner's taste, economy etc. Most important, however, was the material of the blade, e.g. the excellent steel from Mondragón, its quality, manufacture, temple etc. The testing of a navaja-blade generally was rather hard but this of course depended upon the forger and his personal skill. A highqualified and reputed navaja-smith in Albacete used to let his blades perforate a lo-cent mint without damaging the point of the blade, or else he would not sell it. The traditional blade was single-edged but generally with a fine yelman and frequently with a reinforced point. Navajas 
with double-edged blades exist and navajas with several kinds of blades for various purposes, are known, but these are more implements than weapons and do not belong to the special field of navajas. Characteristic for the navaja is its rather large size. The current length (in clasped shape) is about $18.24 \mathrm{~cm}$ but many specimens are Jonger. Those about $50-60 \mathrm{~cm}$ do not belong to the current types (Fig. 6). The super-long specimens are not weapons for practical use, but are generally of a more decorative character. Modern time navaja blades as a rule have a size of 10-14 cm. The shape of the blade almost always is curved-more or less-and the point is sharp (Fig. 7). The handles are hollow made of two shells to protect the blade when clasped, and even to protect the pocket or the sash of its owner. Generally the handles are decorated with some kind of ornaments, inlay of another material, decorative rivets, chiselled figures or flowers, painted designs or the like and the motives as a rule are of the current Mediterranean types in a style known from other parts of the Northern borders of the Mediterranean. Sometimes a style similar to the antique Hispano-Moresque designs is seen. The blades frequently have etched ornaments, e.g. scrolls, floral ornaments and now and then even figure-scenes are found (Fig. 25). Ornaments can even be painted with a dark red colour like ox-blood. Inlay with brass is frequent. Pierced ornaments are well-known. Parallel grooves and canals in the ricasso as a rule are of a decorative character. Inscriptions and mottos are frequent in the antique blades. Many inscriptions have disappeared in the run of time, others are only preserved in part but frequently so much of the text still exists that its contents can be understood. An interesting selection of mottos still exists and the texts let the navaja speak as an independent and individual person, the faithful servant of its owner, just like some of the sword-blades from the Middle Ages (pp. 18-19).

In regard to mechanisms for opening and clasping this weapon, various systems are found. Among the most frequent systems is that called "cierre de varilla» (Fig. 9) with a little, slightly curved bar more or less quadrangular inside the two shells of the handle. A variant of this system is the so-called «navaja de muelle» with spring and several teeth or notches on the heel of the blade, which produce a characteristic noise when the knife is opened. Widespread is the system «cierre de ventanas with an opening (a window) for fastening the teeth of the blade. More modern is the system with the little band or ring «anilla» which facilitates the opening of the blade. In modern time the most current system is that with the little tongue on the upper part of the bar with one or more folds. More rare is the system «cierre de virola giratoria» with its ring or bush on the upper part of the shaft. Further there exist 
systems of secret character «navajas de secreto» (Fig. 8), such as those "de reloj» with the little watch where it is necessary to place one of the «hands» of the reloj on the correct numeral in order to open the blade. But even navajas without lock mechanisms exist.

The multifarious character of the navaja made it a very useful weapon and at the same time an indispensable implement both in the field, for hunting, for slaughtering and for parting bread, meat, fruit etc. as well as many other kinds of domestic character. As a weapon for citizen and peasant during the Napoleonic wars on the Peninsula it played a most important part (Fig. 18).

The navaja is something special and characteristic to Spain and it has its origin in Spain. It is not before the 19th century that this type of weapon was dispersed to other parts of Europa and even to Asia (Fig. 10). But already in the 18th century it was manufactured-in its Spanish shape-_even in England, Germany, France, Portugal, Italy, Yugoslavia and Greece. In North Africa, however, it was unknown. In Hispano-America, not least in Mexico, it got a wide distribution mainly because many Spanish blade-smiths - particularly those from Toledoafter the decline of the art of blade-smithing in Spain tried to make their way for their art in the New World. On the Peninsula the use of the navaja was particularly concentrated in certain regions. In the NorthWestern parts this weapon was not fabricated and it is particularly in the Southern and Levantine regions that it is to be found as seen on the map figure 11. A special fame had the provinces of Albacete, Almería, Cuenca, Murcia, Toledo, Barcelona and Zaragoza, but navajas were made in several other regions too.

Though the word navaja in its signification of a knife in general occurs already in 12 th and 13 th centuries the characteristic weapon which in our days is known as navaja, apparently did not exist till the 16 th century (Figs. 13, 29, 30). At the end of the 16th century it had come to the New World. In Pueblo de los Angeles in Mexico there at that time was a flourishing manufacture of white arms, established by smiths coming from the Peninsula and working according to the manners and prescriptions from the old manufactures of Toledo. In the 17 th century the fabrication of the navajas in the Peninsula was remarkably increasing and the types entered a considerable development, not least in the second half of the century. From the end of this century fine pieces exist, signed by their masters and with «cierre de secreto», dedications and precious decoration. The 18 th century signifies a great development and interest particularly the second half of 18 th century and first half of 19 th century. This period represents the «golden age» of the navajas (Figs, 16-17). Many specimens from this time still exist. The navaja- 
makers were numerous almost to the end of this period. For various more or less well defined reasons their art, however, declined.

About 1732 the use of the name navaja is generalized in the legislation. During the last decades of the century the numerous condemnations of navajas, the prohibition of wearing navaja etc. meant a considerable decrease in the production. At the same time an enormous importation and competition from abroad of «Spanish» navajas from various countries started. This caused a further decline in the native fabrication. This characteristic Spanish «artesanía» little by little almost disappeared. The workshops were closed. The masters, whose knowledge had been handed down as secrets by oral traditions from father to son through centuries, died out. Persons capable to continue this noble art did not exist.

The 19 th century meant an increasing inundation of «Spanish» navajas, particularly from France. But in this century, especially in its first half, the navaja was a most necessary companion as an instrument of defense for every citizen and countryman in the guerrillas or in the street fights against the French enemies (Fig. 18). Contemporary illustrations and literature give an impression of the importance of this weapon just in those difficult periods. Foreign travellers who crossed Spain in the period between about 1820 and 1875 augmented in their books and articles the fame of this weapon and surrounded it with an almost romantic radiance as something typical Spanish. In regard to its social reputation it was considered a most important weapon and implement to its owner whether peasant, workman, bourgeois or hidalgo (Figs, 19-21). Particularly to the man in the street or the plain villager and countryman, who did not wear precious rapiers, elegant courte-épées or fine daggers, the navaja became at one time his weapon for defense and his indispensable implement in field, forest or house (Figs. 22-23). Literary sources about this plain but highly useful companion through the ages is more than scarce in contrast to sources and documentations dealing with the more aristocratic swords and rapiers. In the army it was never introduced and no regulations exist dealing with navajas. It was always a completely civilian weapon. (The navajas made by the Fábrica de Armas de Toledo in 1958 for the troops of parachutists is no real weapon but a multifacious knife with blade, saw, corc-screw, tin-opener etc.)

Since time of old fabrication, sale and right to possess weapons have been subjected to legislation. Very early in the Middle Ages the swordand knife-smiths were united in guilds with their special laws and regulations, with tests, proofs and stamps. The Fueros de Salamanca from 12 th century gave regulations in this regard. Early in 15 th century special rules for knife-smiths and their guilds existed in Barcelona, Va- 
lencia, Zaragoza and Gerona. This legislation can be followed through centuries. Carlos I in 1527 approved Ordenanzas for Sevilla and its sword-and knife-makers. But already the Catholic Kings at the end of 15 th century had approved such regulations. Carlos II in 1689 in Toledo gave Ordenanzas for the knife-smiths of the Imperial Town. But these regulations only mention knives, daggers and «otras armas blancas». They do not specify the categories of knives. It is not till 1732 that we find the navaja mentioned as an independent and individual weapon. The Royal Ordenanzas from 1749, 1751 and 1754 and later mention it among «otras armas cortas». In modern time the regulations from 1944 forbid the importation, sale and use etc. of navajas (as well as other categories of knives) which surpass certain measures (Figs. 24-25).

The navaja generally was worn in the sash, the belt, or waistcoat or in a cord or chain in the jacket. The general opinion, told by some Spanish and many foreign authors that the young Spanish girls («majas») used to wear a navaja in their garter doesn't hold good, though it cannot be denied that in a certain period and in certain regions it no doubt has been the case, e.g. during the Napoleonic wars. French soldiers from the troops of Napoleon, sometimes may have seen such knives in use during their ravage of the Peninsula. They contributed to spread such rumours when they returned to France, and even put them in circulation in other parts of Europe (Figs. 26-28).

Investigations in Spanish museums let us know how disregarded the navaja has always been among the arms' students. This simple, but interesting and beautiful weapon, has been considered a rather plain and folkloristic object, without interest or importance and for that reason it was either not exhibited in the museum show-cases or at least only put on bad or indifferent places. Several of the most important Spanish museums in regard to weapons do not even possess a navaja. Other museums only possess a few specimens. By the fate of irony the archaeological museum in Albacete, the once so important centre of fabrication, only possesses very few specimens in spite of traditions and former days rich fabrication in both province and capital of Albacete. But even in another important center for navajas, the Fábrica de Armas in Toledo, the investigator will look in vain for these weapons. Some interesting specimens are to be found in the museum of Cau Ferrat in Barcelona (Fig. 29) and an interesting series exist in Museo Arqueológico in Madrid, particularly some noteworthy specimens from 16th century (Figs. 30-31). In the same museum is a fine specimen from Albacete, dated 1789 and signed by the master. Of further interest is the little navaja with «cierre de secreto» with its little watch, where the movable hand must be placed at 3 o'clock in order to open the blade. 
In regard to stamps and signatures on Spanish and foreign navajas the plates on pages 52-54 give an impression. The specimens belong to the collection of the author.

Apart from the foreign travellers of 19 th century with their romantic descriptions of the Iberian Peninsula and its navajas, later time Spanish authors and poets in their works and poems have been laud in their praise of the navaja considering it a noble and beautiful weapon, worthy of laurels. Azorín, Pemán, Belmonte, García Lorca, Sandoval and many other well-known writers and poets laureate the navaja and Albacete (Fig. 32).

A. BR. H. 